\title{
ANÁLISE DAS DEMANDAS NACIONAL E INTERNACIONAL POR CAFÉ BRASILEIRO - PERÍODO DE 1961 A 2002
}

\section{Cesar De Castro Alves}

\author{
Engenheiro Agrônomo
}

Orientador: Prof. Dr. CARLOS JOSÉ CAETANO BACHA

Dissertação apresentada à Escola Superior de Agricultura "Luiz de Queiroz", Universidade de São Paulo, para obtenção do título de Mestre em Ciências, Área de Concentração: Economia Aplicada.

P I R A C I C A B A

Estado de São Paulo - Brasil

Novembro - 2004 


\section{ERRATA}

ALVES, C.C. Análise das demandas nacional e internacional por café brasileiro - período de 1961 a 2002

p. item

293.1 (Tabela 1)

$\begin{array}{lll}\text { linha } & \text { onde se lê } & \text { leia-se } \\ \text { sexta, sétima, oitava, nona e décima. } & 1975 & 1975 \\ & 21,4 \% & 26,3 \% \\ 6,2 \% & 7,6 \% \\ 9,0 \% & 11,0 \% \\ 5,0 \% & 6,2 \% \\ 1,9 \% & 2,3 \%\end{array}$

$29 \quad 3.1$ (Tabela 1)

sexta, sétima, oitava, nona e décima.

$\begin{array}{ll}1985 & 1985 \\ 33,7 \% & 25,9 \% \\ 11,4 \% & 8,8 \% \\ 10,5 \% & 8,1 \% \\ 8,5 \% & 6,6 \% \\ 9,4 \% & 7,2 \%\end{array}$

$29 \quad 3.1$ (Tabela 1)

sexta, sétima, oitava, nona e décima.

$\begin{array}{ll}1995 & 1995 \\ 14,5 \% & 17,1 \% \\ 5,6 \% & 6,7 \% \\ 10,4 \% & 12,3 \% \\ 2,8 \% & 3,3 \% \\ 7,3 \% & 8,7 \%\end{array}$

4.1.1 (Tabela 4)

sexta

6.361 .360

6.361 .306

$54 \quad 4.1 .1$

vigésima

... cada vez

mais

inelástico...

... cada vez

mais

elástico...

décima nona

Teste F
$\operatorname{Pr}>\mathrm{F}$
0,0005

Teste F

Pr $>$ F

$<0,0001$

$56 \quad 4.1 .2$ (Tabela 5)

vigésima segunda

Teste F
Pr $>$ F

Teste F

0,2608

$\mathrm{Pr}>\mathrm{F}$

0,2608

$56 \quad 4.1 .2$

vigésima oitava

...diminui...

0,0001

$\begin{array}{lll}59 & 4.1 .3(\text { Tabela } 6) & \text { nona } \\ 67 & 4.2(\text { Tabela } 9) & \text { décima primeira }\end{array}$

$5.568,4$

...mantém-se constante...
674.2 (Tabela 9$)$

décima primeira

$\ln \mathrm{Cpc}$

$5.565,4$

$\mathrm{Cpc}$ 
Dados Internacionais de Catalogação na Publicação (CIP) DIVISĀO DE BIBLIOTECAE DOCUMENTAÇĀO - ESALQ/USP

\author{
Alves, Cesar de Castro \\ Análise das demandas nacional e internacional por café brasileiro - periodo de 1961 a \\ 2002 / Cesar de Castro Alves. - - Piracicaba, 2004. \\ $124 \mathrm{p}$. \\ Dissertação (Mestrado) - - Escola Superior de Agricultura Luiz de Queiroz, 2004. \\ Bibliografia. \\ 1. Análise de regressão 2. Café 3. Econometria 4. Demanda 5. Exportação 6. Mercado \\ externo 7. Mercado interno 8. Preço 9 Renda I. Título
}

$\operatorname{CDD} 338.17373$

Permituda a copha total o u parcial deste dotumento o s de que citada a fonte 0 autar 
Dedico este trabalho aos meus maiores exemplos: meus pais, Fernando e Sônia. 


\section{AGRADECIMENTOS}

As pessoas que aqui agradeço, estão relacionadas de acordo o momento em que tiveram importância nesta etapa da minha vida. Não os relaciono pela magnitude das suas contribuições, pois eu poderia estar sendo injusto os classificando inadequadamente, afinal muitos ainda continuam a me apoiar.

Agradeço com muita dificuldade em encontrar palavras que traduzam minha gratidão, aos meus pais e irmãos, Fernando, Sônia, Malvina e Marcelo, pela confiança dedicada a mim desde a pré-escola, pelas oportunidades concedidas, apoio nos momentos delicados e pelo carinho eterno.

Aos professores que em São Paulo, antes do início das minhas atividades na ESALQ, me propiciaram grandes oportunidades e me orientaram com muita dedicação. Agradeço imensamente aos professores José Roberto Mendonça de Barros, Guilherme Leite da Silva Dias e Maria Sylvia Macchione Saes.

Ao professor Carlos José Caetano Bacha, que com sabedoria, foi extremamente fiel como orientador. Estou muito grato ao professor Carlos Bacha, pelo aprendizado direto e indireto envolvido neste trabalho sério que fizemos juntos.

Agradeço também ao amigo e professor Alexandre Lahóz Mendonça de Barros, pelo apoio e crédito concedidos a mim, sempre.

Ao amigo Alexandre Chibebe Nicolella que nunca mediu esforços em me ajudar.

Ao professor Pedro Valentim Marques, pelos votos de confiança e oportunidades na minha passagem pelo Programa de Educação Continuada em Economia e Gestão de Empresas (PECEGE). 
Aos professores Roberto Arruda de Souza Lima, Márcia Azanha Ferraz Dias de Moraes e Mirian Rumenos Piedade Bacchi, pelas valiosas contribuições no seminário e no meu exame de qualificação.

Agradeço à querida Maielli, pelo seu carinho e dedicação à pós-graduação e por estar sempre cuidando dos alunos esquecidos.

À professora Adeli Bacchi Dias de Moraes e Silva pelas contribuições na elaboração do summary.

E finalmente e não menos importante, agradeço aos eternos amigos que levarei por toda vida, sempre presente nos momentos mais importantes: Gustavo Fisher Sbrissia, Elisson Augusto Pires de Andrade (Tiziu), Alexandre Nunes de Almeida (Chefão) e Alexandre Lopes Gomes (Jiló). Muito obrigado a todos vocês. 


\section{SUMÁRIO}

Página

LISTA DE FIGURAS …………………………..................................... viii

LISTA DE QUADROS .......................................................................... ix

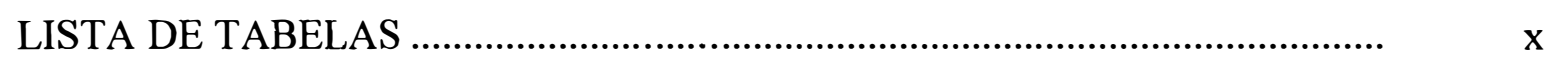

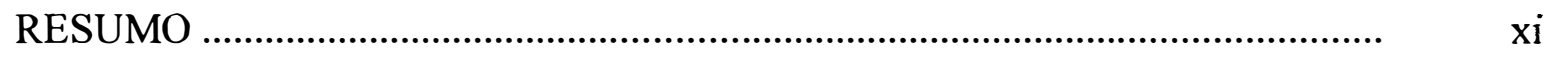

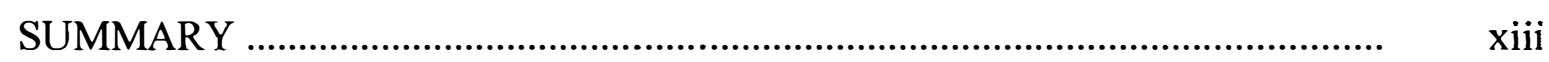

1 INTRODUÇÃO ............................................................................ 1

$1.1 \quad$ O problema em análise ........................................................................

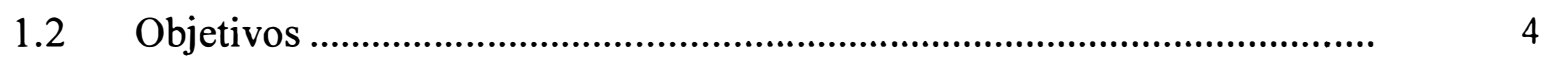

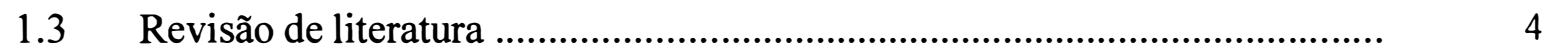

1.3.1 Literatura sobre a demanda externa por café brasileiro ................................ 5

1.3.2 Literatura sobre a demanda interna de café no Brasil ...................................

1.3.3 Literatura sobre equações de determinação de preços .................................. 11

1.3.4 Avaliação global da literatura existente e a contribuição dessa dissertação $\quad 11$

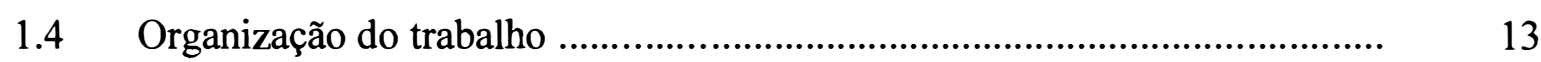

2 MODELOS ECONOMÉTRICOS E PROCEDIMENTOS PARA ESTIMAR A EQUAÇÃO DE DEMANDA ….......................................... 14

2.1 Modelos econométricos ......................................................................... 14

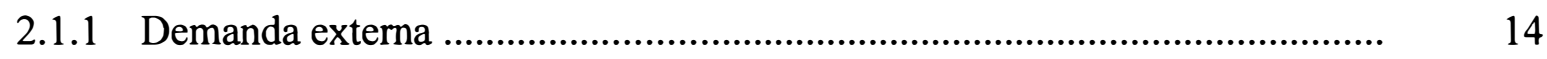

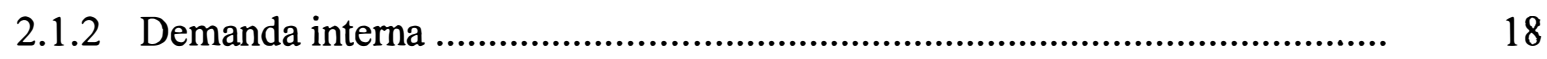

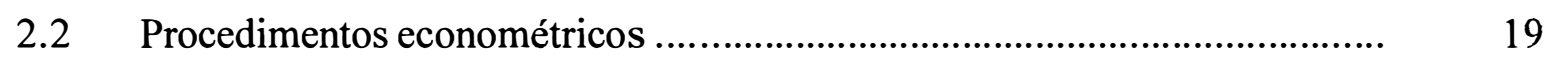

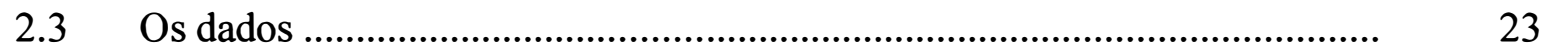


3 ANÁLISE DOS PRINCIPAIS MERCADOS CONSUMIDORES DE 25 CAFÉ DO BRASIL

3.1 Evolução das exportações brasileiras de café .................................................... 25

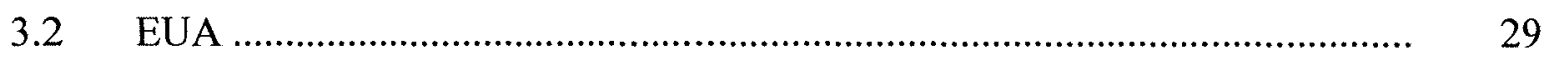

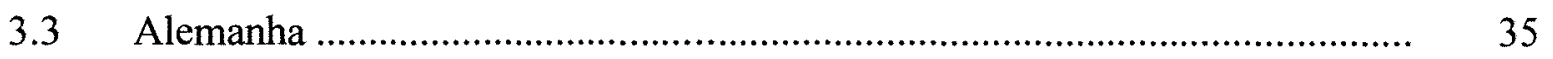

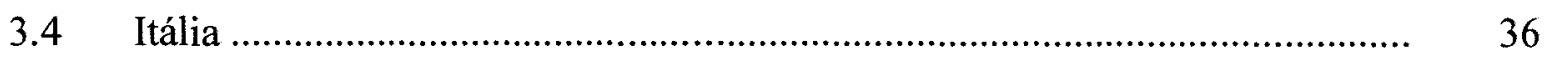

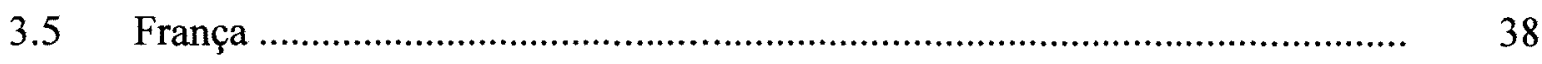

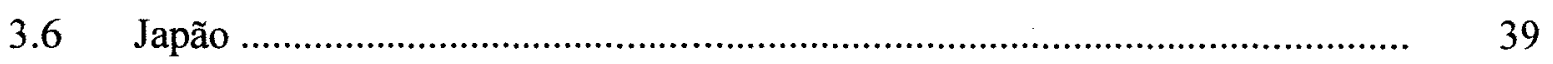

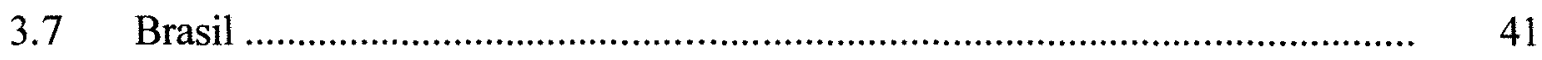

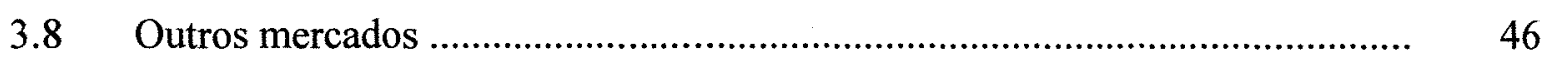

$4 \quad$ RESULTADOS E DISCUSS ÃO _............................................................. 47

4.1 Análise da demanda externa ........................................................................ 47

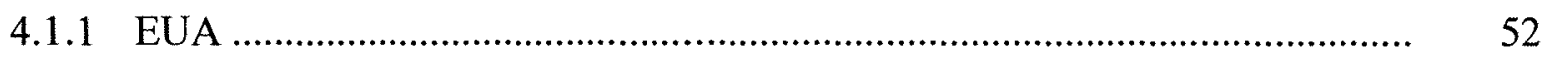

4.1.2 Alemanha ....................................................................................... 55

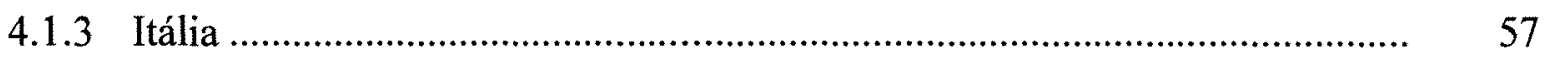

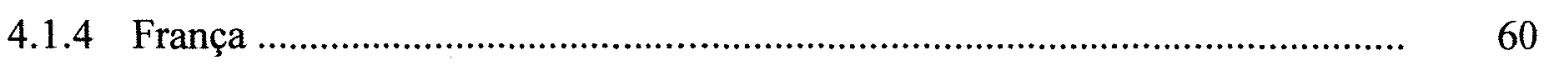

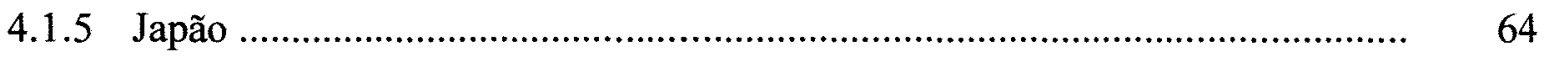

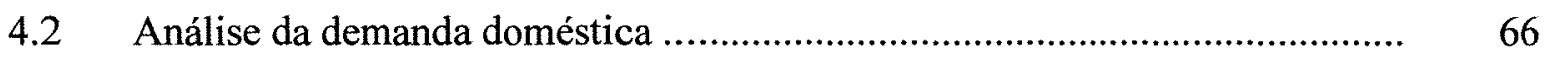

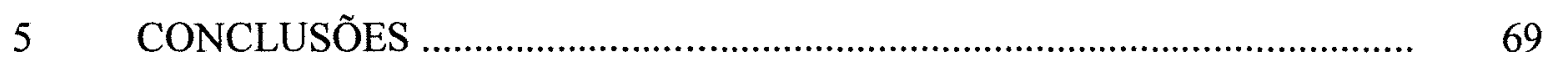

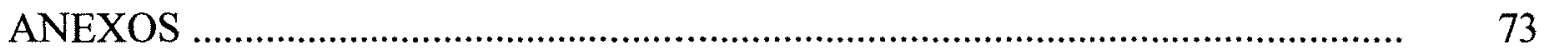

REFERÊNCIAS BIBLIOGRÁFICAS _.......................................................... 121 


\section{LISTA DE FIGURAS}

Página

$1 \quad$ Exportações brasileiras de café verde ................................................ 26

2 Exportações mundiais e brasileiras de café verde (em milhões de sacas de $60 \mathrm{~kg}$ )

3 Participação das exportações brasileiras nas exportações totais de café verde

4 Exportações brasileiras de café verde para os EUA

5 Participação das exportações brasileiras nas importações totais de café

verde (market share) em cinco mercados consumidores, em percentual

6 Exportações brasileiras de café verde para a Alemanha ........................

$7 \quad$ Exportações brasileiras de café verde para a Itália ............................... 37

$8 \quad$ Exportações brasileiras de café verde para a França .............................. 38

9 Exportações brasileiras de café verde para o Japão ................................ 40

10 Consumo brasileiro de café verde (total e per capita) ............................ 42 


\section{LISTA DE QUADROS}

\section{Página}

1 Resumo das elasticidades-preço e renda (Ep e Er) obtidas nos principais trabalhos sobre a demanda norte-americana de café

2 Modelos de regressão múltipla utilizados nas estimativas da demanda pelo café verde brasileiro nos mercados consumidores estudados

3 Modelos de regressão múltipla utilizados nas estimativas da demanda interna pelo café verde brasileiro

4 Modelos de regressão múltipla utilizados nas estimativas da demanda interna pelo café verde brasileiro, considerando quebras de tendência ..

5 Elasticidades preço e renda obtidas nos modelos selecionados como melhores estimativas para os mercados estrangeiros estudados (período de 1962 a 2002) 


\section{LISTA DE TABELAS}

Página

1 Participação dos principais mercados consumidores nas exportações brasileiras de café verde (em percentual) ............................................... 29

2 Consumo de café nos principais mercados consumidores - ano safra (em milhões de sacas de $60 \mathrm{~kg}$ )

3 Consumo per capita de café verde nos principais mercados consumidores - ano safra (em $\mathrm{kg}$ de café verde/hab/ano)

$4 \quad$ Resultado dos modelos de melhor ajuste nas regressões estimadas para a demanda norte-americana pelo café brasileiro

5 Resultado dos modelos de melhor ajuste nas regressões estimadas para a demanda alemã pelo café brasileiro

6 Resultado dos modelos de melhor ajuste nas regressões estimadas para a demanda italiana pelo café brasileiro

7 Resultado dos modelos de melhor ajuste nas regressões estimadas para a demanda francesa pelo café brasileiro

8 Resultado dos modelos de melhor ajuste nas regressões estimadas para a demanda japonesa pelo café brasileiro

9 Resultado dos modelos de melhor ajuste nas regressões estimadas para a demanda doméstica pelo café brasileiro 


\title{
ANÁLISE DAS DEMANDAS NACIONAL E INTERNACIONAL POR CAFÉ BRASILEIRO - PERÍODO DE 1961 A 2002
}

\author{
Autor: CESAR DE CASTRO ALVES \\ Orientador: Prof. Dr. CARLOS JOSÉ CAETANO BACHA
}

\section{RESUMO}

Diante da necessidade de se conhecer as elasticidades preço e renda em mercados específicos sem generalizar a demanda global por café brasileiro, o presente trabalho se propôs a analisar a demanda por café brasileiro e verificar quais foram seus determinantes nos mercados interno e externo, no período de 1961 a 2002. O estudo inicialmente preocupou-se em explorar o market share em cada mercado estrangeiro de modo a associá-lo com os resultados econométricos. Para a análise, foram considerados seis mercados consumidores tradicionais do café verde brasileiro: EUA, Alemanha, Itália, França, Japão e o próprio mercado interno, que representa a demanda da indústria nacional de torrefação. Cada mercado estrangeiro foi estudado separadamente e submetido à análise de regressão, utilizando o método dos mínimos quadrados ordinários. Foram estimados 44 modelos econométricos especificados com alternativas de bebidas que poderiam estar apresentando substituição com o café brasileiro nos mercados estrangeiros. Os modelos estimados foram divididos em modelos de consumo e 
renda globais e modelos em termos per capita. Selecionou-se, a partir dos maiores níveis de significância, face às equações estimadas, aquela que melhor se ajustou aos dados em cada mercado. $\mathrm{O}$ modelo selecionado foi re-estimado considerando duas subdivisões em períodos, de modo a captar as mudanças nas elasticidades preço e renda que possam ter ocorrido ao longo do tempo. Assim, para o modelo selecionado há estimativas para os períodos de 1961 a 2002, 1970 a 2002 e 1980 a 2002. Para a demanda interna, dois modelos em termos per capita foram estimados para os períodos citados.

Em todos os períodos considerados no presente trabalho (de 1961 a 2002, de 1970 a 2002 e de 1980 a 2002) e em todos os mercados, o café é um produto de demanda inelástica a preço e essa inelasticidade pouco tem se alterado ao longo do tempo.

Os resultados da pesquisa indicaram que na Alemanha, Itália, Japão e no mercado doméstico ainda é possível esperar novos aumentos da demanda de café verde na medida em que essas economias cresçam. Os mercados norte-americano e francês não são promissores para as exportações de café verde, sendo necessário a inserção de uma outra alternativa de café a ser exportado, com maior diferenciação do produto nesses países. 


\title{
ANALYSIS OF THE INTERNATIONAL AND DOMESTIC DEMAND FOR BRAZILIAN GREEN COFFEE - TIME PERIOD FROM 1961 TO 2002
}

\author{
Author: CESAR DE CASTRO ALVES \\ Adviser: Prof. Dr. CARLOS JOSÉ CAETANO BACHA
}

\section{SUMMARY}

The objective of this work is to evaluate the international and domestic demand for Brazilian green coffee. Time period from 1961 to 2002 is taken into consideration. This work tries to know price and income elasticity in specific markets rather then estimating global demand for Brazilian coffee. We analyze Brazil's market share in each foreign market in order to associate it with our econometric results. The analysis take into consideration six traditional Brazilian green coffee consumers: the United States of America, Germany, Italy, France, Japan and the Brazilian own domestic market, which represents the domestic roasting industry's demand. Each foreign market was studied separately and submitted to a regression analysis, using the ordinary least square method. Forty-four alternative models, considering different substitute beverage which could replaced Brazilian coffee at international markets, were estimated. The estimated models were divided in global consumption and income-based models, and in per capita valuebased models. Considering the largest significant levels of estimated parameters, the best 
model for each market was selected. The latter was re-estimated considering two subdivisions of period, which made possible to detect price and income elasticity changes during the time. At the end, regressions were run for the following periods: 1961 to 2002; 1970 to 2002 and 1980 to 2002. It was estimated two per capita value-based models for the domestic demand and they were also submitted to the same period divisions.

For all the periods considered in the present work (from 1961 to 2002, from 1970 to 2002 and from 1980 to 2002) and for all markets analyzed, coffee has inelastic price demand and this inelasticity has changed little along the time.

Our findings show that in Germany, Italy, Japan and in the Brazilian domestic market is still possible to have an increase of the green coffee demand since their economies grow. US and French markets are not promising in regard to increases of green coffee export. For these markets, a differentiated coffee need to be offered in order to enlarge Brazil's coffee exports. 


\section{INTRODUÇÃo}

\subsection{O problema em análise}

O café sempre foi um produto com importância expressiva na geração de divisas para o Brasil. O seu cultivo tem destaque pelo potencial na geração de empregos, aptidão climática de inúmeras regiões na obtenção de bebidas finas e desenvolvimento regional. Muito embora haja razões suficientes que apontem a importância da cafeicultura, este setor tem sido penalizado pelas políticas mal conduzidas ao longo do tempo, que levaram à perda de participação da bebida brasileira no comércio internacional e prejudicaram de diferentes maneiras vários agentes envolvidos no sistema agroindustrial do café.

De modo a contribuir para o melhor entendimento do agribusiness do café, pretende-se explorar alguns pontos importantes na comercialização do café, dando destaque à demanda por esse produto.

Dentro deste contexto, o propósito deste trabalho é avaliar as mudanças que vêm ocorrendo ao longo do tempo nas demandas nacional e internacional pelo café brasileiro. O período em análise é de 1961 a 2002. Este período foi selecionado pela disponibilidade de dados confiáveis para análise.

O Brasil já deteve, no início do século XX, cerca de $75 \%$ das exportações mundiais de café. Esta percentagem caiu ao longo do tempo, sendo que em 2001 (início do século XXI) o Brasil foi responsável por cerca de $25 \%$ das exportações mundiais de café.

A cafeicultura brasileira apresenta três tipos de comportamentos cíclicos dos preços e/ou produção: o ciclo plurianual, o ciclo bienal e o ciclo intra-anual (o qual implica variação sazonal de preços). 
$\mathrm{Na}$ entrada do século XXI tem-se observado uma elevada oferta de café nos mercados internacional e interno, devido às características cíclicas da cultura do cafeeiro.

A oferta é afetada pelos ciclos de produção. Por questões fisiológicas, o cafeeiro demanda certo tempo entre as fases de plantio e produção, o que leva a comportamentos distintos de preços e produção ao longo dos anos. Esses comportamentos formam os ciclos plurianuais de preços e produção. Tais ciclos ocorrem quando uma época de produções decrescentes, com respectiva redução de estoques e com queda na oferta internacional, acaba por gerar aumentos na cotação do produto. Estes aumentos incentivam novos plantios de cafeeiros, o que eleva a quantidade produzida em médio prazo. Este aumento de produção, por sua vez, gera estoques crescentes, os quais conduzem à queda de preços. Diante desse novo cenário, os produtores reduzem os tratos culturais em suas lavouras, tentando enxugar custos de produção. No entanto, essa medida acaba por reduzir as produtividades médias. Nessa fase de preços baixos, há situações não atípicas de erradicação dos cafezais, as quais conduzem à redução da produção e dos estoques do produto, dando início a um novo ciclo de preço e produção. Isto caracteriza a atividade cafeicultora no Brasil.

Esses ciclos de preços e produção se tornam mais intensos devido ao fato das estimativas dominantes da demanda externa pelo café brasileiro indicarem que ela é inelástica a variações de preços. Isto, por sua vez, implicou políticas de defesa do preço do café baseadas na contenção das exportações. Estas políticas já não são mais possíveis de serem conduzidas isoladamente pelo Brasil.

Os ciclos plurianuais de preço e produção do café afetam, negativamente, o consumo de café. Em uma fase de alta de preços haverá a diminuição do seu consumo, mesmo a demanda sendo inelástica, havendo substituição do café por outras bebidas bastante práticas quanto ao consumo e sem estarem sujeitas a ciclos de preço e produção. Entre essas bebidas estão os refrigerantes.

É possivel ofertar refrigerantes, por exemplo, sem quaisquer restrições fisiológicas ou climáticas inerentes ao processo produtivo. E uma vez alterado o padrão de consumo (troca de café por refrigerante) esse se mantêm ao longo do tempo. Isto explica a estagnação ou decadência do consumo per capita de café em alguns países. 
Os ciclos de preços também levam ao surgimento no mercado de novos produtores. $\mathrm{Na}$ fase de alta dos preços, os produtores de certos países aumentam sua produção e acabam por mantê-las em níveis altos nas fases de baixa de preços. Com isso, surgem alterações nas participações dos países no ranking de maiores produtores de café.

Com relação à participação brasileira nas exportações mundiais de café é observado que o país tem perdido mercado para outros países produtores ao longo do tempo. Esta perda deveu-se, principalmente às políticas de regulamentação do Sistema Agroindustrial (SAG) do Café, em especial, ao plano de retenção de estoques de café no Brasil com objetivo de sustentação de preços. Esta última causou uma perda notável de market share, aliado ao aumento de produção de outros países, como o Vietnã. Tal estratégia, preocupada em restringir a quantidade, inibiu ações em busca de novos mercados e de "nichos" dentro dos mercados tradicionais.

Concomitantemente à queda das participações do Brasil nas exportações mundiais de café, houve o aumento da demanda nacional de café. O mercado interno já é o segundo maior consumidor de café brasileiro.

Há uma ampla literatura sobre demanda de café brasileiro. No entanto, essa literatura restringiu-se a analisar, principalmente, a demanda externa por café brasileiro como um todo, não observando como essa demanda difere de país a país.

O conhecimento mais detalhado dos principais determinantes da demanda de café nos principais mercados consumidores permitirá a sugestão de estratégias diferenciaàas visando à recuperação ou ampliação das exportações de café. Isto será melhor do que estratégias genéricas e que possam falhar por não considerarem distintas características dos diferentes mercados. 


\subsection{Objetivos}

O objetivo geral deste trabalho é analisar a demanda por café brasileiro nos mercados interno e externo, estimando equações de demanda e verificando os principais determinantes destas demandas. Para tanto, os principais países compradores de café brasileiro, inclusive o Brasil, são considerados de maneira individual e suas equações de demanda são estimadas.

Os objetivos específicos são:

1) Caracterizar os principais mercados consumidores de café brasileiro, inclusive o mercado doméstico;

2) Definir e estimar equações de demanda de café nesses mercados.

O período de tempo considerado na análise é o de 1961 a 2002, para o qual há séries consistentes de dados necessários a estimar as equações de demanda.

\subsection{Revisão de literatura}

Diversos trabalhos já foram realizados na tentativa de se estimar a demanda por café brasileiro. O resultado final da maioria dos estudos foi, quase sempre, sugerir políticas mais racionais para o setor, através do delineamento de esquemas de subsídio, tributação, apoio ou financiamento da produção e comercialização. Essas sugestões de políticas são apoiadas em estudos de elasticidades da demanda, variações de preços, renda, preferências do consumidor e principalmente na estrutura de demanda do café.

Essa literatura pode ser dividida em três grupos: trabalhos que analisaram a demanda externa por café brasileiro, trabalhos que avaliaram a demanda doméstica por café e trabalhos que analisaram os fatores que afetam os preços do café. Os Quadros 6, 7 e 8, apresentados no anexo A, resumem, com detalhes, esses trabalhos. A seguir, comentam-se alguns aspectos desses trabalhos, em especial o período de tempo que consideraram e suas constatações sobre elasticidades-preço e renda da demanda de café. 


\subsubsection{Literatura sobre a demanda externa por café brasileiro}

O trabalho pioneiro de estimativa da demanda externa de café brasileiro parece ter sido o de Kingston (1939). Ele analisou uma série temporal de apenas onze anos (19271937), e fez uso de dois modelos: um linear e um marshalliano. Ele considerou apenas o preço do café e o tempo como variáveis independentes nos modelos sugeridos e encontrou relações negativas entre a demanda mundial pelo café brasileiro e os preços do café tipo Santos 4. A elasticidade-preço encontrada, doravante denominada Ep, foi da ordem de $-0,14$.

Após o estudo de Kingston, outros trabalhos foram realizados para se estimar a demanda de café. Estes trabalhos avaliaram a demanda global e/ou a demanda por café brasileiro (Quadro 6, no anexo A).

Dentre os trabalhos que focaram especificamente a demanda mundial pelo café brasileiro, assim como o trabalho de Kingston, pode-se destacar as contribuições de Finageiv (1976), Tamaki \& Larson (1982), Almeida (1993) e Alvim et al. (2003).

Segundo Finageiv (1976), até o momento de seu estudo pouco ou nada se sabia acerca do que ocorria com o contínuo decréscimo da participação brasileira no mercado mundial de café. Ao estudar esta perda de participação, pode-se concluir que se tornando menor a parcela brasileira no abastecimento do mercado mundial de café, a elasticidadepreço da demanda de exportação brasileira de café aumenta. A Ep global para a demanda de café foi de $-0,11$, indicando que para uma variação de $10 \%$ no preço do produto espera-se, ceteris paribus, uma variação em sentido contrário de $1,1 \%$ na quantidade total exportada de todas as origens (demanda total mundial). Ele estima ainda que a Ep da demanda de exportação de café brasileiro é igual a $-0,46$.

Tamaki \& Larson (1982) estimaram a demanda em nível do consumidor (café em pó e solúvel) pelo café brasileiro em sete países, em diversos períodos de tempo. Foram consideradas séries temporais curtas, porém, suficientes para estimação pelo método dos mínimos quadrados ordinários (MQO). Eles observaram sempre elasticidades-preço negativas nos mercados estudados, porém, a demanda torna-se menos elástica à medida que o consumo per capita aumenta. Com relação à elasticidade-renda (Er), os autores 
afirmam, com segurança, que o café solúvel era um bem normal, tendo sido observados valores relativamente altos de Er. Para a demanda por café em pó, foi observado que este era um bem inferior em alguns países.

Ao se analisar apenas o período de 1970 a 1989, Almeida (1993) obteve resultados diferentes para as elasticidades-preço e renda da demanda por café brasileiro em relação aos autores citados anteriormente.

Almeida (1993) estimou equações de demanda global pelo café brasileiro através do método dos mínimos quadrados ordinários em séries temporais anuais. $\mathrm{O}$ autor obteve elasticidade-preço igual a $-1,54$, o levando a concluir que a demanda externa pelo café brasileiro era preço-elástica. Foi observado, ainda, elasticidade-renda igual a 2,43, o que permite dizer que o café brasileiro era um bem normal, com demanda do tipo renda elástica, para o período estudado. Há que se ressaltar, no entanto, que o coeficiente de determinação obtido na análise de regressão feita por Almeida (1993) indica que apenas $50,93 \%$ das variações observadas na quantidade demandada de café do Brasil podem ser explicadas por variações nas respectivas variáveis independentes incluídas no modelo. $\mathrm{O}$ autor também ressalta que seus resultados obtidos para a elasticidade-preço da demanda podem estar refletindo o fato de terem sido utilizados preços relativos para as exportações brasileiras, e não preços em termos absolutos, como sugerem alguns trabalhos. É importante destacar, ainda, que a análise de correlação linear entre as variáveis incluídas na equação estrutural de demanda indicou a presença de multicolinearidade alta entre as variáveis independentes renda e tempo. $\mathrm{O}$ autor justifica que:

"Mesmo tendo-se conhecimento de que a multicolinearidade aumenta a variância dos estimadores, preferiu-se manter a equação em sua forma original, tendo em vista que a literatura especializada informa que a omissão de uma variável importante introduz tendenciosidade nos parâmetros estimados" (Almeida, 1993, p.44). 
Destaca-se ainda que outras variáveis não incluídas no modelo são de suma importância na determinação da demanda internacional pelo café brasileiro, e que, por esta razão, não devem ser negligenciadas.

Alvim et al. (2003) analisou a demanda mundial por café brasileiro de 1980 a 2001 e constatou que a elasticidade-preço da demanda variou de $-0,953$ a $-1,16$ e a elasticidade-renda variou de 0,42 a 0,519 , segundo o modelo estimado.

Os resultados de Almeida (1993) e Alvim et al. (2003) quando comparados com os de Kingston (1939), Finageiv (1976) e Tamaki \& Larson (1982) indicaram aumento, ao longo do século passado do valor absoluto, da elasticidade-preço da demanda de café. Isso pode estar ocorrendo devido a:

i) A demanda de café nos principais países consumidores está se tornando menos inelástica;

ii) Novos países consumidores de café brasileiro têm elasticidade-preço maior do que os países tradicionais;

iii) Há mudança de importância dos países na compra de café brasileiro, aumentando a importância dos que têm maior elasticidade-preço.

Infelizmente, nenhuma dessas possibilidades foi ainda avaliada na literatura existente. A maioria dos estudos tem avaliado a demanda norte-americana por café.

Os estudos realizados sobre a demanda norte-americana de café avaliaram a demanda total (importação total de cafés pelos EUA) ou especialmente a demanda pelo café brasileiro (importação de café brasileiro pelos EUA). Entre esses estudos, citam-se os trabalhos de Delfim Netto (1955), Daly (1958), Paniago (1963), Delfim Netto \& Pinto (1965), Bacha (1968) ${ }^{1}$, citado por Barbosa (1985), Abaelu \& Manderscheid (1968), Viacava (1973) e Viana et al. (2003).

Esses estudos utilizaram modelos e dados distintos, tal como se observa no Quadro 1. As elasticidades-preço e renda encontradas nestes trabalhos estão colocadas no mencionado Quadro.

\footnotetext{
${ }^{1}$ BACHA, E.L. An econometric model for the world coffee market: the impact of Brazilian price policy. New Haven, 1968. 240p. Tese (Doutorado) - Yale University.
} 


\begin{tabular}{|c|c|c|c|c|}
\hline Autor (ano) & Período & Demanda & Ep & Er \\
\hline $\begin{array}{l}\text { Delfim Netto } \\
\text { (1955) }\end{array}$ & $1925-1952$ & $\begin{array}{l}\text { Norte-americana } \\
\text { pelo café mundial }\end{array}$ & $-0,10$ à $-0,38$ & 0,68 a 0,41 \\
\hline Daly (1958) & $\begin{array}{l}1922-1941 \\
1947-1957\end{array}$ & $\begin{array}{l}\text { Norte-americana } \\
\text { pelo café mundial }\end{array}$ & $\begin{array}{l}E \mathrm{E}_{1 \text { (periodo 1) }}=-0,26 \\
E \mathrm{p}_{2 \text { (periodo 2) }}=-0,30\end{array}$ & $\begin{array}{l}E r_{1}=0,23 \\
E r_{2}=0,10\end{array}$ \\
\hline Paniago (1963) & $1918-1961$ & $\begin{array}{l}\text { Norte-americana } \\
\text { pelo café mundial }\end{array}$ & $-0,11$ & 0,27 \\
\hline $\begin{array}{l}\text { Delfim Netto } \\
\& \text { Pinto (1965) }\end{array}$ & $1954-1965$ & $\begin{array}{l}\text { Norte-americana } \\
\text { pelo café mundial }\end{array}$ & $-0,4$ & Não calcula \\
\hline Bacha (1968) & $1951-1965$ & $\begin{array}{l}\text { Norte-americana } \\
\text { pelo café mundial. }\end{array}$ & $\begin{array}{l}-0,15 \text { (pó) e }-1,13 \\
\text { (solúvel) ou }-0,59 \\
\text { (pó) e }-1,059 \\
\text { (solúvel) }\end{array}$ & $\begin{array}{ll}0,35 & \text { (pó) } \\
\text { ou } & 0,57 \\
\text { (pó) } & \end{array}$ \\
\hline $\begin{array}{l}\text { Abaelu \& } \\
\text { Manderscheid } \\
\text { (1968) }\end{array}$ & 1953-1961 & $\begin{array}{l}\text { Norte-americana } \\
\text { pelo café brasileiro }\end{array}$ & $-0,21$ & $-0,89$ \\
\hline $\begin{array}{l}\text { Viana et al. } \\
(2003)\end{array}$ & $1975-2000$ & $\begin{array}{l}\text { Norte-americana } \\
\text { pelo café de } \\
\text { diversas origens }\end{array}$ & $-0,017$ & 0,149 \\
\hline
\end{tabular}

Quadro 1 - Resumo das elasticidades-preço e renda (Ep e Er) obtidas nos principais trabalhos sobre a demanda norte-americana de café

Os trabalhos apresentados no Quadro 1 são consistentes em ressaltar que a demanda norte-americana global por café e especificamente a demanda norte-americana por café brasileiro são inelásticas a preço. No entanto, não há similaridade nos resultados sobre a dimensão da elasticidade-preço.

É importante ressaltar que, exceto o trabalho de Viana et al. (2003), os trabalhos apresentados no Quadro 1 só analisaram o consumo de café até a década de 1960, enquanto que os trabalhos de Finageiv (1976) e Tamaki \& Larson (1982) incluem parte da década de 1970. Outro aspecto importante, evidenciado no Quadro 1, é que a elasticidade-renda da demanda norte-americana por café (de todas as origens) foi positiva, mas menor do que 1 . No entanto, a demanda norte-americana por café brasileiro (trabalho de Abaelu \& Manderscheid, 1968) evidenciou elasticidade-renda negativa. Ou seja, o café brasileiro foi um bem inferior para o consumidor norte-americano, mas não o café de outras origens. 
A mais recente estimativa sobre a demanda externa por café brasileiro e de outras origens pode ser encontrada no trabalho de Viana et al. (2003). Foi estimada a demanda por diferentes cafés nos principais mercados consumidores para o período de 1975 a 2000. Esse autor utiliza a metodologia de mínimos quadrados ordinários em modelos de regressão múltipla duplo-logaritmo, com as variáveis explicativas sendo preço do café (em determinado país), renda e a variável dependente defasada. De modo geral, as elasticidades-preço observadas pelo autor concordam com os resultados já obtidos em outros trabalhos, ou seja, a demanda por café é preço-inelástica. Contudo, a dimensão da elasticidade-preço é variável, tendo sido observado elasticidades-preço entre - 0,02 e 0,56 respectivamente para os mercados norte-americano e italiano. Entretanto, foram observadas para Japão e Holanda elasticidades-preço positivas, ou seja, com sinais contrários ao que normalmente é indicado pela teoria econômica. Particularmente, a Holanda mostrou sinais contrários à teoria para elasticidade-preço e renda. As elasticidades-renda obtidas variaram entre $-0,35$ e 1,48 nos mercados estudados.

Silva \& Maia (2003) utilizaram um sistema de equações para verificar o impacto de choques na renda externa, taxa de câmbio real efetiva e preço do café de exportação no valor das exportaç̃es de café. Para tanto, foi utilizado o período de 1961 a 2001 com dados anuais transformados em logaritmos. Tendo sido observado que as variáveis são co-integradas ou apresentam relação de equilíbrio no longo prazo, utilizou-se um modelo VAR (1) submetido a correção de erros utilizando o teste de raiz unitária (Augmented Dikey-Fuller) e teste de co-integração (Johansen-Juselius). No trabalho de Silva \& Maia (2003) não foram calculadas as elasticidades-preço e renda da demanda externa por café brasileiro.

\subsubsection{Literatura sobre a demanda interna de café no Brasil}

O número de trabalhos analisando a demanda doméstica por café no Brasil é bem menor do que os que analisaram a demanda externa por café brasileiro. Destacam-se os trabalhos de Carvalho (1974), Marques (1984) e Costa \& Silva (2003) apresentados resumidamente no Quadro 7, no anexo A. 
Os trabalhos estimaram funções de demanda interna de café ao analisar diferentes períodos, através da metodologia de mínimos quadrados ordinários. Utilizando séries temporais anuais per capita, eles sugerem modelos de regressão múltipla e observam razoáveis níveis de significância para as estimativas de consumo interno.

Carvalho (1974), considerando o período de 1964 a 1971, sugere que o consumo per capita de café no Brasil seja explicado por nove variáveis (ver o Quadro 7). O grau de significância dos parâmetros estimados variou de 1 a $10 \%$, o coeficiente de determinação foi de $64 \%$ e o teste $\mathrm{F}$ foi significativo a $1 \%$. Dos resultados obtidos, podese concluir que a demanda interna é preço-inelástica $(\mathrm{Ep}=-0,13)$ e renda-inelástica $(\mathrm{Er}=$ $0,26)$ para o modelo linear utilizado sem transformações logarítmicas dos dados.

Ao analisar o período de 1960 a 1981, Marques (1984) utilizou modelos de regressão múltipla com dados em termos per capita. A autora estimou a demanda interna per capita de café torrado e moído utilizando as variáveis que estão descritas no Quadro 7, em anexo. Foram observados, de maneira geral, bons níveis de significância nas análises realizadas. A elasticidade-preço média calculada para dois períodos (1960 a 1971 e 1972 a 1981) foi de $-0,059$. A variável renda real per capita utilizada como uma das variáveis explicativas não apresentou bom nível de significância estatística nas regressões.

Costa \& Silva (2003), analisando o período de 1970 a 2000, estimaram a demanda interna por café arábica pela indústria de torrefação, utilizando o preço do café torrado, preço do café solúvel, a demanda defasada em um período e variáveis dummy para captar o efeito do Plano Real e da participação da força de trabalho feminina na demanda interna de café. Foi observada elasticidade-preço igual a $-0,069$ com nivel de significância de 10\% (Quadro 7). 


\subsubsection{Literatura sobre equações de determinação de preços}

Há alguns trabalhos que avaliaram os fatores que determinam o preço do café. Entre esses trabalhos se destacam os de Hopp \& Foote (1955) e Mesquita (2000). O Quadro 8 ilustra resumidamente os principais pontos destes trabalhos.

Hopp \& Foote (1955) utilizaram um modelo linear de regressão para estimar os fatores que afetam o preço do café verde mundial para o período de 1882 a 1949. Nesse trabalho, não foram realizadas estimativas de elasticidades-preço e renda.

Mesquita (2000) estudou as variáveis que influenciam o preço pago ao produtor brasileiro de café. Para tanto, foi testada a influência das variáveis oferta e demanda mundiais de café na determinação do preço pago ao produtor brasileiro, ao mesmo tempo em que se avaliou a existência de causalidade na transmissão de preços entre a Coffee, Sugar and Cocoa Exchange, bolsa de mercadorias sediada em New York, e o mercado doméstico brasileiro. $\mathrm{O}$ autor utiliza um modelo de regressão linear em que o preço do café pago ao produtor brasileiro é a variável dependente e a demanda (consumo mundial) é uma das variáveis explicativas, juntamente com a produção mundial (oferta) e duas variáveis dummy referentes ao clima e mecanismos de regulação de preços. A binária referente a mecanismos de regulação de preços não foi significativa. A série utilizada foi de 28 anos.

\subsubsection{Avaliação global da literatura existente e a contribuição dessa dissertação}

É possível perceber que os trabalhos existentes sobre estimativas da demanda de café são numerosos e utilizam modelos diferentes e metodologias econométricas distintas, ainda que na maioria deles tenha sido utilizado o método dos mínimos quadrados ordinários, como nos trabalhos de Bacha (1968), Finageiv (1976) e Tamaki \& Larson (1982). O método de mínimos quadrados em dois estágios foi utilizado comparativamente com mínimos quadrados ordinários por Bacha (1968) e a metodologia de mínimos quadrados em três estágios foi explorada por Abaelu \& Manderscheid (1968), ao estimar a demanda norte-americana por cafés verdes por variedades 
(principais regiões produtoras). Praticamente, todos os estudos publicados fazem uso de dados do tipo séries temporais, sejam elas mensais, semestrais ou anuais.

Os diferentes modelos utilizados (considerando dados normais, logaritimizados ou preços relativos) demonstram as dificuldades de um único modelo gerar bons resultados econométricos. Isto sugere que para analisar períodos de tempo diferentes e mercados distintos, provavelmente, sejam necessários modelos diferentes.

As limitações observadas nos trabalhos são de natureza diversa, tendo sido poucas vezes notado coeficientes de determinação $\left(R^{2}\right)$ acima de $90 \%$. Os sinais esperados para os parâmetros estudados, que indicam o sentido da correlação, eventualmente divergiram do esperado, gerando uma inconsistência não explicada ou atribuída à qualidade insuficiente dos dados, como nos trabalhos de Daly (1958), Abaelu \& Manderscheid (1968) e Tamaki \& Larson (1982).

Com relação à faixa de tempo analisada, as estimativas dão conta de observações em mais de cem anos, de 1882 a 2000 . No entanto, quase nada se comenta sobre as mudanças que surgem ao longo do tempo nas elasticidades e sobre as diferenças dessas elasticidades entre os mercados. As séries utilizadas são em média de 15 a 20 anos, podendo ser encontrados trabalhos isolados como o de Hopp \& Foote (1955) que explora uma série de 68 anos e Paniago (1963) estudando séries temporais anuais de 44 anos. No entanto, nada é ressaltado sobre mudanças na estrutura da demanda de café ao longo do tempo.

As conclusões comuns à maioria dos estudos sugerem que a demanda externa e interna pelo café brasileiro é bastante inelástica ao preço, tendo sido encontrado diversos coeficientes de elasticidade. Com referência à elasticidade-renda da demanda, a discussão parece desconexa, pois há trabalhos que concluem que o café é um bem inferior (com Er negativa), como os trabalhos de Abaelu \& Manderscheid (1968) e Tamaki \& Larson (1982), e outros trabalhos que concluem que o café é um bem normal, mas com a demanda inelástica a variações da renda.

Portanto, mesmo após inúmeros trabalhos realizados com estimativas da demanda por café, parece não haver consenso nos resultados sobre elasticidades-preço e renda. 
Ainda não se sabe, de fato, como tem se comportado ao longo do tempo a demanda mundial pelo café brasileiro, analisando separadamente cada um dos principais mercados. É possível que as estruturas de mercado inerentes a cada país consumidor do café brasileiro afetem o formato da curva de demanda.

A contribuição dessa dissertação está na investigação especifica da demanda de café para cada mercado consumidor do café brasileiro (inclusive o mercado interno), levando em consideração as características de mercado e uma série temporal de 42 anos (1961 a 2002). Portanto, a presente dissertação considera um período de tempo e uma abrangência de países diferentes dos trabalhos ressaltados nos itens 1.3.1, 1.3.2 e 1.3.3.

\subsection{Organização do trabalho}

Este trabalho compõe-se de cinco capítulos, incluindo essa introdução. No capítulo 2 apresentam-se os modelos econométricos utilizados para as estimativas de demanda (externa e doméstica), os procedimentos econométricos e os dados utilizados. O capítulo 3 analisa a demanda por café brasileiro nos cinco países, considerados os mais importantes importadores do café brasileiro ao longo do tempo, bem como o mercado interno. No capítulo 4 apresentam-se os resultados das estimativas das equações de demanda e discutem-se os mesmos. O capítulo 5 traz as conclusões do trabalho e em anexo encontram-se as tabelas da revisão bibliográfica (anexo A), os dados utilizados nas estimativas (anexo B) e as tabelas que apresentam os resultados de todas as estimativas realizadas (anexo C). 


\section{MODELOS ECONOMÉTRICOS E PROCEDIMENTOS PARA ESTIMAR A EQUAÇÃO DE DEMANDA}

\subsection{Modelos econométricos}

A demanda pelo café brasileiro nos diferentes mercados pode ter comportamentos distintos. No entanto, algumas variáveis são essenciais para explicar essas demandas, tais como o preço do café, o preço da bebida substituta e a renda do país. Para captar a variável gosto por café, o consumo do período anterior pode ser considerado. A utilização da variável defasada capta a tendência da série, mudanças de hábitos e ainda contorna a questão da correlação entre os resíduos.

Se fosse considerado o preço como variável endógena, dever-se-ia estimar modelos de equações simultâneas considerando a demanda (o que se pretende estudar) e também a oferta. É fato ainda que alguns países abrangidos neste trabalho como a Alemanha, têm importância na oferta de cafés. No entanto, neste trabalho, adotou-se como pressuposto que o preço do café brasileiro no mercado externo é dado, a fim de se estimarem apenas equações de demanda e não equações simultâneas de demanda e oferta. Isto faz o trabalho ficar focado em seu objetivo.

De modo a avaliar como as variáveis independentes afetam o consumo de café, consideram-se modelos distintos para as demandas externa e doméstica pelo café brasileiro. A seguir, esses modelos são apresentados.

\subsubsection{Demanda externa}


Para se estimar a demanda externa, cada país consumidor será estudado separadamente, pois é possível que características individuais dos países consumidores, como o nível de renda e as preferências dos consumidores, influenciem individualmente a demanda por café brasileiro nesses mercados. É pertinente admitir que exista também maior ou menor competição entre cafés de diferentes origens em alguns mercados consumidores, assim como para as demais bebidas substitutas analisadas.

Os modelos sugeridos incluem as seguintes variáveis: preço do café brasileiro exportado para o mercado em questão, preço da bebida substituta, o índice da evolução do PIB do país e o valor defasado em um período da importação de café verde brasileiro pelo mercado analisado.

É fato que os bens que podem ser substitutos do café brasileiro (as bebidas estimulantes, como chás, refrigerantes ou outras bebidas) são variáveis importantes na função demanda, e podem ter relação com a variável dependente. Os bens que podem apresentar alguma substituição com o café brasileiro, explorados neste trabalho, são o café oriundo de outros países, o suco de laranja concentrado, o chá e outras bebidas não alcoólicas ${ }^{2}$. É importante destacar que o bem substituto a ser utilizado na estimativa de cada país pode variar. Portanto, é possível que os modelos sugeridos sofram algumas modificações nas variáveis explicativas de modo a melhor se ajustarem a cada mercado estudado. Foram considerados os preços de exportação, importação e a média aritmética dos preços de importação e exportação dos três tipos de bebidas alternativas acima mencionadas.

Para se estimar a demanda por café brasileiro em cada mercado analisado são propostos 22 modelos econométricos. Estes modelos estão distribuídos em dois grupos que envolvem estimativas com valores globais do consumo e renda e modelos estimados em termos per capita.

O Quadro 2 apresenta, a seguir, os modelos utilizados nas estimativas, representados pelas equações 1 a 22 .

\footnotetext{
${ }^{2}$ A FAO (Food and Agriculture Organization of the United Nations) - fonte de dados utilizada para os preços de outras bebidas - classifica como Non-Alcoholic Beverages, bebidas açucaradas, águas minerais com aditivos de sabor e outras bebidas não alcoólicas, como refrigerantes à base de limão, laranja e colas. Excluem-se desta categoria os sucos de frutas e vegetais.
} 


\begin{tabular}{|c|c|c|}
\hline & MODELOS COM CONSUMO E RENDA GLOBAIS & \\
\hline Modelo 1 & $\mathrm{Y}=\alpha+\beta_{1} \cdot \operatorname{Pr}+\beta_{2} \cdot \operatorname{Pio}+\beta_{3} \cdot \operatorname{Pib}+\beta_{4} \cdot \mathrm{Ydef}+\varepsilon$ & (1) \\
\hline Modelo 2 & $\mathrm{Y}=\alpha+\beta_{1} \cdot \operatorname{Pr}+\beta_{2} \cdot \operatorname{Peo}+\beta_{3} \cdot \operatorname{Pib}+\beta_{4} \cdot \mathrm{Ydef}+\varepsilon$ & (2) \\
\hline Modelo 3 & $\mathrm{Y}=\alpha+\beta_{1} \cdot \operatorname{Pr}+\beta_{2} \cdot \mathrm{Mo}+\beta_{3} \cdot \operatorname{Pib}+\beta_{4} \cdot \mathrm{Ydef}+\varepsilon$ & (3) \\
\hline Modelo 4 & $Y=\alpha+\beta_{1} \cdot \operatorname{Pr}+\beta_{2} \cdot \operatorname{Pic}+\beta_{3} \cdot \operatorname{Pib}+\beta_{4} \cdot Y \operatorname{def}+\varepsilon$ & (4) \\
\hline Modelo 5 & $Y=\alpha+\beta_{1} \cdot \operatorname{Pr}+\beta_{2} \cdot \operatorname{Pec}+\beta_{3} \cdot \operatorname{Pib}+\beta_{4} \cdot Y \operatorname{def}+\varepsilon$ & (5) \\
\hline Modelo 6 & $\mathrm{Y}=\alpha+\beta_{1} \cdot \operatorname{Pr}+\beta_{2} \cdot \mathrm{Mc}+\beta_{3} \cdot \operatorname{Pib}+\beta_{4} \cdot \mathrm{Ydef}+\varepsilon$ & (6) \\
\hline Modelo 7 & $Y=\alpha+\beta_{1} \cdot \operatorname{Pr}+\beta_{2} \cdot \operatorname{Pis}+\beta_{3} \cdot \operatorname{Pib}+\beta_{4} \cdot Y \operatorname{def}+\varepsilon$ & (7) \\
\hline Modelo 8 & $Y=\alpha+\beta_{1} \cdot \operatorname{Pr}+\beta_{2} \cdot \operatorname{Pes}+\beta_{3} \cdot \operatorname{Pib}+\beta_{4} \cdot Y \operatorname{def}+\varepsilon$ & (8) \\
\hline Modelo 9 & $Y=\alpha+\beta_{1} \cdot \operatorname{Pr}+\beta_{2} \cdot M s+\beta_{3} \cdot \operatorname{Pib}+\beta_{4} \cdot Y \operatorname{def}+\varepsilon$ & (9) \\
\hline Modelo 10 & $\mathrm{Y}=\alpha+\beta_{1} \cdot \operatorname{Pr}+\beta_{3} \cdot \operatorname{Pib}+\beta_{4} \cdot Y \operatorname{def}+\varepsilon$ & (10) \\
\hline \multirow[t]{2}{*}{ Modelo 11} & $\mathrm{Y}=\alpha+\beta_{1} \cdot \operatorname{Pr}+\beta_{2} \cdot \operatorname{Pcs}+\beta_{3} \cdot \operatorname{Pib}+\beta_{4} \cdot \mathrm{Ydef}+\varepsilon$ & (11) \\
\hline & MODELOS EM TERMOS PER CAPITA & \\
\hline Modelo 12 & $\mathrm{Ypc}=\alpha+\beta_{1} \cdot \operatorname{Pr}+\beta_{2} \cdot \operatorname{Pio}+\beta_{3} \cdot \operatorname{Pibpc}+\beta_{4} \cdot Y \operatorname{defpc}+\varepsilon$ & (12) \\
\hline Modelo 13 & $\mathrm{Ypc}=\alpha+\beta_{1} \cdot \operatorname{Pr}+\beta_{2} \cdot \operatorname{Peo}+\beta_{3} \cdot \operatorname{Pibpc}+\beta_{4} \cdot$ Ydefpc $+\varepsilon$ & (13) \\
\hline Modelo 14 & $\mathrm{Ypc}=\alpha+\beta_{1} \cdot \operatorname{Pr}+\beta_{2} \cdot \mathrm{Mo}+\beta_{3} \cdot \operatorname{Pibpc}+\beta_{4} \cdot \mathrm{Ydefpc}+\varepsilon$ & (14) \\
\hline Modelo 15 & Ypc $=\alpha+\beta_{1} \cdot \operatorname{Pr}+\beta_{2} \cdot \operatorname{Pic}+\beta_{3} \cdot \operatorname{Pibpc}+\beta_{4} \cdot$ Ydefpc $+\varepsilon$ & $(15)$ \\
\hline Modelo 16 & $\mathrm{Ypc}=\alpha+\beta_{1} \cdot \operatorname{Pr}+\beta_{2} \cdot \operatorname{Pec}+\beta_{3} \cdot \operatorname{Pibpc}+\beta_{4} \cdot \mathrm{Ydefpc}+\varepsilon$ & (16) \\
\hline Modelo 17 & $\mathrm{Ypc}=\alpha+\beta_{1} \cdot \operatorname{Pr}+\beta_{2} \cdot \mathrm{Mc}+\beta_{3} \cdot \operatorname{Pibpc}+\beta_{4} \cdot \mathrm{Ydefpc}+\varepsilon$ & (17) \\
\hline Modelo 18 & Ypc $=\alpha+\beta_{1} \cdot \operatorname{Pr}+\beta_{2} \cdot \operatorname{Pis}+\beta_{3} \cdot \operatorname{Pibpc}+\beta_{4} \cdot$ Ydefpc $+\varepsilon$ & (18) \\
\hline Modelo 19 & $\mathrm{Ypc}=\alpha+\beta_{1} \cdot \operatorname{Pr}+\beta_{2} \cdot \operatorname{Pes}+\beta_{3} \cdot \operatorname{Pibpc}+\beta_{4} \cdot \mathrm{Ydefpc}+\varepsilon$ & (19) \\
\hline Modelo 20 & $\mathrm{Ypc}=\alpha+\beta_{1} \cdot \operatorname{Pr}+\beta_{2} \cdot \mathrm{Ms}+\beta_{3} \cdot \mathrm{Pib}+\beta_{4} \cdot \mathrm{Ydefpc}+\varepsilon$ & $(20)$ \\
\hline Modelo 21 & $\mathrm{Ypc}=\alpha+\beta_{1} \cdot \operatorname{Pr}+\beta_{3} \cdot \operatorname{Pibpc}+\beta_{4} \cdot \mathrm{Ydefpc}+\varepsilon$ & $(21)$ \\
\hline Modelo 22 & $\mathrm{Ypc}=\alpha+\beta_{1} \cdot \operatorname{Pr}+\beta_{2} \cdot \operatorname{Pcs}+\beta_{3} \cdot \operatorname{Pibpc}+\beta_{4} \cdot Y \operatorname{defpc}+\varepsilon$ & $(22)$ \\
\hline
\end{tabular}

Quadro 2 - Modelos de regressão múltipla utilizados nas estimativas da demanda pelo café verde brasileiro nos mercados consumidores estudados 
Sendo:

$\mathrm{Y}=$ Importações de café verde do país i provenientes do Brasil';

Ypc $=$ Importações de café verde do país i provenientes do Brasil em termos per capita;

$\operatorname{Pr}=$ Preço do café verde brasileiro exportado para o país i;

$\mathrm{Pib}=$ Índice real do PIB;

Pibpc = Índice real do PIB em termos per capita;

Ydef = Variável $\mathrm{Y}$ defasada em 1 período;

Ydefpc $=$ Variável $Y$ defasada em 1 período em termos per capita;

Pio $=$ Preço de importação de outras bebidas não alcoólicas pelo país i;

Peo = Preço de exportação de outras bebidas não alcoólicas pelo país i;

Pic $=$ Preço de importação de chá pelo país i;

$P e c=$ Preço de exportação de chá pelo país i;

Pis = Preço de importação de suco de laranja pelo país i;

Pes = Preço de exportação de suco de laranja pelo país i;

Mo $=$ Média dos preços de importação e exportação de outras bebidas não alcoólicas pelo país i;

$\mathrm{Mc}=$ Média dos preços de importação e exportação de chá pelo país $\mathrm{i} ;$

Ms = Média dos preços de importação e exportação de suco de laranja pelo país i;

Pcs = Preço do café substituto ao café brasileiro no país $i$.

Esperar-se-á as seguintes relações entre as variáveis ${ }^{4}$ :

i) O preço do café brasileiro relacione-se negativamente com a demanda do mercado i;

ii) O preço da bebida substituta relacione-se positivamente com a demanda do mercado i;

\footnotetext{
${ }^{3}$ A variável Y representa a demanda de cada mercado estudado pelo café verde brasileiro.

${ }^{4}$ Não há relação esperada para a variável PIB, uma vez que o café será um bem normal ou de luxo quando se relacionar positivamente com a demanda do mercado i e será um bem inferior quando se relacionar negativamente com a demanda do mercado $i$.
} 
iii) A demanda defasada (Ydef) relacione-se positivamente com a demanda do mercado i;

O período considerado nas estimativas dos modelos 1 a 22 do Quadro 2 é de 1961 a 2002, utilizando dados do MDIC (Ministério do Desenvolvimento, Indústria e Comércio Exterior), FAO (Food and Agriculture Organization of the United Nations) e IPEA (Instituto de Pesquisa Econômica Aplicada). Maiores comentários sobre os dados estão no item 2.3.

\subsubsection{Demanda interna}

O período utilizado nas estimativas da demanda interna foi de 1961 a 2002, com dados anuais, totalizando 42 observações, considerando a perda da primeira observação (1960) por se tratarem de modelos auto-regressivos. Não foram utilizadas bebidas substitutas ao café brasileiro nas estimativas da demanda interna. O consumo interno de café no Brasil é composto por cafés essencialmente nacionais nos blends brasileiros. Portanto, a demanda interna de café a ser estimada é o consumo de café verde pela indústria de torrefação nacional.

Para se estimar a demanda interna pelo café verde brasileiro foram considerados, $a$ priori, dois modelos de regressão, apresentados no Quadro 3.

\begin{tabular}{|llr|}
\hline Modelo 1 & $\mathrm{Cpc}=\alpha+\beta_{1} \cdot \operatorname{Pr}+\beta_{2} \cdot \mathrm{Pibpc}+\beta_{3} \cdot$ Cpcdef $+\varepsilon$ & (23) \\
\hline Modelo 2 & $\operatorname{lnCpc}=\alpha+\beta_{1} \cdot \ln \mathrm{Pr}+\beta_{2} \cdot \operatorname{lnPibpc}+\beta_{3} \cdot \operatorname{lnCpcdef}+\varepsilon$ \\
\hline
\end{tabular}

Quadro 3 - Modelos de regressão múltipla utilizados nas estimativas da demanda interna pelo café verde brasileiro

Sendo:

$\mathrm{Cpc}=$ Consumo brasileiro de café verde em termos per capita;

$\mathrm{Pr}=$ Preço recebido pelo produtor paulista pela saca de café de $60 \mathrm{~kg}$ beneficiada;

Pibpc $=$ PIB brasileiro em termos per capita; 
Cpcdef $=$ Consumo brasileiro de café verde defasado em 1 período em termos per capita;

$\ln =$ logaritmo neperiano;

A partir dos modelos especificados, espera-se que:

i) A variável preço relacione-se negativamente com o consumo interno per capita;

ii) A demanda defasada, em termos per capita, (Cpcdef) relacione-se positivamente com o consumo interno;

A opção de estimar modelos de demanda interna de café com variáveis per capita, foi adotada com base na revisão bibliográfica do item 1.3.2, na qual todos os trabalhos revisados também consideraram variáveis per capita. Como alguns trabalhos revisados não obtiveram significância estatística pra a variável renda, poder-se-á estimar formas semi-logaritimicas se o mesmo ocorrer nas estimativas das equações (23) e (24).

\subsection{Procedimentos econométricos}

Os modelos propostos foram estimados com dados normais (não logaritimizados) e dados logaritimizados. Ao tomar os dados logaritimizados, têm-se as elasticidades diretamente dos coeficientes das variáveis independentes. Portanto, para a demanda externa, cada mercado estudado possui 44 modelos de regressão múltipla ${ }^{5}$ e para a demanda interna tem-se os dois modelos especificados no Quadro $3^{6}$.

Os modelos foram estimados através do método dos mínimos quadrados ordinários, utilizando-se o software SAS. Os resultados das estimativas estão tabulados em anexo. $\mathrm{O}$ capítulo 4 apresenta os modelos que se destacaram, onde se discute as estimativas.

\footnotetext{
${ }^{5}$ Além das 44 estimativas realizadas para cada mercado estrangeiro estudado (e apresentadas em anexo), é possível observar que há um modelo selecionado para cada país que foi re-estimado, considerando períodos diferentes. Estes procedimentos serão mais bem descritos no quinto item ainda neste capítulo.

${ }^{6}$ Além dos dois modelos especificados no Quadro 3, surgirão mais dois outros modelos incluindo variáveis binárias (ver Quadro 4 no capítulo 3).
} 
Os modelos 1 a 11 da demanda externa, representados pelas equações (1) a (11), que consideram consumo e renda totais, foram especificados desta maneira na tentativa de se obter melhores ajustes entre as variáveis.

A variável preço do café substituto (Pcs), medido em dólares por saca (US\$/sc), é obtida a partir da equação 25 , apresentada a seguir:

$$
P c s=\frac{V m-V x}{M-X}, \text { sendo }
$$

$\mathrm{Vm}=$ Valor das importações globais de café do país i (US\$);

$\mathrm{Vx}=$ Valor das exportações brasileiras de café para o país i (US\$) ${ }^{7}$;

$\mathrm{M}=$ Quantidade total importada de café pelo país i (sacas);

$\mathrm{X}=$ Quantidade de café brasileiro importado pelo país i (sacas) $^{8}$.

Segundo GUJARATI (2000), com relação aos procedimentos adotados para testar a presença de autocorrelação nos modelos estimados, deve-se considerar que:

$1^{\text {o }}$ ) A estatística de Durbin-Watson não é indicada para detectar correlação serial (de primeira ordem) em modelos autoregressivos, porque o valor calculado de $d$ (o teste de Durbin-Watson) em tais modelos tende geralmente para 2, que é o valor de d esperado em uma seqüência verdadeira aleatória. Portanto, há um viés embutido contra a descoberta da correlação serial (de primeira ordem) ao se usar a estatística DurbinWatson.

$\left.2^{\underline{0}}\right) \mathrm{O}$ teste $\mathrm{h}$, proposto por Durbin, é adequado para grandes amostras de correlação serial de primeira ordem em modelos auto-regressivos. A estatística h pode ser calculada conforme a equação (26), apresentada a seguir:

$$
h=\hat{\rho} \sqrt{\frac{n}{1-n\left[\operatorname{var}\left(\hat{\alpha}_{2}\right)\right]}}
$$

Sendo:

$\mathrm{n}=$ número de observações;

$\operatorname{var}\left(\hat{\alpha}_{2}\right)=$ variância do coeficiente de $\mathrm{Y}_{\mathrm{t}-1}$ defasado;

$\hat{\rho}=$ estimativa da correlação serial de primeira ordem $\rho$.

\footnotetext{
${ }^{7}$ É o mesmo que o valor das importações de café brasileiro pelo mercado em questão.

${ }^{8}$ É o mesmo que quantidades importadas de café brasileiro pelo mercado em questão.
} 
Na prática, não é necessário calcular $\hat{\rho}$, pois ela pode ser aproximada por meio do d estimado conforme a equação (27) a seguir:

$$
\hat{\rho} \cong 1-\frac{1}{2} d
$$

Portanto, sendo d a estatística Durbin-Watson usual, a equação (26) pode ser reescrita conforme apresentado pela equação (28):

$$
h=\left(1-\frac{1}{2} d\right) \sqrt{\frac{n}{1-n\left[\operatorname{var}\left(\hat{\alpha}_{2}\right)\right]}}
$$

$3^{0}$ ) A estatística h se distribui normalmente com média zero e variância um. E a partir da distribuição normal, tem-se a equação (29):

$\operatorname{Pr}(-1,96 \leq \mathrm{h} \leq 1,96)=0,95$

Portanto, a probabilidade de $\mathrm{h}$ se encontrar entre $-1,96$ e 1,96 é de aproximadamente $95 \%$. Assim sendo, tem-se que:

i) Se $\mathrm{h}>1,96$, rejeita-se a hipótese nula de que não há autocorrelação positiva de primeira ordem;

ii) Se $\mathrm{h}<-1,96$, rejeita-se a hipótese nula de que não há autocorrelação negativa de primeira ordem;

iii) Se h encontrar-se entre -1,96 e 1,96, não rejeita-se a hipótese nula de que não há autocorrelação de primeira ordem (positiva ou negativa);

$\left.4^{\mathrm{o}}\right)$ A variância $\left[\operatorname{var}\left(\hat{\alpha}_{2}\right)\right]$ da variável dependente defasada $\left(\mathrm{Y}_{\mathrm{t}-1}\right)$ é obtida a partir do quadrado do erro-padrão $(\sigma)$ estimado desta variável.

Para se obter as elasticidades preço e renda da demanda, foram adotados os seguintes procedimentos:

i) Em modelos estimados com dados tomados em logaritmo, as elasticidades (renda e preço da demanda) são iguais aos coeficientes estimados;

ii) Para os modelos estimados com dados não logaritmizados, faz-se necessário calcular as elasticidades a partir da equação (30), apresentada a seguir, para a elasticidade preço da demanda.

$$
\varepsilon p=\operatorname{coef} * \frac{\overline{\operatorname{Pr}}}{\overline{\bar{Y}}}
$$


Sendo;

$\varepsilon p$ = Elasticidade preço da demanda;

coef. $=$ Coeficiente estimado associado à variável preço do café brasileiro no mercado i;

$\overline{\operatorname{Pr}}=$ Média da variável independente preço do café brasileiro no mercado i;

$\bar{Y}=$ Média da variável dependente importação de café verde brasileiro pelo mercado i.

Para se estimar a elasticidade renda nos modelos não logaritimizados, adota-se a mesma sistemática de cálculo. A equação (31) apresenta a equação utilizada para o cálculo da elasticidade renda.

$$
\varepsilon r=\operatorname{coef} * \frac{\overline{P I B}}{\bar{Y}}
$$

Sendo;

$\varepsilon r=$ Elasticidade renda;

$\overline{P I B}=$ Média da variável independente PIB do mercado i;

Seguindo-se a mesma lógica, usam-se ainda as médias das variáveis importações per capita de café verde brasileiro pelo mercado i $(\bar{Y} p c)$ e o PIB per capita $(\overline{P i b p c})$ para se obterem as elasticidades preço e renda nos modelos 12 a 22 , representados pelas equações (12) a (22), estimados em termos per capita.

$5^{0}$ ) As regressões são estimadas para três períodos. Inicialmente, as regressões do Quadro 2 são estimadas para o periodo de 1961 a 2002, selecionando a melhor. Esta última, por sua vez, é re-estimada para os períodos de 1970 a 2002 e de 1980 a 2002. Procurar-se-á, com isto, verificar mudanças nas elasticidades-preço e renda da demanda que possam estar ocorrendo ao longo do tempo, justificando assim a divisão da série nestes períodos. A escolha dos períodos a serem re-estimados não está associada a nenhum evento. A intenção foi captar mudanças nas elasticidades ao longo do tempo. No caso das equações de demanda doméstica de café, serão usadas variáveis binárias para captar mudanças de tendências, tal como será explicado no item 3.7 do próximo capítulo. 


\subsection{Os dados}

Para analisar a demanda externa são utilizados dados de três fontes de dados secundários:

i) $\mathrm{MDIC}^{9}$ (antiga CACEX e sistema Alice), que fornece dados de volume e valor da exportação brasileira de café (total e por países);

ii) FAO (Food and Agriculture Organization of the United Nations), que fornece dados de volume e valor ${ }^{10}$ das importações totais de café dos principais países consumidores de café; o volume e valor das importações totais das bebidas substitutas ao café por países; e a população por países;

iii) IPEA (Instituto de Pesquisa Econômica Aplicada), que fornece o índice do PIB para os países analisados (dados secundários - fonte: FMI) e índice de preços no atacado (IPA - base $1995=100$ ), nos EUA, utilizados para deflacionar os preços de exportação de café verde brasileiro ${ }^{11}$.

As tabelas 10 a 14, em anexo, apresentam os dados utilizados nas regressões da demanda de café brasileiro pelos EUA, Alemanha, Itália, França e Japão.

Para analisar a demanda interna, quatro fontes de dados secundários são utilizadas:

i) IBC (Instituto Brasileiro do Café, extinto em 1990), do qual se obtém dados de consumo interno no período de 1960 a 1989, publicados no Anuário Estatístico do Café;

ii) ABIC (Associação Brasileira da Indústria de Café), que fornece dados de consumo interno no período de 1990 a 2002;

iii) IPEA (Instituto de Pesquisas Econômicas Aplicadas), que fornece dados de população e PIB brasileiro;

\footnotetext{
${ }^{9}$ Foi utilizada a base de dados ALICE do MDIC (Ministério do Desenvolvimento, Indústria e Comércio Exterior) - Antiga CACEX, para coleta de dados secundários de exportações brasileiras de café a partir de 1989. Os dados anteriores a este período foram obtidos diretamente nos anuários de comércio exterior da CACEX por ainda não estarem disponíveis on line no sistema atual.

${ }^{10}$ A partir de onde se obtém os preços.

" As séries de preço (obtidas a partir de volume e valor) das exportações brasileiras de café verde para os mercados estudados estão dolarizadas no sistema ALICE e foram deflacionadas pelo IPA norte-americano, com base em $1995(1995=100)$, corrigindo-se o efeito inflacionário.
} 
iv) IEA (Instituto de Economia Agrícola), que fornece os preços da saca de café recebida pelo produtor no Estado de São Paulo.

O IGP-DI (Índice Geral de Preços - Disponibilidade Interna) foi o índice utilizado para deflacionar as séries de preço (agosto de $1994=100$ ) e PIB brasileiro (dezembro de $2003=100)$.

A tabela 15, em anexo, apresenta os dados utilizados nas regressões da demanda doméstica pelo café brasileiro. 


\section{ANÁliSE DOS PRINCIPAIS MERCADOS CONSUMIDORES DE CAFÉ DO BRASIL}

Este capítulo analisa, inicialmente, a evolução do volume das exportações brasileiras e dos preços do produto exportado, destacando os ciclos e tendências existentes. Em seguida, avaliam-se alguns aspectos do consumo de café em países selecionados, dando-se ênfase ao montante de café exportado pelo Brasil a esses países, o market share do Brasil nas importações totais de café, a disputa que o café tem com outras bebidas e a tendência recente do consumo de café nesses países. Selecionaram-se para análise os EUA, Alemanha, Japão, Itália, França e o próprio Brasil.

A intenção deste capítulo é ressaltar que as exportações brasileiras apresentam dinamismo diferente segundo o país importador e essas diferenças podem implicar em estimativas diferentes das equações de demanda de café.

\subsection{Evolução das exportações brasileiras de café}

Do total de café verde exportado pelo Brasil, aproximadamente $75 \%$ é representado por grãos arábica e $15 \%$ trata-se de café robusta (conillon), que é cultivado em regiões de menor altitude e mais quentes. Os demais $10 \%$ referem-se aos cafés solúvel e torrado ${ }^{12}$.

A figura 1 apresenta a evolução das exportações brasileiras de café verde de 1961 a 2002, em volume comercializado (sacas de $60 \mathrm{~kg}$ ) e preço FOB por saca (US\$), deflacionado pelo índice de preços no atacado dos Estados Unidos. Há significativas oscilações no volume e preço do café brasileiro exportado anualmente. No entanto,

${ }^{12}$ CONSELHO DOS EXPORTADORES DE CAFÉ DO BRASIL (CECAFÉ). Dados estatísticos. http://www.cecafe.com.br (05 jun. 2004) 
podem-se constatar alguns ciclos, correspondentes aos períodos 1961 a 1969, 1970 a 1992 e 1993 a 2002 (períodos representados pelas barras verticais pontilhadas). No primeiro ciclo (1961 a 1969) observa-se que as quantidades exportadas diminuíram e os preços aumentaram de 1961 a 1965 e o inverso ocorreu de 1966 a 1969 (representados pelas barras verticais tracejadas). No segundo ciclo (1970 a 1992) as quantidades exportadas diminuíram e os preços aumentaram de 1970 a 1977, tendo o inverso ocorrido entre 1978 a 1992. No terceiro ciclo (1993 a 2002), as quantidades exportadas diminuíram e os preços aumentaram de 1993 a 1995 e o inverso ocorreu de 1996 a 2002.

Esses ciclos têm suas durações e intensidades afetadas por fatores internos e externos à economia brasileira. A ocorrência de geadas e outras adversidades climáticas podem intensificar em alguns anos aumentos de preços em fases de ciclo de alta de preços (como em 1977 e 1994) ou causar uma recuperação não sustentada de preços em uma fase de ciclo de baixa de preços (como em 1986).

Comparando os três ciclos completos de preço e exportação entre si, observa-se que de 1961 a 1977 a tendência do volume exportado de café pelo Brasil foi de diminuir e os preços aumentarem. O inverso (aumento da quantidade exportada e queda de preços) é a tendência do período de 1978 a 2001.

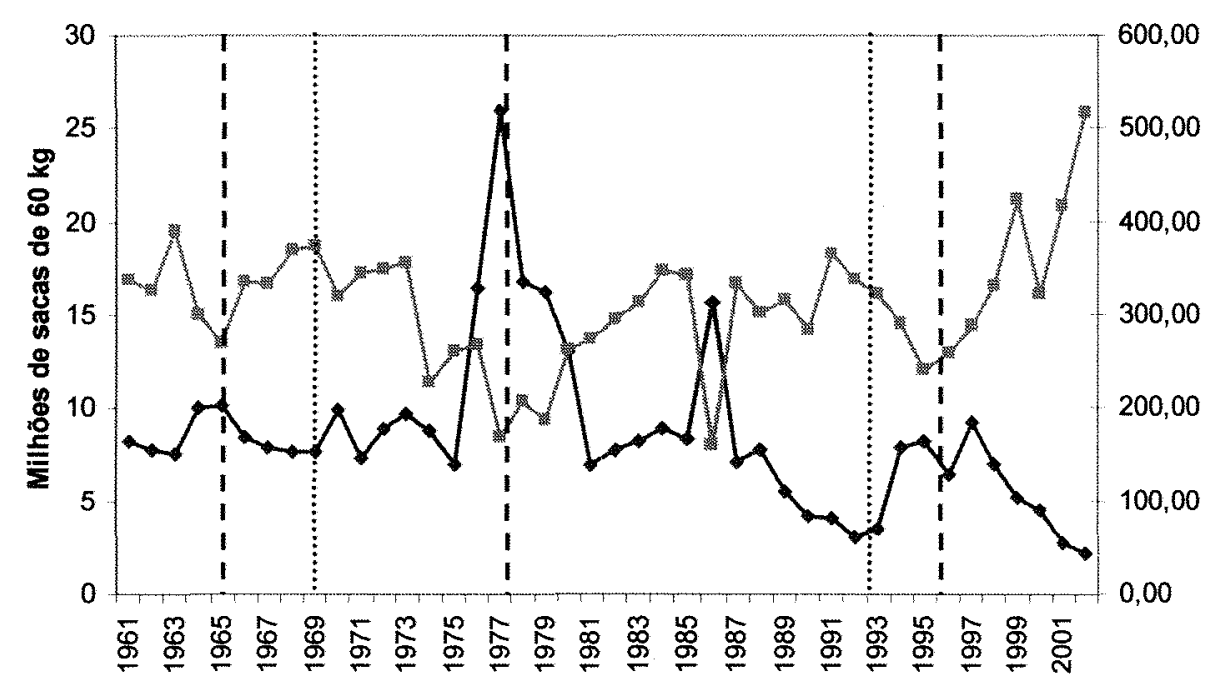

US\$/sc deflac. (IPA - EUA) sacas de $60 \mathrm{~kg}$

Figura 1 - Exportações brasileiras de café verde

Fonte: IBC (1989); Brasil (2003) 
Ainda que o aumento na demanda mundial por café possa ser notado, ele tem sido considerado ínfimo, dado o potencial de expansão do consumo da bebida. Tem-se atribuído este efeito às mudanças nas preferências dos consumidores, associadas aos hábitos de consumo e à dificuldade dos países produtores em sustentar níveis de oferta do produto diante dos preços baixos recebidos e eventuais intempéries climáticas ${ }^{13}$, ou problemas de estabilidade política interna.

As exportações brasileiras de café têm aumentado menos que a demanda mundial desse produto. Até meados da década de 90 , a oferta brasileira no mercado internacional oscilou pouco; ao redor de 15 milhões de sacas por ano, como pode ser observado na figura 2. Deve-se destacar que o aumento na demanda mundial, não acompanhado pelas exportações brasileiras, tem sido preenchido por cafés de outros países produtores, como o Vietnã, que vêm crescendo sua participação nas exportações mundiais.

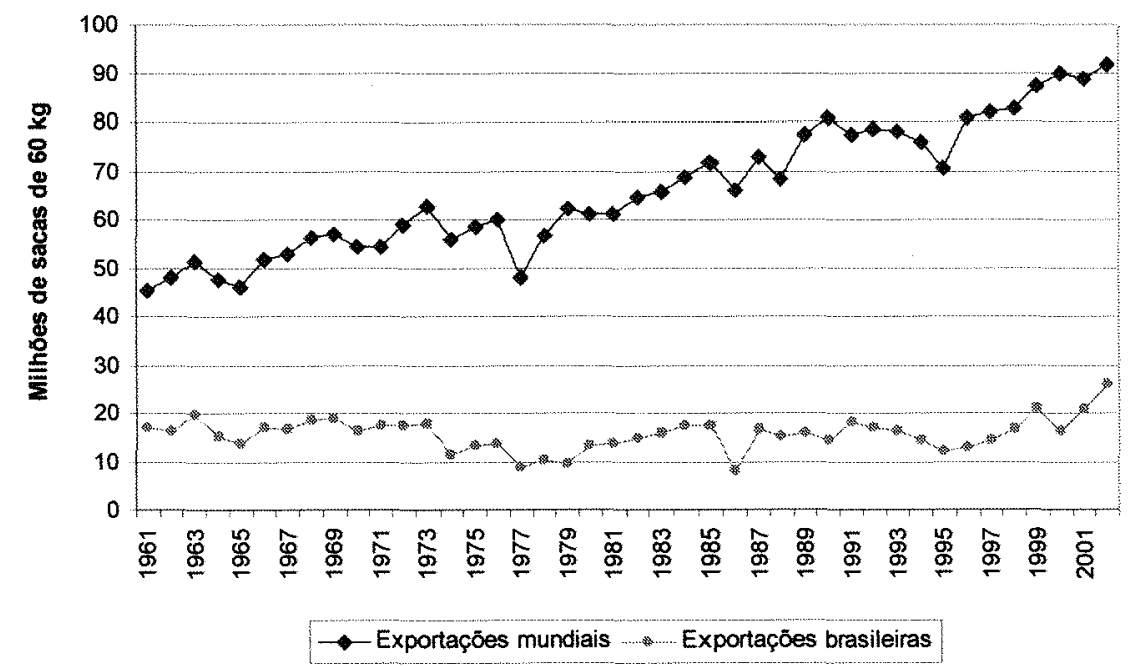

Figura 2 - Exportações mundiais e brasileiras de café verde (em milhões de sacas de 60 $\mathrm{kg})$

Fonte: FAO (2003)

A participação brasileira no mercado internacional de café verde, como conseqüência do acima exposto, tem sido decrescente ao longo do tempo. Na figura 3, é

\footnotetext{
${ }^{13}$ Deve-se lembrar que o Brasil é o único país grande produtor a sofrer problemas com geadas. No entanto, os países africanos e, no passado, os asiáticos e centro-americanos tiveram instabilidades políticas intenas (como guerras civis) que afetaram a produção de café.
} 
possível perceber que o Brasil respondia por aproximadamente $37 \%$ do total mundial exportado de café em 1961, ao passo que em 2002, este percentual não chega a $30 \%$.

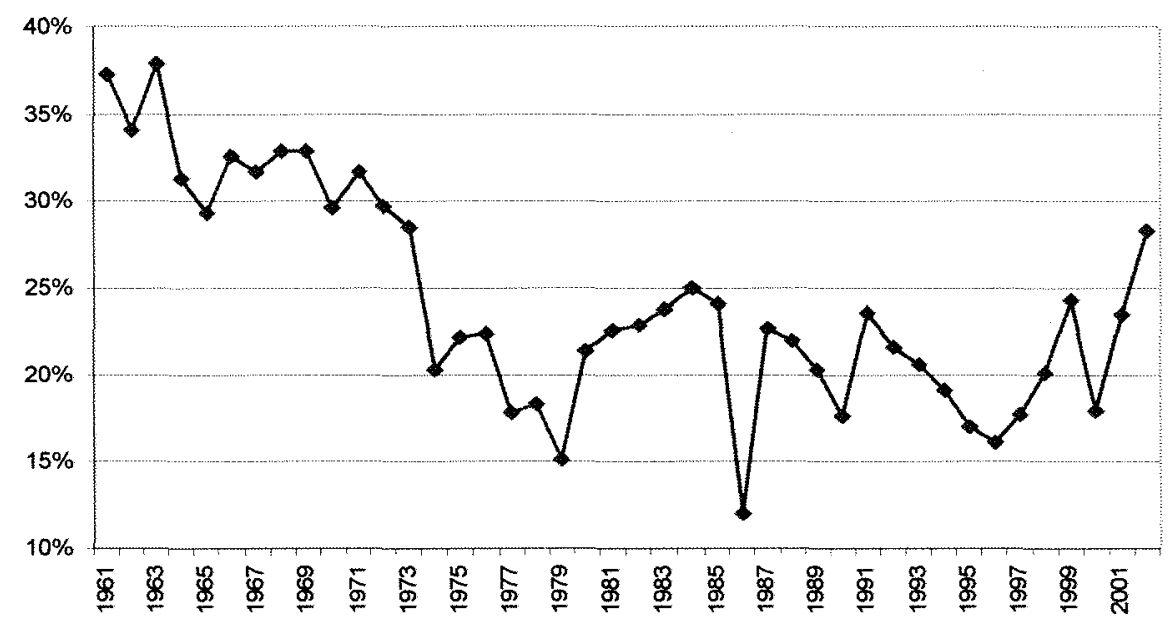

Figura 3 - Participação das exportações brasileiras nas exportações totais de café verde Fonte: FAO (2003)

Tem-se observado, nos últimos anos, alguns países industrializados (como Itália, Alemanha e EUA, tradicionais importadores de cafés verdes) aumentando suas receitas com a transformação da matéria-prima em cafés torrado e moído com maior valor agregado. Estes países têm sido eficientes em aproveitar nichos de cafés especiais industrializados associados a programas de marketing sobre as marcas importadas. Tem sido observada, ainda, a reexportação de cafés verdes com aumentos nas margens de lucro nas operações de corretagem destes países.

A tabela 1 apresenta a participação dos principais mercados consumidores do café brasileiro em percentual. A tendência da participação de cada mercado consumidor ao longo do tempo será discutida separadamente para cada mercado analisado (itens 3.2 a 3.8). No entanto, o que se deseja ressaltar na tabela 1 é que, ao longo do tempo, as participações mudaram e outros mercados (não apresentados na tabela 1), que foram importantes em determinado momento, não foram representativos quando considerada toda a série estudada. Deve-se salientar, ainda, que hoje novos mercados têm-se 
destacado como potenciais consumidores do café brasileiro (caso da China, por exemplo). No entanto, eles não foram expressivos ao longo do tempo.

Tabela 1. Participação dos principais mercados consumidores nas exportações brasileiras de café verde (em percentual)

\begin{tabular}{lcccccccc}
\hline & 1961 & 1970 & 1975 & 1980 & 1985 & 1990 & 1995 & 2001 \\
\hline EUA & $50,6 \%$ & $30,9 \%$ & $21,4 \%$ & $25,7 \%$ & $33,7 \%$ & $28,8 \%$ & $14,5 \%$ & $13,4 \%$ \\
Alemanha & $4,3 \%$ & $6,4 \%$ & $6,2 \%$ & $10,5 \%$ & $11,4 \%$ & $9,2 \%$ & $5,6 \%$ & $19,4 \%$ \\
Itália & $5,1 \%$ & $14,0 \%$ & $9,0 \%$ & $11,4 \%$ & $10,5 \%$ & $8,2 \%$ & $10,4 \%$ & $9,7 \%$ \\
França & $3,1 \%$ & $4,4 \%$ & $5,0 \%$ & $6,1 \%$ & $8,5 \%$ & $4,7 \%$ & $2,8 \%$ & $4,4 \%$ \\
Japão & $0,2 \%$ & $0,7 \%$ & $1,9 \%$ & $5,1 \%$ & $9,4 \%$ & $6,3 \%$ & $7,3 \%$ & $7,5 \%$ \\
\hline
\end{tabular}

Fonte: Brasil (2003)

\subsection{EUA}

Os EUA têm sido, de modo geral, o maior importador do café verde brasileiro, nas últimas quatro décadas. Contudo, este mercado tem sido, ao longo do tempo, cada vez menor, como pode ser observado na figura 4. 


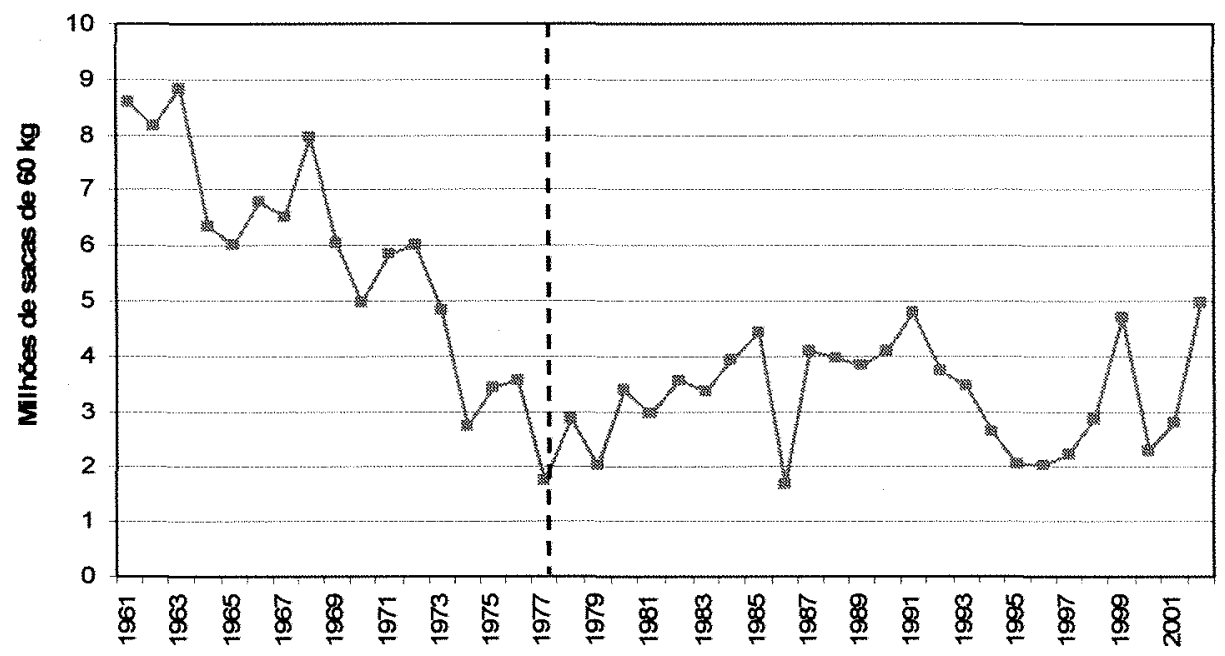

Figura 4 - Exportações brasileiras de café verde para os EUA Fonte: FAO (2003)

As exportações brasileiras de café verde para o mercado norte-americano diminuíram de 1961 a 1977, flutuando a partir de 1978 ao redor de 3 milhões de sacas por ano. Observa-se que a redução da quantidade exportada pelo Brasil nos anos 1961 a 1977 coincide com a fase de alta de preços evidenciada na figura 1. É interessante ressaltar que a redução de preços vigente a partir de 1978 não permitiu a recuperação do volume exportado para os EUA.

A figura 5 apresenta o market share do café brasileiro nos EUA, Alemanha, Itália, França e Japão. 

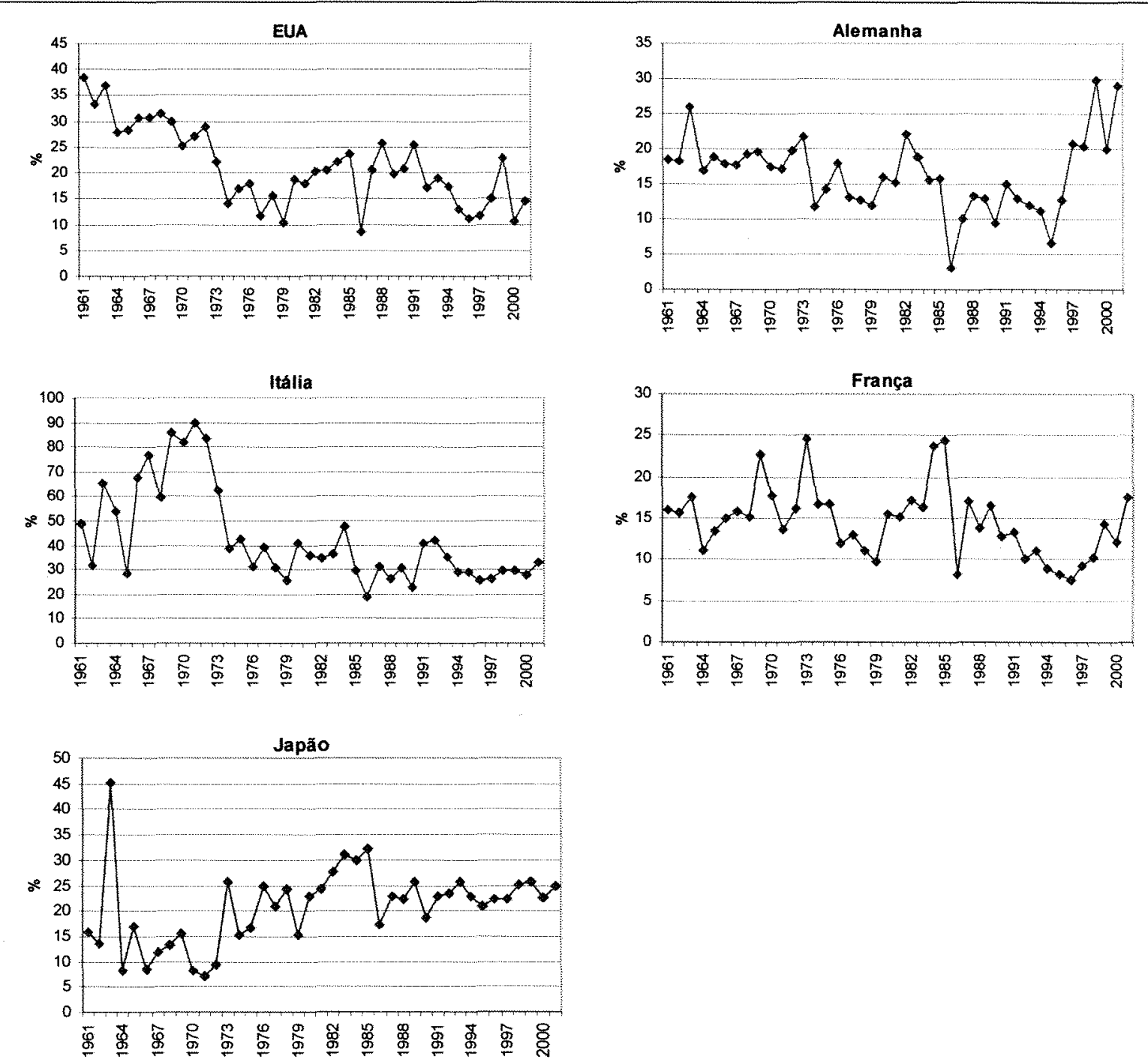

Figura 5 - Participação das exportações brasileiras nas importações totais de café verde (market share) em cinco mercados consumidores, em percentual Fonte: FAO (2003); Brasil (2003)

É possivel observar que a tendência do market share do café brasileiro nos EUA é decrescente ao longo do tempo. A participação do café brasileiro nas importações totais de café nos EUA, que era de aproximadamente $40 \%$ no início dos anos 60 , cai 
acentuadamente até 1979 , chegando a 10\%. Após este período, ocorreu uma flutuação na participação em torno de 10 e $25 \%$ até 2001 .

Enquanto houve redução na importação norte-americana de café verde brasileiro, os demais países produtores têm contribuído para a formação dos blends americanos como o México, Colômbia e Guatemala, aumentando suas receitas cambiais e tornando-se importantes exportadores da commodity.

Segundo Saes \& Farina (1999), a perda de participação brasileira no mercado norteamericano de café se deve principalmente a quatro fatores:

i) A competição com outras bebidas como refrigerantes, que sofreram enormes investimentos em marketing;

ii) Aumento do consumo de cafés especiais produzidos por países concorrentes, em detrimento dos cafés tradicionais ${ }^{14}$;

iii) Incerteza do fluxo de oferta decorrente de problemas climáticos ${ }^{15} \mathrm{e}$;

iv) Substituição de cafés escassos por cafés mais baratos, como robustas do Vietnã, Costa do Marfim e Indonésia.

Com relação à estrutura de mercado de café norte-americana, deve-se destacar a grande concentração da indústria torrefadora. As importações de café são absorvidas por poucas empresas ou grupos alimentícios, como a Nestlé, General Foods (Phillip Moris) e Folgers (Procter \& Gamble). Essas empresas têm grande poder de mercado.

Ainda segundo Saes \& Farina (1999), é possível encontrar inúmeras marcas de cafés torrados no varejo norte-americano, porém, processados por poucas indústrias torrefadoras. Devido ao alto poder de barganha dessas empresas, é intuitivo que elas exerçam alguma influência na formação de preços, por disporem de estratégias de importação de café verde de modo a aproveitar, na forma de estoques, os períodos de baixos preços do café no mercado internacional.

\footnotetext{
${ }^{14} \mathrm{O}$ aumento na demanda de cafés especiais nos EUA é favorável para o Brasil, devido a suas condições edáfo-climáticas de produção de grãos especiais. No entanto, essa vantagem comparativa não tem sido explorada, pois o Brasil ainda produz um volume pequeno de grãos selecionados e o que produz, não é acompanhado de ações estratégicas de marketing que dê destaque ao produto nacional. Ao se tratar de cafés especiais, países como a Colômbia ou Jamaica tem tido destaque como produtores, enquanto a produção brasileira está associada à quantidade e não à qualidade.

${ }^{15}$ Isto faz com que o café brasileiro não seja utilizado normalmente como base dos blends nas torrefadoras.
} 
Nos EUA, o café é consumido como bebida quente ou, alternativamente gelado, como sorvetes e mousses. O café solúvel conta com público fiel pela praticidade no preparo, tendo importância notável na preferência dos consumidores. O leque de novas bebidas que tem surgido à base de café, incluindo as geladas, têm sido crescente e tem ganhado a preferência dos jovens americanos. Isto, no entanto, não tem sido capaz de elevar o consumo per capita de café.

A tabela 2 apresenta o consumo global de café nos principais mercados consumidores a partir de 1990 .

Tabela 2. Consumo de café nos principais mercados consumidores - ano safra (em milhões de sacas de $60 \mathrm{~kg}$ )

\begin{tabular}{lcccccc}
\hline & EUA & Alemanha & Itália & França & Japão & Brasil \\
\hline $1990 / 91$ & 18,9 & 10,6 & 4,5 & 5,7 & 5,4 & 8,2 \\
$1991 / 92$ & 18,7 & 10,2 & 4,4 & 5,6 & 5,8 & 8,5 \\
$1992 / 93$ & 18,5 & 10,7 & 4,8 & 5,4 & 5,6 & 8,9 \\
$1993 / 94$ & 18,2 & 10,1 & 4,8 & 5,4 & 6,1 & 9,1 \\
$1994 / 95$ & 17,0 & 10,6 & 4,7 & 5,1 & 6,0 & 9,3 \\
$1995 / 96$ & 18,1 & 9,8 & 4,7 & 5,5 & 6,0 & 10,1 \\
$1996 / 97$ & 17,8 & 9,8 & 4,9 & 5,6 & 6,4 & 11,0 \\
$1997 / 98$ & 18,2 & 9,0 & 4,8 & 5,3 & 5,9 & 11,5 \\
$1998 / 99$ & 19,1 & 10,5 & 5,0 & 5,3 & 6,3 & 12,2 \\
$1999 / 00$ & 18,7 & 9,4 & 5,1 & 5,4 & 6,7 & 12,7 \\
$2000 / 01$ & 19,4 & 9,7 & 5,2 & 5,4 & 6,8 & 13,2 \\
$2001 / 02$ & 18,7 & 9,1 & 5,2 & 5,4 & 7,0 & 13,6 \\
\hline
\end{tabular}

Fonte: United States Department of Agriculture (USDA) (2003); ABIC (2003)

É possível perceber que houve uma ligeira queda no consumo interno norteamericano na primeira metade da década de 90 , passando de 18,9 milhões de sacas de 60 kg em 1990/91, para 17 milhões até o ano safra 1994/95. Esta queda no consumo dos EUA coincide com a tendência ascendente de preços do mesmo período, como pode ser 
observado na figura 1. A partir de 1994/95, o consumo tem crescido a taxas pequenas, com a redução dos preços na segunda metade da década de 90 .

Observando o consumo de café nos EUA em termos per capita, apresentado na tabela 3 (em $\mathrm{kg}$ de café verde/habitante/ano), é possível notar a estagnação do consumo em torno de $4 \mathrm{~kg} /$ habitante/ano desde 1994. Esta constatação pode estar associada à competição com outras bebidas como chás e refrigerantes, disputando a preferência do consumidor nos EUA.

Tabela 3. Consumo per capita de café nos principais mercados consumidores - ano safra (em kg de café verde/habitante/ano)

\begin{tabular}{lcccccc}
\hline & EUA & Alemanha & Itália & França & Japão & Brasil \\
\hline $1990 / 91$ & 4,5 & 8,0 & 4,8 & 6,0 & 2,6 & 3,4 \\
$1991 / 92$ & 4,4 & 7,7 & 4,6 & 5,9 & 2,8 & 3,5 \\
$1992 / 93$ & 4,3 & 8,0 & 5,1 & 5,7 & 2,7 & 3,6 \\
$1993 / 94$ & 4,2 & 7,5 & 5,0 & 5,6 & 2,9 & 3,6 \\
$1994 / 95$ & 3,8 & 7,8 & 4,9 & 5,3 & 2,9 & 3,7 \\
$1995 / 96$ & 4,0 & 7,2 & 4,9 & 5,7 & 2,9 & 3,9 \\
$1996 / 97$ & 3,9 & 7,2 & 5,1 & 5,8 & 3,0 & 4,2 \\
$1997 / 98$ & 4,0 & 6,6 & 5,1 & 5,5 & 2,8 & 4,3 \\
$1998 / 99$ & 4,1 & 7,7 & 5,2 & 5,5 & 3,0 & 4,5 \\
$1999 / 00$ & 4,0 & 6,9 & 5,3 & 5,5 & 3,2 & 4,7 \\
$2000 / 01$ & 4,1 & 7,1 & 5,4 & 5,4 & 3,2 & 4,8 \\
$2001 / 02$ & 3,9 & 6,7 & 5,4 & 5,4 & 3,3 & 4,9 \\
\hline
\end{tabular}

Fonte: elaborado a partir de USDA (2003); FAO (2003) e ABIC (2003) 


\subsection{Alemanha}

Observando a figura 6, é possível perceber que, diferentemente dos EUA, a Alemanha vem ampliando suas importações de café brasileiro, suplantando em 1997, pela primeira vez, os EUA como maior importador de café brasileiro ${ }^{16}$. A partir de então, a Alemanha alterna com os EUA a posição de maior consumidor de café brasileiro. A Alemanha tem comprado café do Brasil e demais países produtores de cafés suaves, agregando valor (torrando e moendo), para reexportar café para a Europa, Ásia, África e América do Norte.

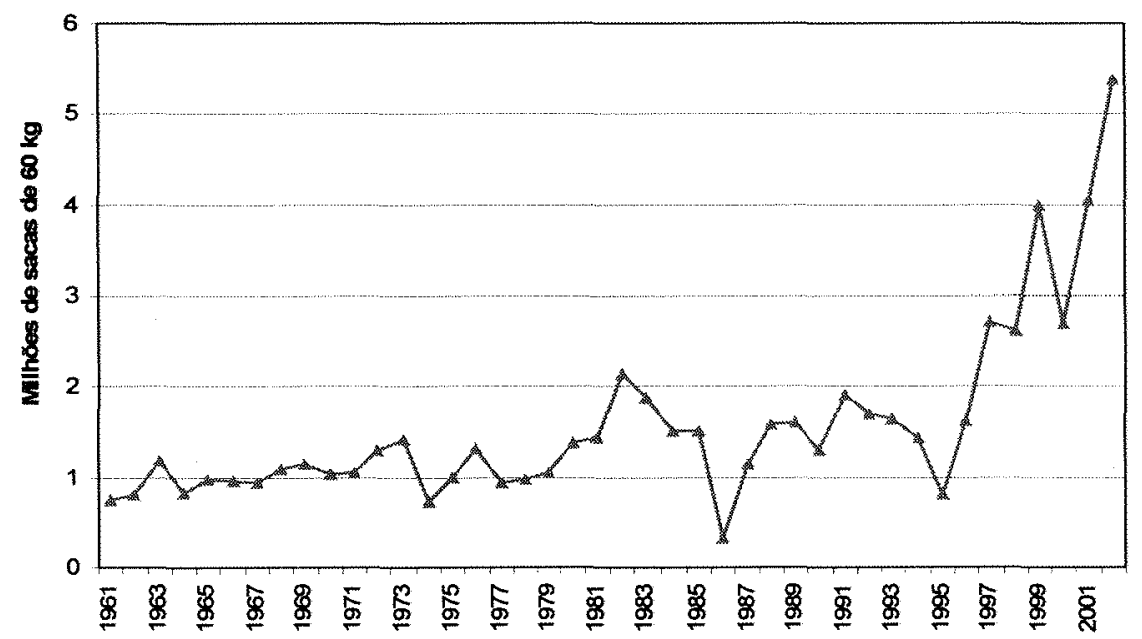

Figura 6 - Exportações brasileiras de café verde para a Alemanha Fonte: FAO (2003)

Saes \& Farina (1999) destacam que o incremento das exportações brasileiras de café para a Alemanha (tradicional consumidora de cafés de origens suaves) está associado à manutenção da qualidade do café importado. Este país tem ainda adotado uma estratégia para substituir a escassez de café arábica: a tecnologia de vaporização do café robusta; o mesmo equipamento utilizado na descafeinação, que permite reduzir a aspereza do paladar da matéria-prima e neutralizar o impacto nos blends.

${ }^{16}$ No ano de 1997, a Alemanha importou 2,7 milhões de sacas de café verde do Brasil, contra 2,2 milhões de sacas de café exportadas do Brasil para o mercado norte-americano. 
O market share do café brasileiro nas importações alemãs apresentou tendência decrescente entre 1961 e 1986, passando de quase $20 \%$ do total importado para $3 \%$ em 1986 (figura 5). É possível perceber, ainda, que após 1986 houve tendência de crescimento da participação brasileira nas importações totais de café realizadas pela Alemanha, chegando próximo a 30\%, em 2001.

O consumo total de café na Alemanha tem diminuído, passando de 10,6 milhões de sacas em 1990/91 para 9,1 milhões de sacas em 2001/02 (tabela 2). O consumo per capita alemão reduziu de $8 \mathrm{~kg} / \mathrm{habitante} /$ ano em 1990/91 para $6,7 \mathrm{~kg} /$ habitante/ano em 2001/02 (tabela 3). Apesar desta tendência decrescente, a Alemanha foi em 2001/02 o maior país consumidor per capita de café, entre os mercados estudados, como pode ser observado na tabela 3 .

\subsection{Itália}

As exportações brasileiras de café verde para a Itália podem ser visualizadas na figura 7 a seguir. Essas exportações são afetadas pelo preço do café brasileiro. A elevação desses preços no período de 1971 a 1977 (figura 1) foi acompanhada da redução das importações italianas de café brasileiro (figura 7). O salto de preços de 1986 também foi marcado pela redução das importações italianas de café brasileiro neste ano. 


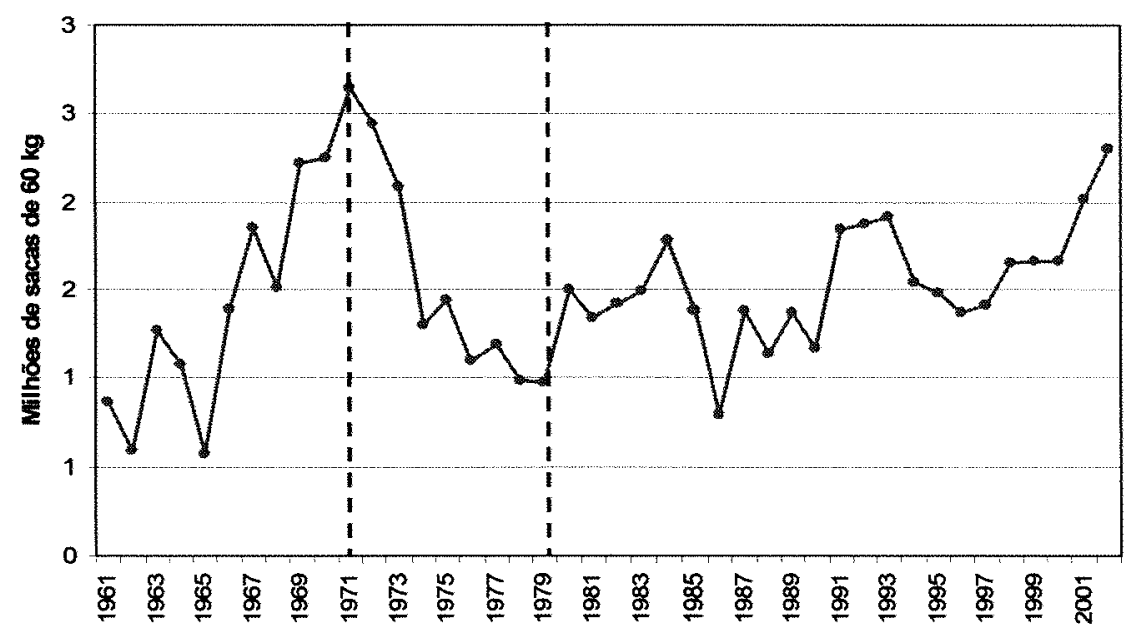

Figura 7 - Exportações brasileiras de café verde para a Itália Fonte: FAO (2003)

A Itália, juntamente com a Alemanha, são os maiores exportadores de café industrializado do mundo. Estes países adquirem cafés verdes e os processam e reexportam com maior valor agregado. Segundo estudos realizados pela Coffee Business (2003), em dados da Comtrade (FAO/ONU), a Itália consegue a cotação de US\$ 4,43/kg de café exportado ${ }^{17}$, contra US\$1,07/kg de café importado, apurado em média no Brasil. A maior ênfase das exportações italianas é o produto processado pronto para gerar café expresso. Assim, a Itália é conhecida como um dos países que vende cafés mais caros do mundo, utilizando o café brasileiro como componente principal para o blend italiano. $\mathrm{O}$ país é referência para os consumidores que buscam uma bebida diferenciada ou novas tecnologias no preparo dos cafés.

Na figura 5 é possível observar que o market share do Brasil no abastecimento da Itália com café aumentou entre 1961 e 1971, chegando a aproximadamente $90 \%$ das importações italianas da matéria-prima. A partir de 1971 houve tendência nítida de queda na participação brasileira, chegando a representar pouco mais de $30 \%$ do total de cafés importados pela Itália em 2001.

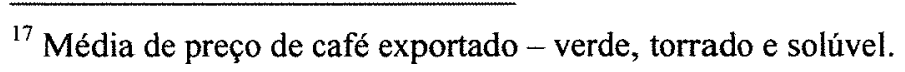


O consumo interno italiano nos últimos 12 anos tem aumentado (tabela 2), passando de 4,5 milhões de sacas consumidas no ano safra 1990/91 para 5,2 milhões em 2001/02, conforme estatísticas do USDA.

A indústria torrefadora italiana tem sido impulsionada pelo grande investimento em qualidade e marketing que tem sido feito nas marcas dos cafés italianos. Isto tem mantido a Itália como um potencial mercado para os países fornecedores (dada a demanda de matéria-prima) e tem levado os italianos a experimentarem cada vez mais os cafés processados por eles mesmos. O consumo per capita italiano aumentou de 4,8 $\mathrm{kg} / \mathrm{habitante} / \mathrm{ano}$ em 1990/91 para 5,4 kg em 2001/02 (tabela 3).

\subsection{França}

As exportações brasileiras para o mercado francês são caracterizadas por flutuações expressivas, como pode ser visto na figura 8, apresentada a seguir. Estas flutuações estão intimamente associadas à sensibilidade do mercado francês aos preços do café brasileiro.

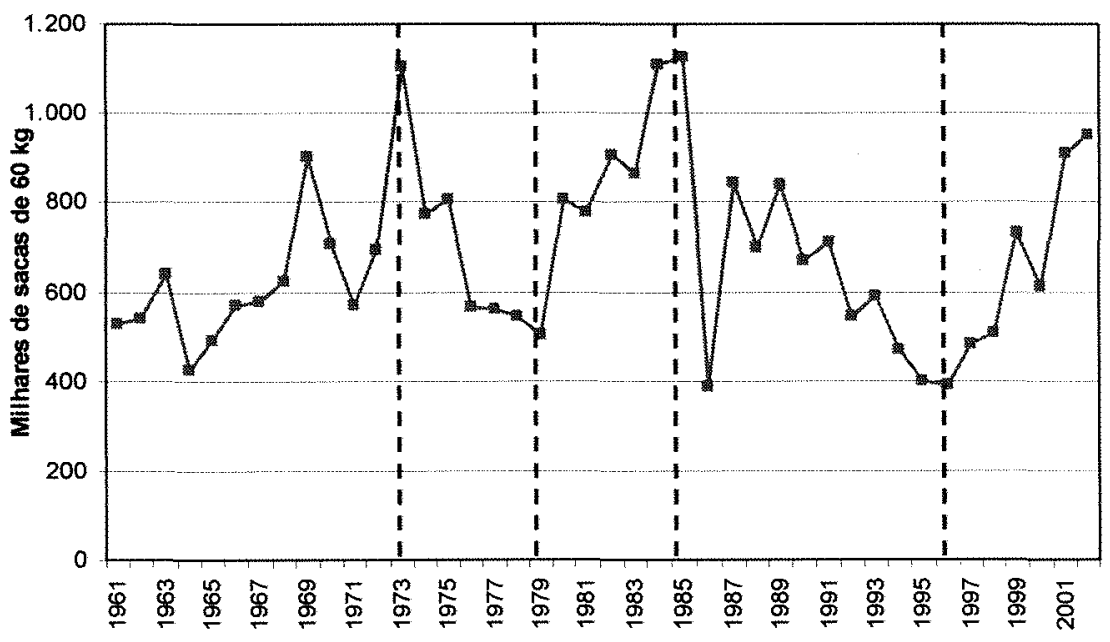

Figura 8 - Exportações brasileiras de café verde para a França Fonte: FAO (2003)

O volume crescente de cafés exportados para a França no periodo de 1961 a 1973 coincide com uma fase de preços baixos do café brasileiro (figura 1). A queda nítida das 
importações francesas de café brasileiro de 1974 a 1979 reflete a forte elevação dos preços do café brasileiro nesse período. Entre 1980 e 1985 (período caracterizado por um novo ciclo de preços baixos) é possível observar (figura 8) expansão das exportações brasileiras de café para a França. A queda brusca das importações francesas de café do Brasil, em 1986, está ligada à quebra de safra brasileira ${ }^{18}$, quando o volume total ofertado foi bem menor. De modo geral, a flutuação com períodos de altos e baixos volumes de café exportados para a França após 1986, segue da mesma maneira os patamares de preços do café brasileiro. Portanto, há uma íntima ligação entre os volumes de café exportados do Brasil para a França e os níveis de preços do café brasileiro.

Analisando o market share do café brasileiro no mercado francês (figura 5), é possível observar que a participação das exportações brasileiras de café é bem flutuante ao longo do tempo e segue uma trajetória bem semelhante às exportações brasileiras de café verde para este mercado (figura 8). A participação brasileira no mercado francês, que era de aproximadamente 16\% em 1961, atingiu cerca de 25\% em 1973 e 1985, ficando ao redor de $18 \%$ em 2001.

O consumo interno de café na França diminuiu na primeira metade da década de 90, recuperando-se parcialmente a partir de 1995 (tabela 2). A França apresenta consumo per capita de café inferior ao da Alemanha e Holanda, com flutuações em torno de 5,5 $\mathrm{kg} /$ habitante/ano nos últimos anos (tabela 3 ).

\subsection{Japão}

O Japão tem mostrado crescimento expressivo e consistente nas importações de café brasileiro desde o início da década de 70 (figura 9).

\footnotetext{
${ }^{18}$ No ano de 1986 o Brasil exportou somente cerca de 8 milhões de sacas de café verde contra aproximadamente 17 milhões de sacas nos anos de 1985 e 1987, reflexo da quebra de safra na produção brasileira.
} 


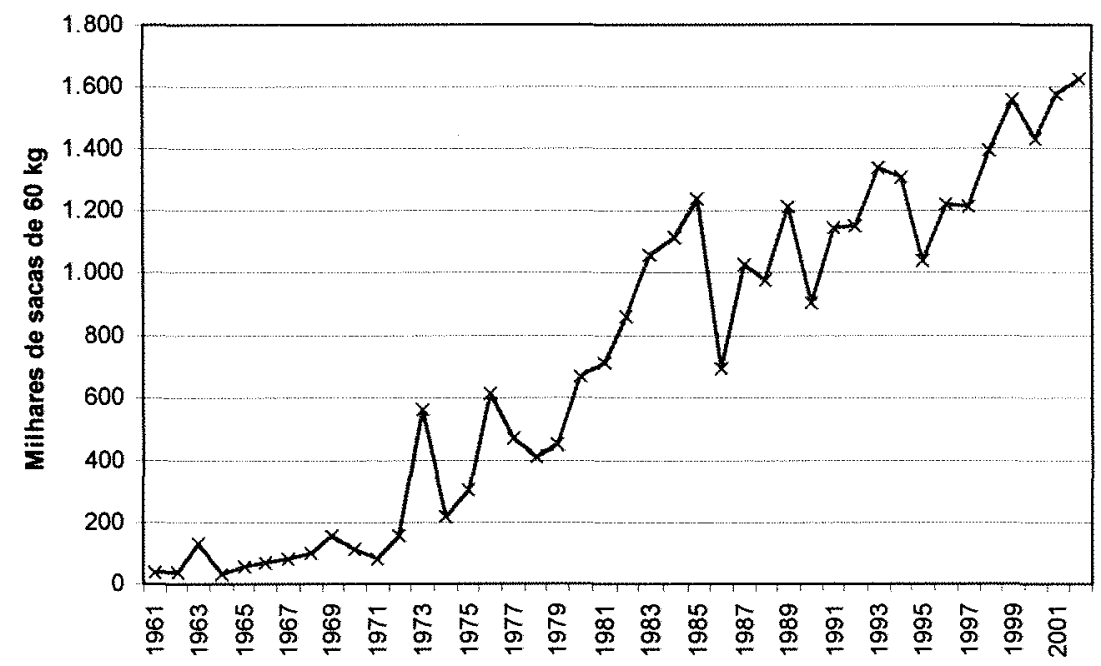

Figura 9 - Exportações brasileiras de café verde para o Japão

Fonte: FAO (2003)

É possível observar que o Brasil exportou cerca de 600 mil de sacas de $60 \mathrm{~kg}$ para o mercado japonês em 1973 e, em 2001, chegou à marca de 1,6 milhão de sacas de café.

Estimativas da Coffee Business (2003), a partir de dados do MDIC, dão conta de que o Japão é o mercado que paga melhor pelo café brasileiro. O preço médio pago pelos japoneses na saca de café brasileira foi de US $\$ 58,71$, utilizando uma média de 12 meses, calculada entre abril de 2002 e março de 2003 . O café nas mesmas condições foi vendido aos EUA por US\$ 44,41 e US\$ 51,03 para a Alemanha.

Voltando à figura 5 é possível observar que o café brasileiro cresceu seu market share no Japão até 1985, quando atingiu $32 \%$ do total de cafés importados pelo mercado japonês. Após 1985, a participação brasileira tem-se mantido em patamares próximos a $25 \%$ das importações totais de café verde no Japão.

O consumo interno de café no Japão tem apresentado uma forte tendência de crescimento (tabela 2), tendo passado de 5,4 milhões de sacas em 1990/91 para 7 milhões de sacas consumidas internamente em 2001/02. Em termos per capita, houve crescimento no consumo entre 1990/91 e 2001/02, tendo passado de 2,6 kg/habitante/ano para $3,3 \mathrm{~kg}$, respectivamente (tabela 3 ). 
O café no Japão disputa com vantagem a preferência dos jovens com relação aos refrigerantes. Estimativas relatadas por Saes \& Farina (1999) sugerem que um terço do consumo de café é em lata, pronto para beber, frio ou quente (estimado em 330 milhões de latas/ano), vendidos em máquinas automáticas. O mercado é disputado por granáes empresas, em que quase $50 \%$ do market share é da Coca-Cola.

A infra-estrutura de distribuição da bebida no país também tem sido favorável à expansão do consumo. A facilidade do consumidor japonês até as máquinas de café expresso, e também às bebidas geladas enlatadas, tem ajudado a disseminação do consumo de café neste mercado.

\subsection{Brasil}

O mercado doméstico é um grande consumidor do café produzido no Brasil. Ainda que o café seja um produto tradicionalmente exportável, o consumo da bebida, especialmente na forma de infusão, faz parte do cotidiano do brasileiro, mesmo sob as condições tropicais de clima em que vive a maior parte da população brasileira.

Segundo dados do CECAFÉ (Conselho dos Exportadores de Café do Brasil) e da ABIC, no ano safra de 2001/2002 o Brasil produziu 31,3 milhões de sacas de café verde e exportou 23,3 milhões de sacas (referente ao café cru, solúvel e torrado). O consumo interno de café em 2002 foi de 14 milhões de sacas de café verde.

A figura 10 apresenta a evolução do consumo brasileiro de café, total e per capita, no período de 1960 a 2002. É possível definir três períodos distintos de consumo interno de café, como pode ser observado através das linhas pontilhadas. 


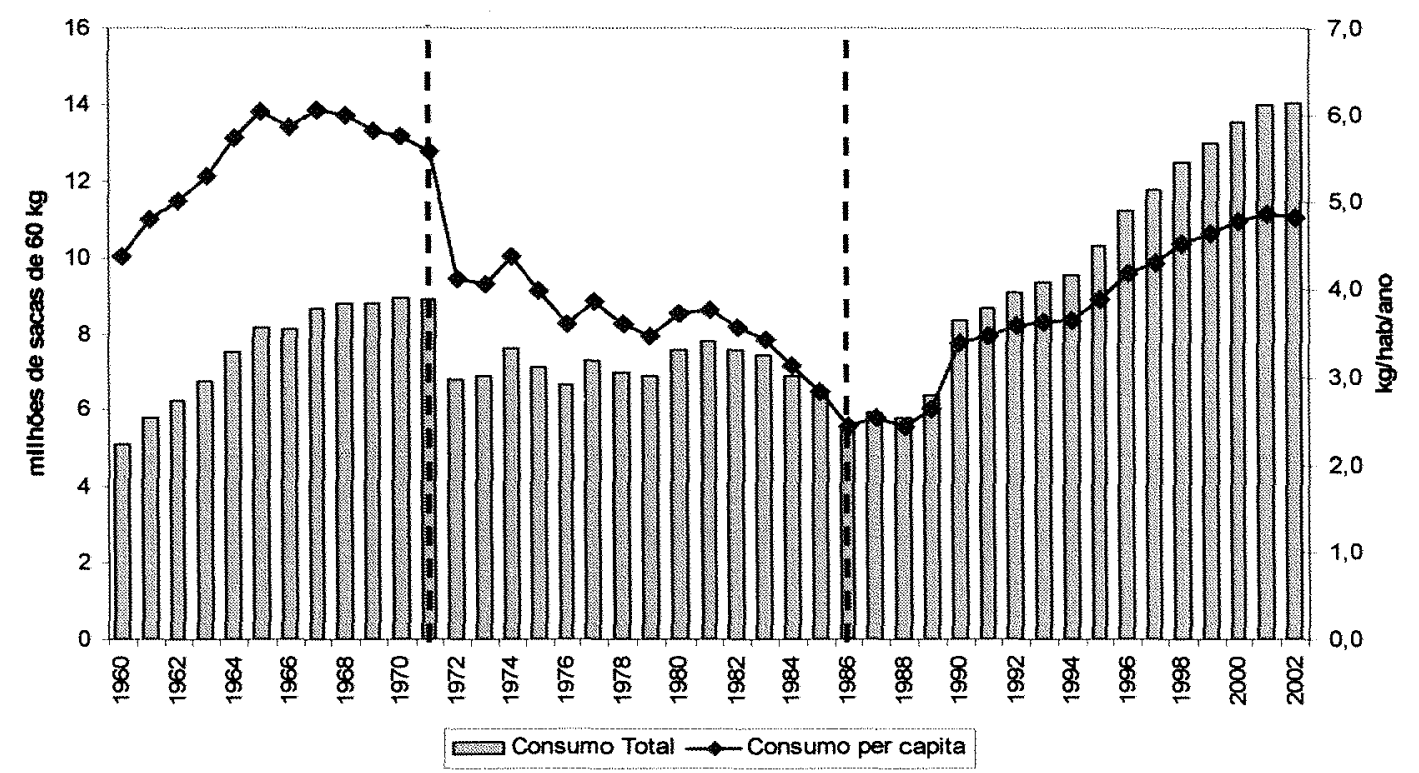

Figura 10 - Consumo brasileiro de café verde (total e per capita) Fonte: IBC (1989); ABIC (2003)

É possível notar um crescimento expressivo na quantidade consumida total no primeiro período destacado, entre 1960 e 1971. De 1972 a 1986 ocorreu uma estagnação do consumo total e queda nítida no consumo per capita. De 1987 a 2002 percebe-se um movimento crescente na retomada do consumo interno de café verde.

O aumento no consumo de café na década de 1960 (incluída no $1^{\underline{0}}$ período) deveuse ao incentivo da política governamental (Campanha para o Aumento do Consumo Interno do Café). Durante este período, houve grande impulso à modernização da indústria de torrefação e moagem; momento em que o incentivo ao consumo era via subsídio à matéria-prima, em função da capacidade instalada. Juntamente com os programas de suporte ao setor industrial, estabeleceu-se um programa de estímulo ao consumo interno, objetivando diminuir a pressão do excesso de oferta de café verde sobre os preços.

O decréscimo do consumo total e per capita de café no Brasil no período de 1972 a 1986 ( $2^{\circ}$ período) é explicado em grande parte por dois fatores: o aumento real de preços no mercado interno (com o fim do subsídio que existia) e as mudanças nos padrões alimentares (em parte devido ao crescimento no consumo de outras bebidas e em parte 
associada à deterioração da qualidade do café consumido no mercado nacional). Todo o Sistema Agroindustrial (SAG) do café pagou um preço elevado pela imagem negativa da bebida, criada pelas práticas abusivas de mistura de palha, cevada, milho e outras impurezas na composição da matéria-prima da torrefação.

A partir da segunda metade da década de 1980, representantes do setor produtor juntamente com a ABIC e empresas associadas reverteram a tendência de queda no consumo interno de café após um grande esforço pró-qualidade e criação do selo de pureza para o café. Portanto, o aumento do consumo no terceiro período (1987 a 2001) é devido, em parte, às ações de fiscalização e melhoria da qualidade promovida pela ABIC, bem como o sucesso do Plano Real.

Pode-se observar, na figura 10, que a partir de 1986 a trajetória do consumo interno per capita torna-se ascendente, chegando a 4,9 kg/habitante/ano em 2001 contra $2,4 \mathrm{em}$ 1986, refletindo uma conquista do setor cafeeiro, uma vez que as ações que denegriram a imagem do produto exigiram esforços conjuntos para esta mudança de contexto. A conquista do consumidor é um processo educativo continuado e, acima de tudo, trata-se de uma estratégia competitiva que envolve investimentos, cujo retorno vem em longo prazo e dependem da continuidade da estratégia.

A antiga estrutura do mercado interno possuía características de um oligopólio homogêneo com curva de demanda quebrada. Havia barreiras à entrada no mercado torrefador $^{19}$, existiam várias empresas atuantes (a maioria de pequeno porte) e nenhuma delas afetava isoladamente os preços do mercado. As empresas apresentavam alta concentração por mercado local. Porém, não havia estímulos para a melhoria da qualidade do café torrado, uma vez que o produto era tratado como homogêneo pelo consumidor (não havia diferenciação de preços devido ao tabelamento praticado) e o IBC subsidiava a torrefação oferecendo a matéria-prima, muitas vezes de baixa qualidade.

Com o fim do controle do IBC sobre a entrada de novas empresas no setor e o fim do tabelamento de preços imposto pelo governo houve um rearranjo na indústria de

\footnotetext{
${ }^{19}$ O IBC controlava o movimento de entrada e saída de empresas de torrefação. Havia estímulo para a indústria mas esta coordenação era feita pelo órgão de modo a garantir políticas de estabilização da oferta interna e externa sustentáveis. Desta forma, a indústria de torrefação foi incorporada ao sistema regulatório, pois o consumo interno depende do processamento.
} 
torrefação marcado por uma notável redução das pequenas torrefadoras e maior inserção e concentração da atividade nas empresas multinacionais.

Segundo informações da ABIC, o Brasil possuía 1593 indústrias de torrefação no ano de 1998 e 1321 torrefações em 2002. Esta redução está associada à estratégia das grandes empresas multinacionais de expelir as empresas marginais do mercado, colocando preços supostamente menores do que o custo médio destas últimas, uma vez que os custos médios de produção das empresas líder são geralmente menores.

Atualmente, o mercado apresenta características de um oligopólio diferenciado com forte inserção de empresas de torrefação multinacionais, uma grande discriminação de preços (cada empresa compõe seu próprio blend) e barreiras naturais para as pequenas empresas industriais no mercado nacional. Existe uma demanda emergente pela diferenciação de cafés, denominações de origem e qualidade que acentua a discriminação de preços no varejo.

Devido às quebras de tendência evidenciadas na figura 10 , os modelos 1 e 2 do Quadro 3 podem ser reestimados de modo a incluir variáveis dummies que captam essas mudanças. No Quadro 4 estão as novas regressões a serem estimadas juntamente com as regressões do Quadro 3. 


\begin{tabular}{|c|c|c|}
\hline Modelo 1 & $\mathrm{Cpc}=\alpha+\beta 1 \cdot \operatorname{Pr}+\beta 2 \cdot \operatorname{Pibpc}+\beta 3 \cdot \mathrm{Cpcdef}+\varepsilon$ & (23) \\
\hline Modelo 2 & $\operatorname{lnCpc}=\alpha+\beta 1 \cdot \ln \operatorname{Pr}+\beta 2 \cdot \ln P i b p c+\beta 3 \cdot \ln C p c d e f+\varepsilon$ & (24) \\
\hline Modelo 3 & $\begin{array}{l}\mathrm{Cpc}=\alpha+\beta_{1} \cdot \mathrm{D}_{1} \cdot \operatorname{Pr}+\beta_{3} \cdot \mathrm{D}_{1} \cdot \operatorname{Pibpc}+\beta_{4} \cdot \mathrm{D}_{1} \cdot \mathrm{Cpcdef}+\mathrm{D}_{2}+\beta_{5} \cdot \mathrm{D}_{2} \cdot \operatorname{Pr}+ \\
\beta_{7} \cdot \mathrm{D}_{2} \cdot \operatorname{Pibpc}+\beta_{8} \cdot \mathrm{D}_{2} \cdot \mathrm{Cpcdef}+\mathrm{D}_{3}+\beta_{9} \cdot \mathrm{D}_{3} \cdot \operatorname{Pr}+\beta_{11} \cdot \mathrm{D}_{3} \cdot \mathrm{Pibpc}+ \\
\beta_{12} \cdot \mathrm{D}_{3} \cdot \mathrm{Cpcdef}+\varepsilon\end{array}$ & $(32)$ \\
\hline Modelo 4 & $\begin{array}{l}\ln C p c=\alpha+\beta_{1} \cdot D_{1} \cdot \ln P r+\beta_{3} \cdot D_{1} \cdot \ln P i b p c+\beta_{4} \cdot D_{1} \cdot \ln C p c d e f+D_{2}+ \\
\beta_{5} \cdot D_{2} \cdot \ln P r+\beta_{7} \cdot D_{2} \ln \cdot \operatorname{Pibpc}+\beta_{8} \cdot D_{2} \cdot \ln C p c d e f+D_{3}+\beta_{9} \cdot D_{3} \cdot \ln P r+ \\
\beta_{11} \cdot D_{3} \cdot \ln P i b p c+\beta_{12} \cdot D_{3} \cdot \ln C p c d e f+\varepsilon\end{array}$ & (33) \\
\hline
\end{tabular}

Quadro 4 - Modelos de regressão múltipla utilizados nas estimativas da demanda interna pelo café verde brasileiro, considerando quebras de tendência

Sendo:

$\mathrm{Cpc}=$ Consumo brasileiro de café verde em termos per capita;

$\operatorname{Pr}=$ Preço recebido pelo produtor paulista pela saca de café de $60 \mathrm{~kg}$ beneficiada;

Pibpc $=$ PIB brasileiro em termos per capita;

Cpcdef $=$ Consumo brasileiro de café verde defasado em 1 período em termos per capita;

$\ln =$ logaritmo neperiano;

$\mathrm{D}_{1}, \mathrm{D}_{2}$ e $\mathrm{D}_{3}=$ variáveis binárias.

Os modelos 3 e 4 foram especificados incluindo variáveis binárias (dummies) de modo a isolar o efeito de duas quebras estruturais presentes na série temporal de consumo interno de café. Essas quebras estruturais definem as seguintes tendências na série:

i) 1960 a 1971 - tendência crescente;

ii) 1972 a 1986 - tendência decrescente;

iii) 1987 a 2002 - tendência crescente. 


\subsection{Outros mercados}

Deve-se destacar ainda a importância de outros mercados tradicionais como Espanha, Holanda e Reino Unido no consumo do café brasileiro. Naturalmente, em alguns momentos no tempo, houveram volumes exportados para outros países como Bélgica-Luxemburgo ou Grécia que foram superiores aos volumes importados pelos países consumidores em destaque neste trabalho. Os mercados selecionados para a discussão nesta dissertação foram escolhidos por terem sido os mais importantes nos últimos anos para o setor exportador cafeeiro e pela disponibilidade de dados confiáveis para toda a série histórica utilizada.

Em função do comportamento peculiar das séries de exportação inerentes a cada mercado estudado, faz-se necessário considerar diferentes modelos para as estimativas das demandas. Os períodos acidentados de maiores ou menores negócios são intrínsecos a cada série de exportação, por exemplo, o que acaba por exigir uma análise separada para cada mercado. 


\section{RESULTADOS E DISCUSSÃO}

\subsection{Análise da demanda externa}

Cada país estrangeiro analisado foi submetido à análise de regressão múltipla de 22 modelos não logaritimizados e os mesmos 22 modelos com os dados tomados em logaritmos (ver Quadro 2 do capítulo 2). No anexo C estão as tabelas 17 a 37 que apresentam os resultados das regressões estimadas para todos os modelos estudados, bem como as elasticidades preço e renda encontradas para cada estimativa.

As elasticidades são obtidas diretamente nos modelos logaritimizados e são calculadas conforme as equações (30) e (31) - apresentadas no capítulo 2 - para os modelos estimados com dados não logaritimizados. Fez-se necessário selecionar o melhor modelo estimado entre as 44 estimativas de cada país em questão.

A partir do modelo selecionado como melhor ajuste ${ }^{20}$ para o país estudado, no período de 1962 a 2002, foi re-estimado o mesmo modelo considerando dois outros períodos diferentes (1970 a 2002 e 1980 a 2002), de modo a observar possíveis mudanças nas elasticidades que possam estar ocorrendo ao longo do tempo. Portanto nas tabelas 17 a 37, em anexo, é possível observar também duas novas estimativas (1970-2002 e 1980 -2002) apresentadas após o modelo selecionado.

Desta forma, neste capítulo será apresentado e discutido somente o modelo selecionado para cada país analisado bem como as re-estimativas considerando os períodos, face às várias regressões estimadas.

\footnotetext{
${ }^{20}$ Considerou-se neste trabalho como "melhor ajuste", aquelas regressões que apresentaram maior nível de significância estatística nos parâmetros estimados (teste $t$ ), no teste $\mathrm{F}$ e o coeficiente de determinação mais elevado. As regressões tidas como melhores também se enquadram naquelas que não apresentaram autocorrelação serial nos resíduos.
} 
Os resultados das regressões estimadas para os mercados estudados são coincidentes no que diz respeito à elasticidade-preço da demanda. A demanda por café verde brasileiro nos mercados estudados é sempre inelástica a preços.

No decorrer deste trabalho, os modelos propostos também foram estimados considerando a variável população como uma das variáveis explicativas. No entanto, optou-se por excluírem essas regressões do contexto do trabalho pelas seguintes razões:

i) Não foram observados bons ajustes econométricos considerando a população nos modelos de regressão;

ii) Constatou-se que não é aconselhável incluir a população como variável explicativa, pois há alta correlação entre população e PIB, o que costuma gerar problemas de multicolinearidade entre as variáveis nas regressões.

iii) A demanda em condições normais é influenciada por indivíduos que têm renda e propensão a gastar e não pela população como um todo, que leva em consideração também os indivíduos que não têm disponibilidade de recursos.

O Quadro 5 apresenta resumidamente, as elasticidades preço e renda obtidas dos modelos estimados (período de 1962 a 2002) que apresentaram os melhores ajustes para cada mercado estrangeiro analisado. 


\begin{tabular}{|llcc|}
\hline Mercado & Modelo selecionado & Ep & Er \\
\hline EUA & $\mathrm{Y}=\alpha+\beta_{1} \cdot \operatorname{Pr}+\beta_{3} \cdot \operatorname{Pib}+\beta_{4} \cdot \mathrm{Ydef}+\varepsilon$ & $-0,29$ & $-0,68$ \\
Alemanha & $\mathrm{Y}=\alpha+\beta_{1} \cdot \operatorname{Pr}+\beta_{3} \cdot \mathrm{Pib}+\beta_{4} \cdot \mathrm{Ydef}+\varepsilon$ & $-0,22$ & 0,40 \\
Itália & $\mathrm{Y}=\alpha+\beta_{1} \cdot \operatorname{Pr}+\beta_{2} \cdot \mathrm{Pcs}+\beta_{3} \cdot \mathrm{Pib}+\beta_{4} \cdot \mathrm{Ydef}+\varepsilon$ & $-0,41$ & 0,23 \\
França & $\ln \mathrm{Ypc}=\alpha+\beta_{1} \cdot \operatorname{lnPr}+\beta_{2} \cdot \ln \mathrm{Pcs}+\beta_{3} \cdot \ln \mathrm{Pibpc}+\beta_{4} \cdot \ln Y \operatorname{defpc}+\varepsilon$ & $-0,75$ & $-0,15$ \\
Japão & $\mathrm{Ypc}=\alpha+\beta_{1} \cdot \operatorname{Pr}+\beta_{2} \cdot \mathrm{Pcs}+\beta_{3} \cdot \mathrm{Pibpc}+\beta_{4} \cdot \mathrm{Ydefpc}+\varepsilon$ & $-0,46$ & 1,01 \\
\hline
\end{tabular}

Quadro 5 - Elasticidades preço e renda obtidas nos modelos selecionados como melhores estimativas para os mercados estrangeiros estudados (periodo de 1962 a 2002)

Fonte: dados da pesquisa e tabelas $17,21,25,32$ e 35 , em anexo

Observando o Quadro 5, é possível perceber uma variação na magnitude das elasticidades preço calculadas para os mercados estrangeiros, variando de $-0,22$ na Alemanha a $-0,75$ na França. Elasticidade preço da ordem de $-0,22$ indica que uma variação em $1 \%$ no preço do café comercializado em tal mercado é acompanhada de uma variação da demanda no sentido contrário de $0,22 \%$.

Nota-se que as elasticidades-preço calculadas nos modelos selecionados são mais elevadas em módulo que os valores obtidos nos trabalhos pioneiros como os de Kingston (1939) e Finageiv (1976), que embora tenham avaliado a demanda global, encontraram elasticidades-preço da ordem de $-0,14$ e $-0,11$, respectivamente.

A elasticidade-preço calculada para o modelo selecionado para o mercado italiano $(E p=-0,41)$, pouco divergiu da estimativa realizada por Viana et al. (2003) quando se obteve elasticidade-preço igual a $-0,56$, também analisando a demanda italiana. No entanto, o mesmo autor encontra a elasticidade-preço igual a $-0,02$ para o mercado norteamericano, destoando bastante da elasticidade-preço do modelo selecionado neste trabalho para a demanda por café brasileiro nos Estados Unidos. 
No tocante às elasticidades-renda calculadas, observa-se grande variação entre os valores encontrados para os mercados estudados. Os valores encontrados definem o café verde brasileiro como um bem normal na Alemanha, Itália e Japão e como bem inferior nos Estados Unidos e França.

A maioria das elasticidades-renda apresentadas no Quadro 5 divergem dos resultados de Viana et al. (2003), que estudou a demanda por cafés de diversas origens, separadamente por mercado. No entanto, a elasticidade-renda calculada para o Japão (Er $=1,01$ ) é semelhante à estimativa realizada por este autor, que foi igual a 1,09 .

Com exceção ao trabalho de Viana et al. (2003), todos os trabalhos apresentados resumidamente no Quadro 1 são comuns em ressaltar que o café é um bem normal nos EUA quando a demanda norte-americana é estimada incluindo os cafés de todas as origens, e é um bem inferior quando trata-se da demanda norte-americana pelo café brasileiro. A elasticidade-renda calculada para o modelo selecionado norte-americano ( $\mathrm{Er}$ $=-0,68)$ é coerente com tais observações.

De modo a considerar a importância das re-exportações de café verde nas estimativas da demanda estrangeira pelo café brasileiro, optou-se por incluí-las como variável independente nos modelos selecionados. Estas estimativas foram realizadas somente para os Estados Unidos, Alemanha e França por apresentarem volumes relevantes de cafés verdes re-exportados, conforme os dados da FAO, apresentados em anexo na tabela 16.

Os resultados destas estimativas encontram-se no anexo $\mathrm{C}$, sucedidos da letra $\mathrm{R}$, juntamente com as demais regressões estimadas para cada mercado estudado. Tais regressões não melhoraram as estimativas anteriores. No caso norte-americano, a inclusão das re-exportações apresentou sinal negativo para esta variável (ver modelo 10.R na tabela 17 do anexo $\mathrm{C}$ ), indicando relação inversa com a demanda norteamericana, dificultando a análise deste resultado. Para a Alemanha, a inclusão da variável re-exportações foi altamente significativa e com sinal positivo (esperado) - modelo 10.R na tabela 21 -, no entanto, houve comprometimento da significância estatística da variável preço. Para o mercado francês, a variável re-exportações não foi estatisticamente significativa (modelo 22.R na tabela 32). 
Finalmente, todos os modelos selecionados para os mercados estrangeiros também foram submetidos a re-estimativas incluindo uma variável dummy especificamente para o ano de 1986. Este procedimento foi adotado devido a esta observação destoar demasiadamente das demais em todos os mercados. O ano de 1986 foi crítico na oferta de cafés brasileiros, como conseqüência da forte seca ocorrida. $\mathrm{O}$ impacto deste choque de oferta pode ser mais bem visualizado na figura 5 no capítulo 3. É possível perceber uma nítida queda no market share do Brasil no ano de $1986 \mathrm{em}$ todos os mercados estudados, o que justificou a inclusão da binária para este ano nos modelos selecionados.

De maneira geral, a inclusão da dummy para o ano de 1986 como variável independente nos modelos selecionados não apresentou melhorias nas estimativas selecionadas para os mercados estudados ${ }^{21}$. Foi observado um baixo nível de significância da variável binária para 1986 e/ou comprometimento da significância estatística das demais variáveis explicativas nos mercados. Os resultados das regressões dos modelos selecionados que incluíram a binária para 1986 estão apresentados também no anexo $\mathrm{C}$, nos modelos sucedidos da letra $\mathrm{D}$.

${ }^{21}$ Ver modelos $10 . \mathrm{D}$ na tabela $17,10 . \mathrm{D}$ na tabela $21,11 . \mathrm{D}$ na tabela 25,22 .D na tabela 32 e 22 .D na tabela 35. 


\subsubsection{EUA EN $^{22}$}

De maneira geral, os modelos utilizados para se estimar a demanda norte-americana pelo café brasileiro (apresentados em anexo nas tabelas 17 a 20) não apresentaram bons resultados quando se incluem os preços de outras bebidas, do suco de laranja e o preço de outros cafés como alternativa de bebida substituta ${ }^{23}$. Os modelos com bebida alternativa que apresentaram melhores resultados econométricos e coeficientes com sinais esperados foram os modelos que incluem o preço do chá.

Alguns modelos estimados apresentaram sinais esperados nos coeficientes e bons resultados nas estimativas, como por exemplo, os modelos 3 a 7 e 9 (tabela 18) e 15 a 18 e 20 (tabela 20) com dados logaritimizados. No entanto, não foi obtido um elevado nível de significância para a bebida substituta nas estimativas norte-americanas.

Assim, o modelo 10 não logaritimizado (tabela 17) foi escolhido como o que melhor se ajustou na regressão por ter apresentado elevado nível de significância estatística em todas as variáveis explicativas.

A tabela 4 apresenta os resultados do melhor modelo estimado para a demanda norte-americana pelo café brasileiro (modelo 10) e as estimativas do mesmo modelo para os períodos de 1970 a 2001 (modelo 10.1) e 1980 a 2001 (modelo 10.2), também apresentados na tabela $17 \mathrm{em}$ anexo.

\footnotetext{
${ }^{22}$ Excepcionalmente nas regressões estimadas para os EUA, foram utilizados dados de 1962 a 2001 (40 observações) ao invés de 1962 a 2002 (41 observações) como realizado para os demais mercados, considerando a perda da observação de 1961 em todos os cálculos. A omissão desta observação deveu-se ao fato deste dado não estar disponível no momento em que as regressões para este mercado foram realizadas.

${ }^{23}$ Deve-se lembrar que a variável preço do café substituto (Pcs), adotada em alguns modelos também se trata de uma alternativa de bebida concorrente, doravante discutido entre os bens substitutos.
} 
Tabela 4. Resultado dos modelos de melhor ajuste nas regressões estimadas para a demanda norte-americana pelo café brasileiro

\begin{tabular}{|c|c|c|c|c|c|c|c|c|c|c|}
\hline \multicolumn{11}{|c|}{$Y=\alpha+\beta_{1} \operatorname{Pr}+\beta_{3} \mathrm{Pib}+\beta_{4} \mathrm{Ydef}+\varepsilon$} \\
\hline & & \multirow[t]{2}{*}{$\alpha$} & $\mathrm{Pr}$ & \multirow[t]{2}{*}{ Pib } & \multirow[t]{2}{*}{ Ydef } & Teste F & \multirow[t]{2}{*}{$\mathrm{R}^{2}$} & \multirow[t]{2}{*}{$\mathrm{h}$} & \multirow[t]{2}{*}{ Ep } & \multirow[t]{2}{*}{$\mathrm{Er}$} \\
\hline & & & & & & $\operatorname{Pr}>\mathrm{F}$ & & & & \\
\hline $1962-2001$ & Coef. & 6.361 .360 & $-7.469,26$ & -39.920 & 0,4333 & 37,21 & 0,7562 & 0,04 & $-0,29$ & $-0,68$ \\
\hline \multirow[t]{2}{*}{ (modelo 10) } & Teste $\mathbf{t}$ & 4,43 & $-3,59$ & $-3,75$ & 3,67 & $<0,0001$ & & & & \\
\hline & $\operatorname{Pr}>|t|$ & $<0,0001$ & 0,0010 & 0,0006 & 0,0008 & & & & & \\
\hline $1970-2001$ & Coef. & 5.892 .570 & $-6.080,62$ & -30.801 & 0,2714 & 8,12 & 0,4653 & 0,67 & $-0,28$ & $-0,71$ \\
\hline \multirow[t]{2}{*}{ (modelo 10.1) } & Teste $t$ & 4,27 & $-3,09$ & $-3,00$ & 1,85 & 0,0005 & & & & \\
\hline & $\operatorname{Pr}>|t|$ & 0,0002 & 0,0045 & 0,0057 & 0,0754 & & & & & \\
\hline $1980-2001$ & Coef. & 6.312 .845 & $-6.085,51$ & -30.190 & 0,1261 & 1,45 & 0,1949 & Ic. & $-0,21$ & $-0,82$ \\
\hline \multirow[t]{2}{*}{ (modelo 10.2) } & Teste $\mathbf{t}$ & 3,13 & $-1,45$ & $-1,90$ & 0,61 & 0,2608 & & & & \\
\hline & $\operatorname{Pr}>|t|$ & 0,0058 & 0,1651 & 0,0731 & 0,5473 & & & & & \\
\hline
\end{tabular}

Fonte: dados da pesquisa e tabela $17 \mathrm{em}$ anexo

Ic $=$ Inconclusivo

O modelo $10 \mathrm{com}$ dados não logaritimizados é significativo ao nível de $1 \%$, expresso pelo teste F. As variáveis estimadas preço (Pr), índice do PIB (Pib) e a importação de café verde brasileiro defasada (Ydef) são significativas a 1\% pelo teste te possuem os sinais esperados nos coeficientes estimados.

O coeficiente de determinação, observado na estimativa do modelo 10 , sugere que $75,6 \%$ da variação na importação norte-americana de café verde brasileiro esteja sendo explicada pelas variáveis independentes do modelo.

Assim como no modelo 10, em todas as equações estimadas para a demanda norteamericana pelo café brasileiro, foi possível observar que o café brasileiro é um bem inferior ${ }^{24}$, com bom nível de significância, como pode ser observado nos modelos 1 a 22 (logaritimizados e não logaritimizados), apresentados em anexo, nas tabelas 17 a 20 . A elasticidade renda calculada para o modelo 10 foi de $-0,68$. Isto significa dizer que para

\footnotetext{
${ }^{24} \mathrm{Um}$ bem é dito inferior $(\mathrm{Er}<0)$ quando aumentos na renda levam a quedas no consumo desse bem. Seguindo o mesmo raciocínio, é dito bem normal $(0<\mathrm{Er}<1)$ quando aumentos na renda levam a aumentos no consumo e é dito bem de luxo $(\mathrm{Er}>1)$ quando aumentos na renda levam a aumentos mais do que proporcionais no consumo.
} 
um aumento de $10 \%$ na renda, a demanda norte-americana pelo café verde brasileiro reduz em $6,8 \%$.

É possível observar nas tabelas 17 a 20 , em anexo, que a demanda norte-americana pelo café brasileiro é sempre inelástica a preços, embora tenham sido observadas elasticidades de $-0,11$ (modelo 22 logaritimizado) até $-0,42$ (modelo 4 logaritimizado), sendo portanto inelásticas em diferentes dimensões.

Em nenhum modelo estimado para a demanda norte-americana pelo café verde brasileiro foram observados valores no teste $\mathrm{h}$ fora do intervalo descrito no capítulo 2 na equação (29), ou seja, não há indícios da presença de autocorrelação positiva ou negativa nos testes realizados.

Ao re-estimar o modelo 10 considerando períodos menores foi possível observar que:

i) O nivel de significância tanto do teste $\mathrm{F}$, como do teste $\mathrm{t}$ para as variáveis estimadas diminui na medida em que se reduz o número de observações. No entanto, ainda foram observados elevados níveis de significância estatística nos testes;

ii) O coeficiente de determinação diminui acentuadamente no procedimento;

iii) A elasticidade-preço da demanda oscila pouco ao longo do tempo;

iv) A elasticidade-renda aumenta em módulo, ou seja, o café verde brasileiro é cada vez mais inelástico a renda e é sempre um bem inferior nos EUA;

v) As novas estimativas não apresentaram autocorrelação entre os resíduos.

As elasticidades preço (Ep) e renda (Er) calculadas são concordantes com o trabalho de Abaelu \& Manderscheid (1968), que encontrou Ep $=-0,21$ e Er $=-0,89$ ao estimar a demanda norte-americana por café brasileiro. Os valores positivos para elasticidade-renda obtidos na literatura e apresentados no Quadro 1, tratam da demanda norte-americana por cafés de todas origens e não somente do Brasil.

$\mathrm{O}$ valor encontrado para a elasticidade-preço também é semelhante às estimativas de Delfim Netto (1955) e Daly (1958) como pode ser observado no Quadro 1.

No capitulo 3, foi discutido que o café brasileiro perdeu market share nos EUA ao longo do tempo (figura 5), evidenciado pela tendência de queda das importações norte- 
americanas de café do Brasil ao longo do tempo. As elasticidades renda apresentadas na tabela 4 reforçam que a queda no desempenho do café brasileiro neste mercado está intimamente ligada ao fato do produto ter sido cada vez menos importante no consumo norte-americano.

\subsubsection{Alemanha}

Em anexo, encontram-se as tabelas 21 a 24 que apresentam as estimativas da demanda alemã pelo café verde brasileiro. A seguir, discutem-se os resultados encontrados que são comuns a todos os modelos especificados para este mercado.

As regressões estimadas para a demanda alemã pelo café verde brasileiro, de um modo geral, não foram boas sob o aspecto das bebidas substitutas. Somente as variáveis Pic (preço de importação de chá) e Pcs (preço do café substituto) apresentaram sinal (positivo) coerente com o esperado, em todas as estimativas que a incluíram, embora não tenham sido observados bons níveis de significância no teste t. Os modelos que incluem o preço de importação do chá e preço do café substituto são respectivamente os modelos 4 e 15 (não logaritimizados) e 11 e 22 (logaritimizados).

Diferentemente das estimativas norte-americanas, não foram observadas elasticidades-renda negativas. Contudo, houve modelos que apresentaram valores maiores que um, tratando-se de um bem de luxo (modelos 1, 2, 3, 12, 13 e 14 - não logaritimizados e logaritimizados). Nota-se uma grande variação na magnitude da elasticidade renda positiva dos modelos estimados para a Alemanha, variando de 0,31 (modelo 19 - logaritimizado) a 2,25 (modelo 14 - não logaritimizado).

Todas as elasticidades-preço encontradas atestam que a demanda por café verde brasileiro é inelástica a preços na Alemanha, ou seja, aumentos nos preços de importação do café verde pela Alemanha são acompanhados de variações no sentido contrário menos que proporcionais na demanda alemã. No entanto, a magnitude da elasticidade-preço nos modelos estimados é variável. Os valores calculados encontram-se entre $-0,49$ (modelo 19 - logaritimizado) e -0,13 (modelo 2 e 13 - não logaritimizados). 
A estatística $\mathrm{h}$ de Durbin, que testa a presença de autocorrelação, apresentou valores notavelmente elevados em alguns modelos estimados em logaritmo (modelos 4 , $9,10,11,15,20,21$ e 22), indicando a presença de autocorrelação positiva. Nos demais modelos da estimativa alemã, a estatística $h$ ou encontrou-se dentro do intervalo que indica ausência de autocorrelação, ou não foi possível definir se há ou não sua presença.

Os melhores resultados obtidos nas estimativas para o mercado alemão podem ser visualizados na tabela 5 que apresenta os resultados da análise de regressão múltipla para o modelo 10 não logaritmizado, bem como os modelos 10.1 e 10.2 que re-estimaram a demanda alemã considerando períodos menores.

Tabela 5. Resultado dos modelos de melhor ajuste nas regressões estimadas para a demanda alemã pelo café brasileiro

\begin{tabular}{|c|c|c|c|c|c|c|c|c|c|c|}
\hline \multicolumn{11}{|c|}{$\mathrm{Y}=\alpha+\beta_{1} \mathrm{Pr}+\beta_{3} \mathrm{Pib}+\beta_{4} \mathrm{Ydef}+\varepsilon$} \\
\hline & & \multirow[t]{2}{*}{$\alpha$} & $\overline{\mathrm{Pr}}$ & \multirow[t]{2}{*}{ Pib } & \multirow[t]{2}{*}{ Ydef } & Teste F & \multirow[t]{2}{*}{$\mathrm{R}^{2}$} & \multirow[t]{2}{*}{$\mathrm{h}$} & \multirow[t]{2}{*}{ Ep } & \multirow[t]{2}{*}{$\overline{E r}$} \\
\hline & & & & & & $\mathrm{Pr}>\mathrm{F}$ & & & & \\
\hline $1962-2002$ & Coef. & 214.105 & $-2.051,20$ & 8.754 & 0,7441 & 29,12 & 0,7025 & Ic. & $-0,22$ & 0,40 \\
\hline \multirow[t]{2}{*}{ (modelo 10) } & Teste $\mathrm{t}$ & 0,49 & $-1,75$ & 1,60 & 4,70 & $<0,000 \mathrm{I}$ & & & & \\
\hline & $\operatorname{Pr}>|t|$ & 0,6286 & 0,0890 & 0,1183 & $<0,0001$ & & & & & \\
\hline $1970-2002$ & Coef. & -66.406 & $-1.747,19$ & 11.522 & 0,7391 & 20,51 & 0,6796 & Ic. & $-0,17$ & 0,53 \\
\hline \multirow{2}{*}{ (modelo 10.1) } & Teste $t$ & $-0,10$ & $-1,25$ & 1,42 & 4,12 & 0,0005 & & & & \\
\hline & $\operatorname{Pr}>|t|$ & 0,9244 & 0,2213 & 0,1650 & 0,0003 & & & & & \\
\hline $1980-2002$ & Coef. & 373.833 & $-4.626,40$ & 11.092 & 0,7130 & 12,31 & 0,6602 & Ic. & $-0,32$ & 0,48 \\
\hline \multirow[t]{2}{*}{ (modelo 10.2) } & Teste $t$ & 0,30 & $-1,57$ & 0,89 & 3,32 & 0,2608 & & & & \\
\hline & $\operatorname{Pr}>|t|$ & 0,7654 & 0,1338 & 0,3826 & 0,0036 & & & & & \\
\hline
\end{tabular}

Fonte: dados da pesquisa e tabela $21 \mathrm{em}$ anexo

Ic $=$ Inconclusivo

Pelo teste $F$, para o modelo 10 não logaritimizado, pode-se concluir que a significância conjunta dos coeficientes do modelo é de 1\%. Este nível de significância diminui nas estimativas dos modelos 10.1 e 10.2. Na estimativa do período maior (modelo 10), o coeficiente das variáveis preço do café brasileiro (Pr), índice do PIB (Pib) e a variável dependente defasada em um período (InYdef) foram significativos a 9, 12 e $1 \%$, respectivamente, e apresentaram sinais esperados nos coeficientes. 
É possível observar pelo $\mathrm{R}^{2}$ calculado na regressão que $70,25 \%$ da variação na importação alemã de café verde brasileiro pode ser explicada pelas variáveis que 0 modelo 10 sugere, apresentadas na tabela 5 .

A elasticidade renda obtida a partir do modelo 10 é de 0,40 (no período de 1962 a 2002), indicando que o café brasileiro importado pela Alemanha é um bem normal, sob tais condições. Ao longo do tempo, a elasticidade renda da demanda de café tem aumentado na Alemanha, passando a 0,53 no período de 1970 a 2002 e 0,48 no período de 1980 a 2002.

A recuperação do market share do café brasileiro no mercado alemão, após 1986 (figura 5, no capítulo 3), é condizente com as elasticidades renda calculadas para a Alemanha.

Com relação à elasticidade preço da demanda, é possível observar uma pequena variação nos valores calculados para os modelos 10, 10.1 e 10.2. Viana et al. (2003), ao estimar a demanda alemã por cafés de diversas origens, encontrou elasticidade-preço igual a $-0,36$, sendo levemente maior em módulo do que os resultados apresentados na tabela 5. A elasticidade renda calculada pelo mesmo autor é igual a $-0,35$ sendo, portanto, discordante da estimativa deste trabalho.

Não foi observada a presença de autocorrelação no modelo selecionado. A estatística h de Durbin calculada foi inconclusiva para os modelos selecionados.

\subsubsection{Itália}

As tabelas 25 a 28 , apresentadas em anexo, contêm os resultados das estimativas realizadas para a Itália. Constata-se o seguinte:

i) Todas as regressões realizadas para a Itália mostraram-se significativas a $1 \%$ no teste $\mathrm{F}$;

ii) Com relação às bebidas substitutas, nenhum modelo estimado apresentou sinal esperado para a variável preço da bebida substituta alternativa ao café, mostrando que, para a Itália, os preços do chá, suco de laranja e as outras 
bebidas não ajudam a explicar as importações italianas de café verde brasileiro;

iii) Os modelos que incluem a variável preço do café substituto (Pcs) mostraram-se coerentes com relação aos sinais esperados e apresentaram bons níveis de significância no teste t para variáveis explicativas;

iv) Exceção feita aos modelos 4 e 15 logaritimizados, todas as estimativas realizadas indicaram que a elasticidade renda observada foi positiva e menor do que 1, permitindo dizer que o café brasileiro no mercado italiano é um bem normal;

v) A demanda pelo café brasileiro é preço inelástica no mercado italiano, embora tenham sido observados diferentes valores para a elasticidade preço;

vi) Não foi observada autocorrelação na maioria dos modelos estimados. $O$ teste $\mathrm{h}$ de Durbin foi inconclusivo nos modelos 5, 6 e 17 logaritimizados e no modelo 11.2 não logaritimizado, como pode ser observado nas tabela 25 a 28 em anexo.

A tabela 6, apresentada a seguir, expressa os principais resultados do modelo de regressão considerado como a melhor estimativa da demanda italiana pelo café verde brasileiro (modelo 11 - não logaritimizado), bem como os modelos 11.1 e 11.2 que consideram os períodos separadamente. 
Tabela 6. Resultado dos modelos de melhor ajuste nas regressões estimadas para a demanda italiana pelo café brasileiro

\begin{tabular}{|c|c|c|c|c|c|c|c|c|c|c|c|}
\hline \multicolumn{12}{|c|}{$\mathrm{Y}=\alpha+\beta_{1} \mathrm{Pr}+\beta_{2} \mathrm{Pcs}+\beta_{3} \mathrm{Pib}+\beta_{4}$ Ydef $+\varepsilon$} \\
\hline & & \multirow[t]{2}{*}{$\alpha$} & \multirow[t]{2}{*}{$\operatorname{Pr}$} & Pcs & \multirow[t]{2}{*}{ Pib } & \multirow[t]{2}{*}{ Ydef } & Teste F & \multirow[t]{2}{*}{$\mathrm{R}^{2}$} & \multirow[t]{2}{*}{$\mathrm{h}$} & \multirow[t]{2}{*}{ Ep } & \multirow[t]{2}{*}{$\mathrm{Er}$} \\
\hline & & & & & & & $\operatorname{Pr}>\mathrm{F}$ & & & & \\
\hline $1962-2002$ & Coef. & 335.073 & $-3.723,6$ & $3.199,6$ & $4.714,4$ & 0,5252 & 21,40 & 0,70 & 0,01 & $-0,41$ & 0,23 \\
\hline \multirow[t]{2}{*}{ (modelo 11) } & Teste $\mathbf{t}$ & 1,28 & $-5,37$ & 4,44 & 2,25 & 5,4 & $<0,0001$ & 40 & & & \\
\hline & $\operatorname{Pr}>|t|$ & 0,2084 & $<0,0001$ & $<0,0001$ & 0,0303 & $<0,0001$ & & & & & \\
\hline $1970-2002$ & Coef. & 61.603 & $-2.904,6$ & $2.590,8$ & $5.568,4$ & 0,6397 & 17,08 & 0,70 & $-0,04$ & $-0,32$ & 0,30 \\
\hline \multirow[t]{2}{*}{ (modelo 11.1) } & Teste t & 0,10 & $-4,09$ & 2,89 & 1,31 & 4,96 & $<0,0001$ & 93 & & & \\
\hline & $\operatorname{Pr}>|t|$ & 0,9224 & 0,0030 & 0,0073 & 0,1993 & $<0,0001$ & & & & & \\
\hline $1980-2002$ & Coef. & 194.209 & $-4.268,0$ & $2.633,0$ & 10.044 & 0,3815 & 6,03 & 0,57 & Ic. & $-0,39$ & 0,61 \\
\hline \multirow[t]{2}{*}{ (modelo 11.2) } & Teste $\mathrm{t}$ & 0,18 & $-2,84$ & 1,27 & 1,30 & 1,74 & 0,0029 & 25 & & & \\
\hline & $\operatorname{Pr}>|t|$ & 0,8565 & 0,0108 & 0,2211 & 0,2097 & 0,0982 & & & & & \\
\hline
\end{tabular}

Fonte: dados da pesquisa e tabela 25 em anexo

Ic $=$ Inconclusivo

Observando a tabela 6, é possível perceber que mesmo tomando um período menor nas estimativas da demanda italiana por café brasileiro, o coeficiente de determinação se mantém satisfatório no modelo 11.1 (33 observações). Ao estimar o modelo 11.2, com 23 observações nota-se uma redução no $\mathrm{R}^{2}$.

A variável preço do café brasileiro (Pr) foi significativa a 1\% nas três estimativas apresentadas na tabela 6. O preço do café substituto (Pcs) e a importação italiana de café brasileiro defasada (Ydef), foram significativos a 1\% nos modelos 11 e 11.1 e o PIB (Pib) foi significativo a 3\% somente no modelo $11 \mathrm{com}$ dados não logaritimizados.

Com relação à elasticidade preço calculada, nota-se pouca variação nos valores calculados ao longo do tempo.

Embora o market share do café brasileiro na Itália tenha sido reduzido ao longo do tempo (figura 5 no capítulo 3), isto não fez com que o café brasileiro fosse menos desejado neste mercado, no que diz respeito ao valor das elasticidades-renda calculadas (tabela 6). A elasticidade renda observada permite dizer que o café brasileiro no mercado 
italiano é sempre um bem normal e seu valor aumenta ao longo do tempo, tornando-se cada vez mais elástico.

Pela estatística h, apresentada na tabela 6, é possível dizer que os modelos 11 e 11.1 com dados não logaritimizados não apresentam autocorrelação entre as variáveis envolvidas, ou seja, não se rejeita a hipótese nula de que não há autocorrelação de primeira ordem (positiva ou negativa), entre os resíduos da regressão. $O$ teste $h$ de Durbin é inconclusivo para o modelo 11.2.

\subsubsection{França}

As especificações dos modelos estimados bem como os resultados das regressões francesas podem ser observadas nas tabelas 29 a 32 em anexo.

Os modelos de regressão propostos que incluem a variável preço do suco de laranja concentrado como bebida substituta não puderam ser estimados para França e Japão, pois há uma lacuna na série temporal francesa de 15 anos (1961 a 1975) sem dados disponíveis na fonte utilizada (FAO) e a inexistência da mesma série para o Japão.

Nas estimativas do mercado francês, três considerações peculiares a este país podem ser observadas no tocante às bebidas substitutas estudadas:

i) O coeficiente da variável preço de importação de chá (Pic) apresentou-se coerente com o sinal esperado (positivo), mas não foi significativo a $10 \%$;

ii) A variável preço do café substituto (Pcs) apresentou-se coerente com o sinal esperado (positivo) em todos os modelos que incluíram esta variável e foi significativa em até $6 \%$;

iii) Em nenhum outro modelo que sugere alternativa de bebida substituta, exceto chá e o café substituto, foi observado sinal esperado no coeficiente estimado.

Tais constatações são um indicativo de que cafés de outras origens e o chá na França competem com o café brasileiro na preferência do consumidor.

A variável PIB não apresentou elevado nível de significância em nenhuma das regressões estimadas para a demanda francesa pelo café verde brasileiro. 
Em todos os modelos estimados para a França, foram observados baixos coeficientes de determinação $\left(R^{2}\right)$, indicando pouca influência das variáveis explicativas escolhidas na demanda francesa pelo café brasileiro.

Com relação à elasticidade renda calculada, é possível observar grande variação nos valores calculados para os diferentes modelos. $\mathrm{O}$ valor da elasticidade renda variou de 1,50 (modelo 22.2 - logaritimizado) a 0,49 (modelo 12 - não logaritimizado).

Todas as estimativas da elasticidade preço dão conta de que o café brasileiro é inelástico a preços na França. As elasticidades preço calculadas estão compreendidas entre os limites $-0,84$ (modelo 11 - não logaritimizado) e $-0,10$ (modelos 1 e 12 - não logaritimizados e modelo 1 - logaritimizado).

A tabela 7, apresentada a seguir, contém os resultados da regressão do modelo francês que melhor se ajustou aos dados bem como as re-estimativas do modelo selecionado (modelo 22 - logaritimizado) para os períodos de 1970 a 2002 (modelo 22.1) e 1980 a 2002 (modelo 22.2). 
Tabela 7. Resultado dos modelos de melhor ajuste nas regressões estimadas para a demanda francesa pelo café brasileiro

\begin{tabular}{|c|c|c|c|c|c|c|c|c|c|c|c|}
\hline \multicolumn{12}{|c|}{$\ln Y p c=\alpha+\beta_{1} \ln P r+\beta_{2} \ln P c s+\beta_{3} \ln P i b p c+\beta_{4} \ln Y \operatorname{defpc}+\varepsilon$} \\
\hline & & $\alpha$ & $\overline{\ln P r}$ & $\operatorname{lnPcs}$ & InPibpc & $\begin{array}{c}\text { InYdef } \\
\mathrm{pc}\end{array}$ & $\begin{array}{l}\text { Teste F } \\
\operatorname{Pr}>F\end{array}$ & $\overline{\mathrm{R}^{2}}$ & $\mathrm{~h}$ & $E p$ & Er \\
\hline $1962-2002$ & Coef. & 0,6673 & $-0,7459$ & 0,6922 & $-0,1460$ & 0,4260 & 4,28 & 0,3224 & $-0,07$ & $-0,75$ & $-0,15$ \\
\hline \multirow[t]{2}{*}{ (modelo 22) } & Teste $\mathrm{t}$ & 0,67 & $-2,31$ & 1,98 & $-0,91$ & 3,03 & 0,0062 & & & & \\
\hline & $\operatorname{Pr}>|t|$ & 0,5103 & 0,0270 & 0,0555 & 0,3711 & 0,0045 & & & & & \\
\hline $1970-2002$ & Coef. & 3,6126 & $-0,7893$ & 0,6307 & $-0,6914$ & 0,3193 & 4,70 & 0,4016 & Ic. & $-0,79$ & $-0,69$ \\
\hline \multirow[t]{2}{*}{ (modelo 22.1) } & Teste $\mathrm{t}$ & 1,59 & $-2,30$ & 1,66 & $-1,71$ & 1,91 & 0,0050 & & & & \\
\hline & $\operatorname{Pr}>|t|$ & 0,1238 & 0,0293 & 0,1082 & 0,0992 & 0,0660 & & & & & \\
\hline $1980-2002$ & Coef. & 7,8951 & $-0,7349$ & 0,4571 & $-1,5020$ & 0,2622 & 3,44 & 0,4332 & Ic. & $-0,73$ & $-1,50$ \\
\hline \multirow[t]{2}{*}{ (modelo 22.2) } & Teste $t$ & 1,15 & $-1,32$ & 0,63 & $-1,20$ & 1,23 & 0,0296 & & & & \\
\hline & $\operatorname{Pr}>|t|$ & 0,2646 & 0,2023 & 0,5353 & 0,2445 & 0,2347 & & & & & \\
\hline
\end{tabular}

Fonte: dados da pesquisa e tabela $32 \mathrm{em}$ anexo

Ic $=$ Inconclusivo

Pela tabela 7 é possível observar que as variáveis explicativas do modelo 22 (com dados logaritimizados) estão explicando conjuntamente apenas $32,24 \%$ da variação na demanda francesa pelo café verde brasileiro. No entanto, é possível observar um aumento no coeficiente de determinação nas estimativas do modelo 22.1 e 22.2. Este valor do coeficiente de determinação, notavelmente baixo, indica que as importações francesas de café verde brasileiro podem estar sendo explicadas por outras variáveis não consideradas no modelo, e ainda, que o fraco ajuste obtido no modelo possa estar associado às fortes oscilações na série temporal deste país evidenciada pelas quebras estruturais ao longo do tempo (figura 8 , no capítulo 3 ).

Os modelos 22 e 22.1 com dados logaritmizados foram significativos a $1 \%$ pelo teste $\mathrm{F}$ e o modelo 22.2 foi significativo a $3 \%$. Com relação aos coeficientes estimados, nota-se que as variáveis explicativas apresentaram os sinais esperados e bons níveis de significância, com exceção da variável PIB per capita $(\operatorname{lnPibpc})$. Nota-se ainda, na tabela 7 , que a significância estatística das variáveis diminui acentuadamente nas estimativas 
dos modelos 22.1 e 22.2 , sendo este último insatisfatório do ponto de vista da significância dos testes $t$ das variáveis explicativas.

$O$ valor absoluto da elasticidade renda calculada para os modelos apresentados na tabela 7 aumenta notavelmente ao longo do tempo, tornando a demanda francesa pelo café brasileiro do tipo renda-elástica ( $\mathrm{Er}=-1,50$ no modelo 22.2). No entanto, o sinal das elasticidades renda calculadas indicam que o café brasileiro é um bem inferior na França.

As fortes oscilações na série temporal francesa de market share do café brasileiro (figura 5 no capítulo 3) dificultam as considerações que podem ser feitas entre os resultados econométricos observados e o perfil da demanda francesa. Esta dificuldade é acentuada pelos baixos coeficientes de determinação observados nas regressões deste mercado. No entanto, é fato que ocorreu uma redução do market share do café brasileiro na França ao longo do tempo e existe uma forte tendência de aumento em módulo da elasticidade-renda (tabela 7), tornando a demanda francesa pelo café verde brasileiro cada vez mais elástica à renda, ressaltando que a demanda por café brasileiro na França varia no sentido contrário à variação na renda.

Com relação às elasticidades preço calculadas, nota-se uma mínima variação nas estimativas dos modelos 22.1 e 22.2. com relação ao modelo 22 . O valor da elasticidade preço observada no modelo $22 \mathrm{com}$ dados logaritmizados $(E p=-0,75)$, é o maior valor em módulo encontrado nas estimativas dos modelos selecionados (ver Quadro 5). Este resultado equivale a dizer que aumentos da ordem de $10 \%$ no preço do café brasileiro reduzem a demanda francesa pelo café brasileiro em $7,5 \%$, indicando a magnitude da inelasticidade neste mercado.

$\mathrm{O}$ teste $\mathrm{h}$ de Durbin apresentado na tabela 7 indica que não foi observada autocorrelação entre os resíduos da regressão.

De maneira geral, as estimativas realizadas para a França apresentaram baixo coeficiente de determinação, sugerindo cautela nas inferências a respeito deste mercado. Assim sendo, a discussão feita acerca do nível de significância dos parâmetros estimados nas regressões e do modelo como um todo tem limitações. 


\subsubsection{Japão}

Os modelos especificados para se estimar a demanda japonesa pelo café verde brasileiro (tabelas 33 a 36) apresentaram elevado coeficiente de determinação nas estimativas, variando de 0,7074 (modelo 22.2 - não logaritimizado) a 0,9395 (modelo 11 - logaritimizado), diferente do observado com as regressões para a França.

Analisando as bebidas substitutas ao café brasileiro no Japão é possivel observar nas tabelas 33 a 36, em anexo, que em todas as estimativas que envolveram a variável preço do café substituto (Pcs) apresentaram o sinal esperado e foram significativos em até $4 \%$, exceto os modelos 22.1 e 22.2 (não logaritimizados) que serão discutidos a seguir. Este resultado é uma evidência notável de que existe forte competição entre cafés de diferentes origens no Japão.

Nas estimativas realizadas para o Japão foi possível observar que tanto a elasticidade renda quanto a elasticidade preço apresentaram grande variação em suas magnitudes. Enquanto os mínimos valores das elasticidades renda e preço, respectivamente, foram da ordem de 0,52 (modelo 22.2) e $-0,84$ (modelo 22 logaritimizado), os máximos foram de 2,67 (modelos 16 e 22 - logaritimizados) e 0,02 (modelos 1, 2, 10, 12, 13 e 21 - logaritimizados).

Em todas as estimativas realizadas para o mercado japonês com dados não logaritimizados e logaritimizados em termos per capita, não foi observada autocorrelação pelo teste $\mathrm{h}$ de Durbin (tabelas anexas 35 e 36). Para os modelos estimados na tabela 34 em anexo (dados logaritmizados), o cálculo da estatística $h$ foi inconclusiva em todas as situações.

A tabela 8, a seguir, exprime a melhor estimativa da demanda japonesa pelo café verde brasileiro (modelo 22 - não logaritmizado), bem como as estimativas do mesmo modelo considerando períodos menores (modelos 22.1 e 22.2). 
Tabela 8. Resultado dos modelos de melhor ajuste nas regressões estimadas para a demanda japonesa pelo café brasileiro

\begin{tabular}{|c|c|c|c|c|c|c|c|c|c|c|c|}
\hline \multicolumn{12}{|c|}{$\mathrm{Ypc}=\alpha+\beta_{1} \operatorname{Pr}+\beta_{2} \operatorname{Pcs}+\beta_{3} \operatorname{Pibpc}+\beta_{4}$ Ydefpc $+\varepsilon$} \\
\hline & & \multirow[t]{2}{*}{$\alpha$} & \multirow[t]{2}{*}{$\mathrm{Pr}$} & \multirow[t]{2}{*}{ Pes } & \multirow[t]{2}{*}{ Pibpc } & \multirow[t]{2}{*}{ Ydefpc } & Teste F & \multirow[t]{2}{*}{$\mathrm{R}^{2}$} & \multirow[t]{2}{*}{$\mathrm{h}$} & \multirow[t]{2}{*}{ Ep } & \multirow[t]{2}{*}{$\mathrm{Er}$} \\
\hline & & & & & & & $\operatorname{Pr}>F$ & & & & \\
\hline $1962-2002$ & Coef. & $-0,0709$ & $-0,0009$ & 0,0006 & 0,0052 & 0,3157 & 102,05 & 0,9190 & $-0,64$ & $-0,46$ & 1,01 \\
\hline \multirow[t]{2}{*}{ (modelo 22) } & Teste t & $-1,07$ & $-2,93$ & 2,32 & 3,98 & 2,24 & $<0,0001$ & & & & \\
\hline & $\operatorname{Pr}>|t|$ & 0,2934 & 0,0059 & 0,0259 & 0,0003 & 0,0313 & & & & & \\
\hline $1970-2002$ & Coef. & $-0,0539$ & $-0,0009$ & 0,0006 & 0,0050 & 0,3224 & 43,94 & 0,8626 & $-1,07$ & $-0,40$ & 0,91 \\
\hline \multirow[t]{2}{*}{ (modelo 22.1) } & Teste $\mathrm{t}$ & $-0,44$ & $-2,41$ & 1,93 & 2,64 & 1,92 & $<0,0001$ & & & & \\
\hline & $\operatorname{Pr}>|t|$ & 0,6608 & 0,0226 & 0,0640 & 0,0134 & 0,0656 & & & & & \\
\hline $1980-2002$ & Coef. & 0,0254 & $-0,0016$ & 0,0013 & 0,0032 & 0,4665 & 10,88 & 0,7074 & $-0,26$ & $-0,43$ & 0,52 \\
\hline \multirow[t]{2}{*}{ (modelo 22.2) } & Teste t & 0,09 & $-2,03$ & 1,19 & 1,41 & 2,40 & $<0,0001$ & & & & \\
\hline & $\operatorname{Pr}>|t|$ & 0,9292 & 0,0570 & 0,2497 & 0,1768 & 0,0276 & & & & & \\
\hline
\end{tabular}

Fonte: dados da pesquisa e tabela $35 \mathrm{em}$ anexo

$\mathrm{Ic}=$ Inconclusivo

Pelo teste $\mathrm{F}$, pode-se dizer que as variáveis explicativas dos modelos 22 (dados não logaritmizados), 22.1 e 22.2 estão fortemente associadas às importações japonesas de café verde brasileiro no período estudado.

Os coeficientes de determinação mostraram-se elevados nas regressões apresentadas na tabela 8 , embora seja possível notar sua redução ao tomarmos menos observações nas estimativas. De maneira geral, os coeficientes de determinação $\left(R^{2}\right)$ observados nas regressões japonesas apresentaram os maiores valores quando comparados às regressões dos outros mercados estrangeiros.

Ao se analisar os coeficientes das variáveis separadamente no modelo 22 com dados não logaritmizados, é possível perceber que todos os coeficientes possuem sinal esperado. O preço do café brasileiro (Pr) e o PIB per capita (Pibpc) foram significativos a $1 \%$, enquanto o preço do café substituto (Pcs) e a variável defasada da demanda japonesa em termos per capita (Ydefpc) foram significativos a 3 e 4\%, respectivamente. Nos modelos 22.1 e 22.2 também são observados os sinais esperados, mas os níveis de significância estatística diminuem para as variáveis explicativas (tabela 8). 
As elasticidades renda calculadas para o mercado japonês indicam que o café verde brasileiro é um bem normal no Japão. É possível observar ainda que, ao longo do tempo, o valor da elasticidade renda tem diminuído acentuadamente. No entanto, mesmo havendo esta tendência, deve-se ressaltar que as elasticidades-renda calculadas para o mercado japonês são elevadas e estão relacionadas ao aumento do market share do café brasileiro no Japão ao longo do tempo, como pode ser observado na figura 5 do capítulo 3.

A demanda japonesa pelo café verde brasileiro é preço-inelástica como pode ser observado ainda na tabela 8 e tem se alterado pouco no tempo, ficando ao redor de $-0,4$.

Não foi observada autocorrelação entre os resíduos das regressões apresentadas na tabela 8, pelo teste h de Durbin.

\subsection{Análise da demanda doméstica}

A tabela $37^{25}$, em anexo, apresenta os resultados das regressões realizadas para a demanda doméstica brasileira de café verde (consumo interno). Os modelos estimados com variáveis binárias não apresentaram bons ajustes. Embora tenham sido incluídas as variáveis dummy nos modelos especificados, não foram observados sinais esperados na variável preço (D1Pr) como pode ser observado na tabela 37, em anexo.

O modelo 2 (logaritimizado, com dados per capita) foi o que melhor se ajustou aos dados na análise de regressão. Esse modelo sugere que a demanda doméstica brasileira (consumo interno) per capita de café verde seja explicada no período estudado (1961 a

${ }^{25}$ Nota para a tabela 37, em anexo: É possível perceber a presença das colunas $\sigma$ e $\sigma^{2}$ que são respectivamente o desvio padrão (calculado na análise de regressão) e a variância da variável defasada (Cdef e Cpcdef). Essas variáveis são fundamentais no cálculo da estatística $h$ de Durbin, que testa a presença de autocorrelação nos modelos estimados. Como os modelos 5 a 8 foram especificados incluindo variáveis binárias, faz-se necessário encontrar as variâncias da variável defasada em todas as dummies (D1Cdef, D2Cdef e D3Cdef), justificando assim a presença das colunas $\sigma_{1}, \sigma_{1}{ }^{2}, \sigma_{2}, \sigma_{2}{ }^{2}, \sigma_{3}$ e $\sigma_{3}{ }^{2}$. Nota-se, portanto, que a estatística $h$ é calculada por período $\left(h_{1}, h_{2}\right.$ e $\left.h_{3}\right)$ nos modelos com dummies. As elasticidades (preço e renda) calculadas seguem o mesmo raciocínio para tais modelos. 
2002) pelo preço (recebido pelo produtor paulista), o PIB per capita e a pela variável consumo per capita defasada. No entanto, o nível de significância estatística da variável InPibpc desse modelo (e de suas re-estimativas pra 1970 a 2002 e 1980 a 2002) são muito baixas. Assim, re-estimou-se esses modelos na forma semi-logaritmica, mantendo-se apenas Pibpc em logaritmo. Os resultados dos modelos 9, 10 e 11 comparados com os modelos 2, 3 e 4 apresentam melhores níveis da estatística t e valores próximos para Er e Ep.

A tabela 9 apresenta os resultados dos modelos 9,10 e 11, para os períodos de 1961 a 2002,1970 a 2002 e 1980 a 2002, respectivamente.

Tabela 9. Resultado dos modelos de melhor ajuste nas regressões estimadas para a demanda doméstica pelo café brasileiro

$\operatorname{lnCpc}=\alpha+\beta_{1} \operatorname{Pr}+\beta_{2} \ln$ Pibpc $+\beta_{3}$ Cpcdef $+\varepsilon$

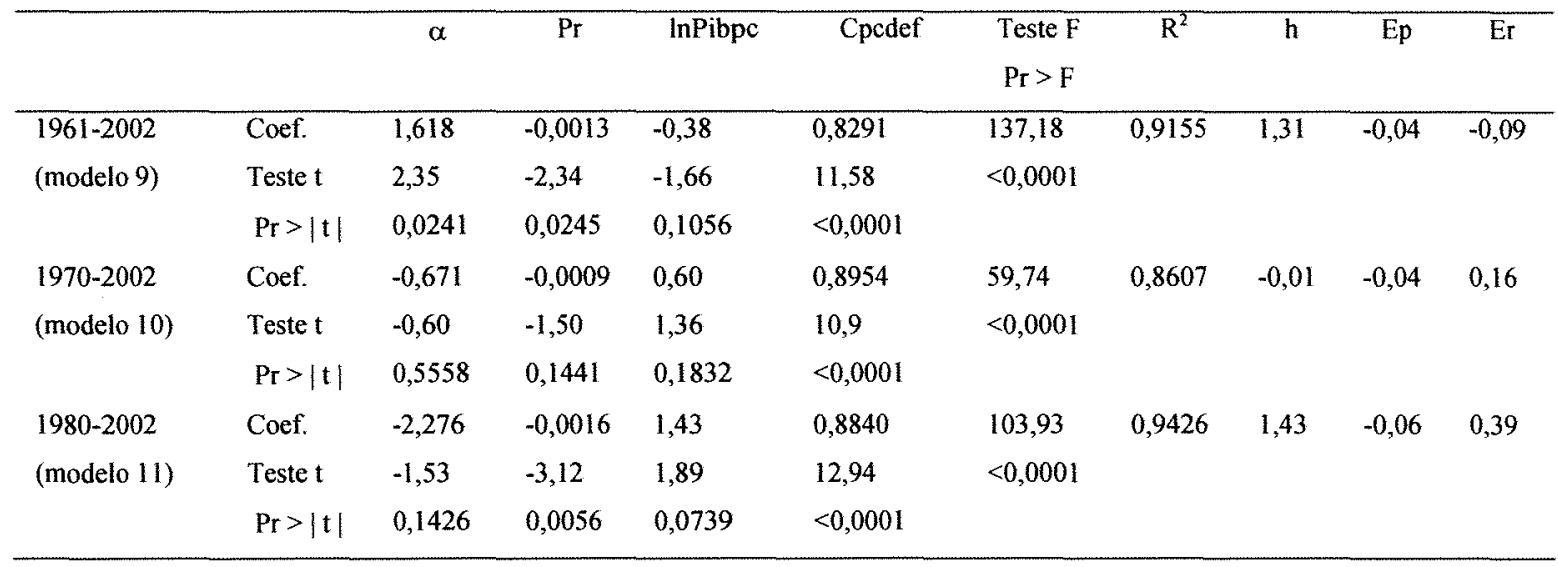

Fonte: dados da pesquisa e tabela $37 \mathrm{em}$ anexo

$\mathrm{Ic}=$ Inconclusivo

Os modelos 9,10 e 11 são significativos a $1 \%$ pelo teste $\mathrm{F}$. Nota-se ainda que os coeficientes $\mathrm{R}^{2}$ calculados são elevados.

O coeficiente da variável preço $(\ln P r)$ estimada nos modelos apresentou o sinal negativo esperado e mostrou-se significativo a 3,15 e $1 \%$ para os modelos 9,10 e 11 , respectivamente. $\mathrm{O}$ consumo per capita defasado (lnCpcdef) foi significativo a $1 \%$ nos 
três modelos e o PIB per capita (lnPibpc) não apresentou elevados níveis de significância estatística em nenhuma das estimativas apresentadas na tabela 9.

A elasticidade preço calculada praticamente não oscilou ao longo do tempo e a magnitude dos valores encontrados expressa a tamanha inelasticidade preço da demanda do café verde consumido pelo mercado doméstico. A elasticidade preço calculada para o modelo 9 indica que havendo um aumento em $10 \%$ no preço do café verde (recebido pelo produtor no Estado de São Paulo), tem-se uma redução no consumo interno de café verde de apenas $0,4 \%$ (medido em termos per capita e consumido pela indústria de torrefação). As estimativas da elasticidade preço da demanda interna de café realizadas por Carvalho (1974), Marques (1984) e Costa \& Silva (2003) foram respectivamente $-0,09$ a $-0,18$, $0,06 \mathrm{e}-0,07$. Essas estimativas são bem semelhantes às obtidas no presente trabalho.

No tocante à elasticidade renda, é possível observar que para a série completa de consumo interno (1961 a 2002) o café verde brasileiro consumido pela indústria de torrefação é um bem inferior $(\mathrm{Er}=-0,09)$. No entanto, o café passa a ser um bem normal ao se estimar o mesmo modelo para o período de 1970 a 2002 e, finalmente, considerando o período de 1980 a 2002 , o valor da elasticidade renda aumenta ainda mais $(\mathrm{Er}=0,39)$. Este resultado pode estar associado ao desempenho de recuperação do consumo per capita de café ocorrido após 1986 (evidenciado pela figura 10 no capítulo 3). Carvalho (1974) encontrou elasticidades renda iguais a 0,27 a 0,54 em suas estimativas para o período de 1964 a 1971. No trabalho de Costa \& Silva (2003), excluiuse a variável PIB per capita do modelo por ter apresentado elevada correlação com outras variáveis e os melhores ajustes também foram obtidos com os dados tomados na forma logarítmica.

Pela estatística h de Durbin, apresentada na tabela 9 para os modelos 9,10 e 11, rejeita-se a hipótese de presença de autocorrelação serial entre os resíduos com $95 \%$ de confiança, uma vez que os valores encontrados de $\mathrm{h}$ situam-se dentro do intervalo $-1,96 \leq$ $\mathrm{h} \leq 1,96$, conforme descrito no capítulo 2 (equação 29). 


\section{CONCLUSÕES}

Este trabalho analisou as demandas por café brasileiro nos mercados doméstico e externo no período de 1961 a 2002. A preocupação maior deste trabalho foi, primeiro, caracterizar os principais mercados consumidores de café brasileiro e, em seguida, estimar equações de demanda por esse produto nos mercados selecionados. Esses são os EUA, Alemanha, Itália, França, Japão e o próprio Brasil.

Constatou-se na literatura revisada que pouco se conhece sobre as elasticidades preço e renda da demanda de café em termos de mercados específicos e, além disso, os últimos trabalhos disponíveis indicam que a demanda externa global por café brasileiro tem aumentado sua elasticidade preço. No entanto, essas constatações devem ser referendadas considerando estimativas específicas para cada mercado, pois esses resultados poderão melhor fundamentar políticas e estratégias para aumentar a demanda por café brasileiro. Isto foi a principal motivação do presente trabalho.

O café sempre foi um produto importante na pauta de exportação brasileira, apesar de diminuir essa importância ao longo do tempo. Os EUA foram, até a década de 1990, o principal comprador externo do produto brasileiro. No entanto, os EUA têm perdido importância na compra de café brasileiro, bem como esse produto tem perdido market share no mercado norte-americano. Em 1961, os EUA absorveram 50,6\% das exportações de café brasileiro e em 2001 apenas 13,4\%. O Brasil foi responsável por $38,4 \%$ das importações norte-americanas de café verde em 1961, e em 2001 por 14,5\%. Esse fraco desempenho das exportações brasileiras de café para os EUA justificam a presença de elasticidade-renda negativa na demanda norte-americana por café brasileiro. Para o período de 1962 a 2001, a elasticidade-renda encontrada foi de $-0,68$, caracterizando o produto brasileiro como bem inferior nos EUA. Ao longo do 
tempo, a situação tem se deteriorado, pois nos períodos de 1970 a 2001 e 1980 a 2001 as elasticidades renda foram de $-0,71$ e $-0,82$, respectivamente. Tal situação poderia ser atribuída à diminuição da preferência norte-americana por café brasileiro em favor de outras bebidas. No entanto, nenhuma das regressões estimadas apresentou o sinal esperado (positivo) para a variável bebida alternativa. Esses resultados indicam que o mercado norte-americano não deve ser mais considerado como prioritário nas exportações de café verde e um novo produto deve ser considerado para exportar para esse país. Um exemplo desse novo produto são os chamados cafés especiais.

A Alemanha, recente país re-exportador de café verde, aumentou sua importância na absorção das exportações brasileiras de café, passando de 4,3\% em 1961 para 19,4\% em 2001. Atualmente, a Alemanha é o maior comprador de café brasileiro, e o produto brasileiro também têm aumentado o seu market share nas compras alemãs de café. Em 1961, o produto brasileiro representou 18,4\% das importações alemãs de café e em 2001, $29,1 \%$. Esses resultados estão coerentes com o fato da demanda alemã por café brasileiro apresentar elasticidade renda positiva e que tem aumentado ao longo do tempo. No período de 1962 a 2002, a elasticidade-renda da demanda alemã por café brasileiro foi de 0,40, passando a 0,53 no período de 1970 a 2002 e a 0,48 no período de 1980 a 2002 .

A Itália é o terceiro maior país importador de café do Brasil. Apesar das exportações brasileiras de café terem aumentado para a Itália no período de 1961 a 2002, o market share do Brasil nas importações totais de café pela Itália tem diminuído. Em 1961, o Brasil respondeu por 49\% das importações globais de café pela Itália e em 2001 por $32,8 \%$. O café brasileiro é um bem normal na Itália, com elasticidade-renda positiva e crescente ao longo do tempo. No período de 1962 a 2002, a elasticidade-renda da demanda italiana por café brasileiro foi de 0,23 , passando a 0,30 no período de 1970 a 2002 e a 0,61 no período de 1980 a 2002.

As exportações brasileiras de café para a França aumentaram de 1961 a 2002, mas o Brasil praticamente manteve seu market share nesse mercado. Em 1961, o Brasil respondeu por 15,9\% das importações globais de café da França e em 2001, por 17,5\%. O produto brasileiro na França tem se caracterizado como um bem inferior, ou seja, com elasticidade-renda negativa. No período de 1962 a 2002, a elasticidade-renda da demanda 
francesa por café brasileiro foi de $-0,15$, passando a $-0,69$ no período de 1970 a 2002 e a 1,50 no período de 1980 a 2002. Portanto, a França, assim como os EUA, não é um mercado promissor para as exportações brasileiras de café verde, devendo os produtores brasileiros procurarem um novo produto a ser exportado para o mercado francês.

O Japão aumentou expressivamente as importações de café brasileiro no período de 1961 a 2000 , absorvendo, em 2001, cerca de 7,5\% das exportações brasileiras desse produto. Ao mesmo tempo, o Brasil ampliou o seu market share no mercado japonês, respondendo por $15,8 \%$ das importações japonesas de café em 1961 e por $24,7 \%$ em 2001. No Japão, o café brasileiro é um bem normal. No período de 1962 a 2002, a elasticidade-renda da demanda japonesa por café brasileiro foi de 1,01, passando a 0,91 no período de 1970 a 2002 e a 0,52 no período de 1980 a 2002.

O mercado doméstico é, atualmente, o segundo maior consumidor do produto brasileiro. De 1965 a 1986, a demanda doméstica per capita de café diminuiu, mas a mesma vem aumentando desde 1987. Ao mesmo tempo, o produto passou de bem inferior a bem normal para o consumidor brasileiro. No período de 1961 a 2002, a elasticidade-renda da demanda doméstica por café brasileiro foi de $-0,09$, passando a 0,16 no período de 1970 a 2002 e a 0,39 no período de 1980 a 2002 .

Os resultados acima indicam que na Alemanha, Itália, Japão e no mercado doméstico ainda é possível esperar novos aumentos da demanda de café verde na medida que essas economias cresçam.

De modo geral, em todos os períodos considerados no presente trabalho (de 1961 a 2002, de 1970 a 2002 e de 1980 a 2002) e para todos os mercados, o café é um produto de demanda inelástica a variações de preço e essa inelasticidade pouco tem se alterado ao longo do tempo. Assim, resultados que indicam diminuição da inelasticidade da demanda global por café exportado pelo Brasil (como os trabalhos de Almeida, 1993 e Alvim et al. 2003) se explicam pelo incremento das exportações brasileiras de café para novos mercados, não considerados no presente trabalho.

Como a demanda por café brasileiro nos principais países consumidores (explorado neste trabalho) não tem se tornado menos inelástica, é possível que novos mercados (não considerados neste trabalho), como a China, por exemplo, estejam apresentando demanda 
mais elástica pelo café brasileiro. Assim sendo, as considerações sobre elasticidades da demanda global por café são distintas das estimativas realizadas por mercado separadamente, onde se inserem as contribuições deste trabalho.

Há que se destacar que os novos mercados conquistados pelo café brasileiro ainda apresentam séries de dados anuais curtas, o que inviabiliza análises semelhantes às que foram realizadas para os mercados tradicionais neste trabalho.

De modo a complementar os estudos já existentes e enriquecer as discussões sobre este setor, sugerem-se, para trabalhos futuros, estudos exploratórios dos mercados emergentes e potenciais consumidores de café brasileiro, uma vez que pouco se conhece acerca do perfil da demanda destes mercados e sua importância tem aumentado sistematicamente.

A análise do problema da não estacionariedade das séries, bem como o teste de cointegração, não realizado no presente trabalho, também poderiam trazer maiores contribuições para a interpretação dos resultados das estimativas, por se tratar de uma alternativa eficiente para se lidar com as séries não estacionárias. 
ANEXOS 


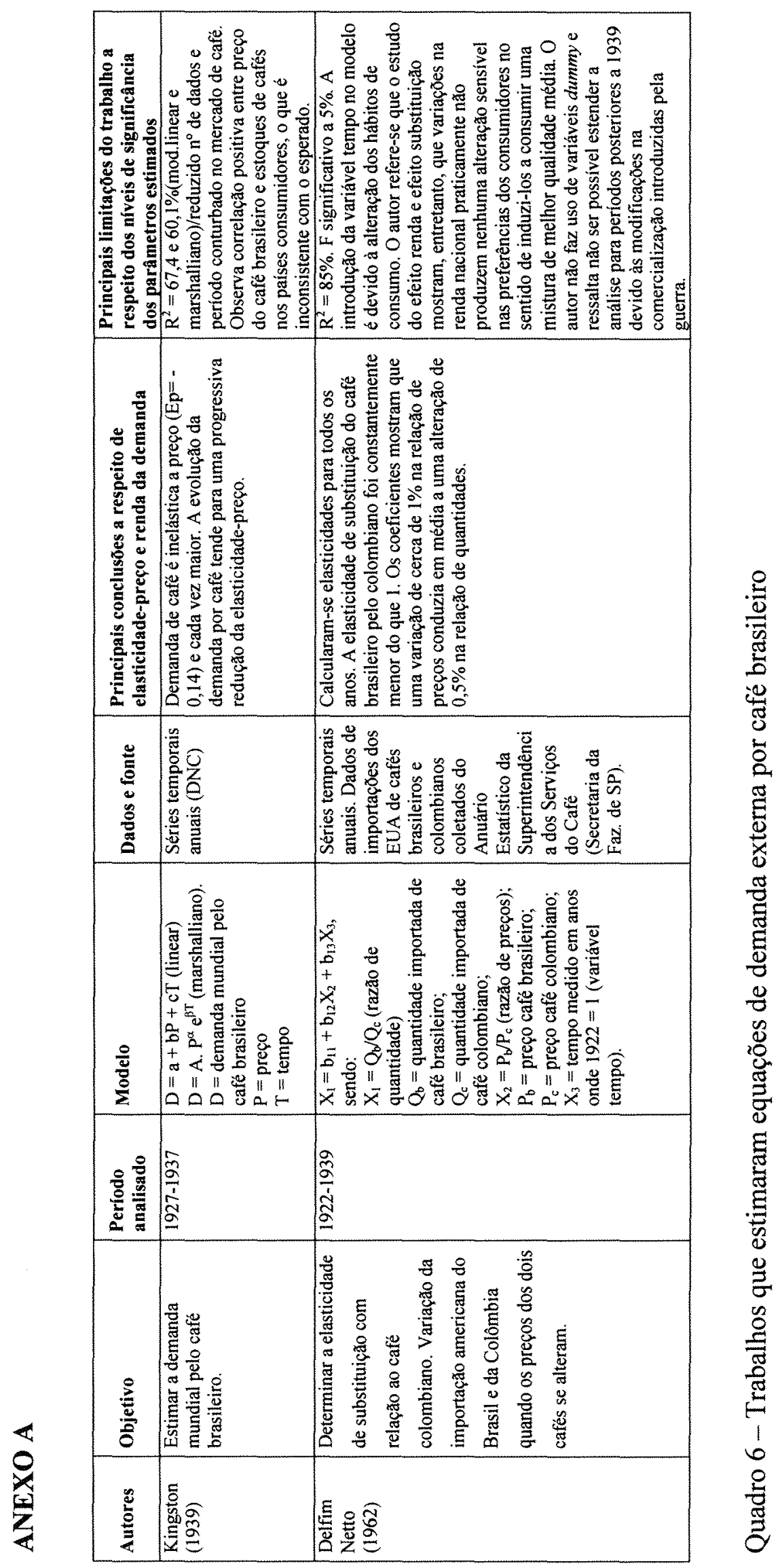




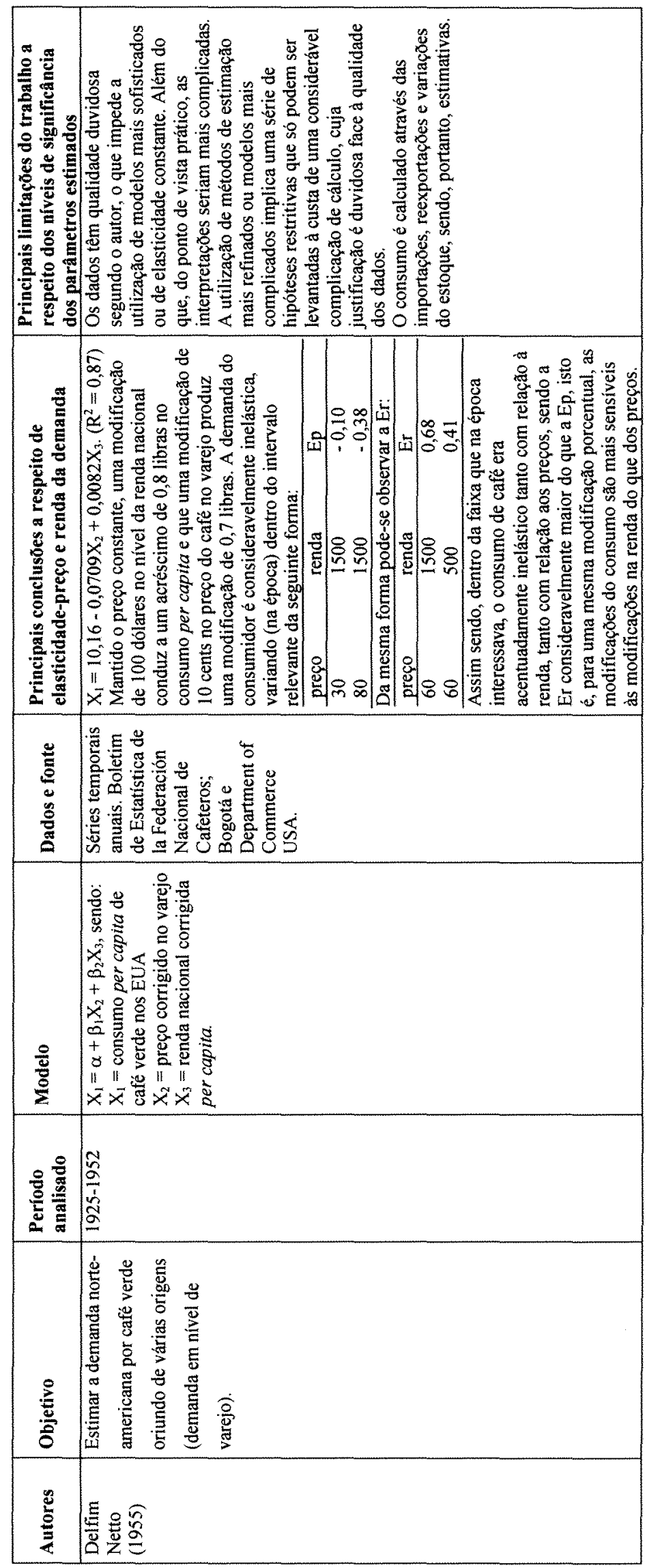

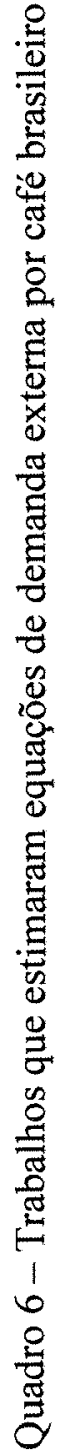




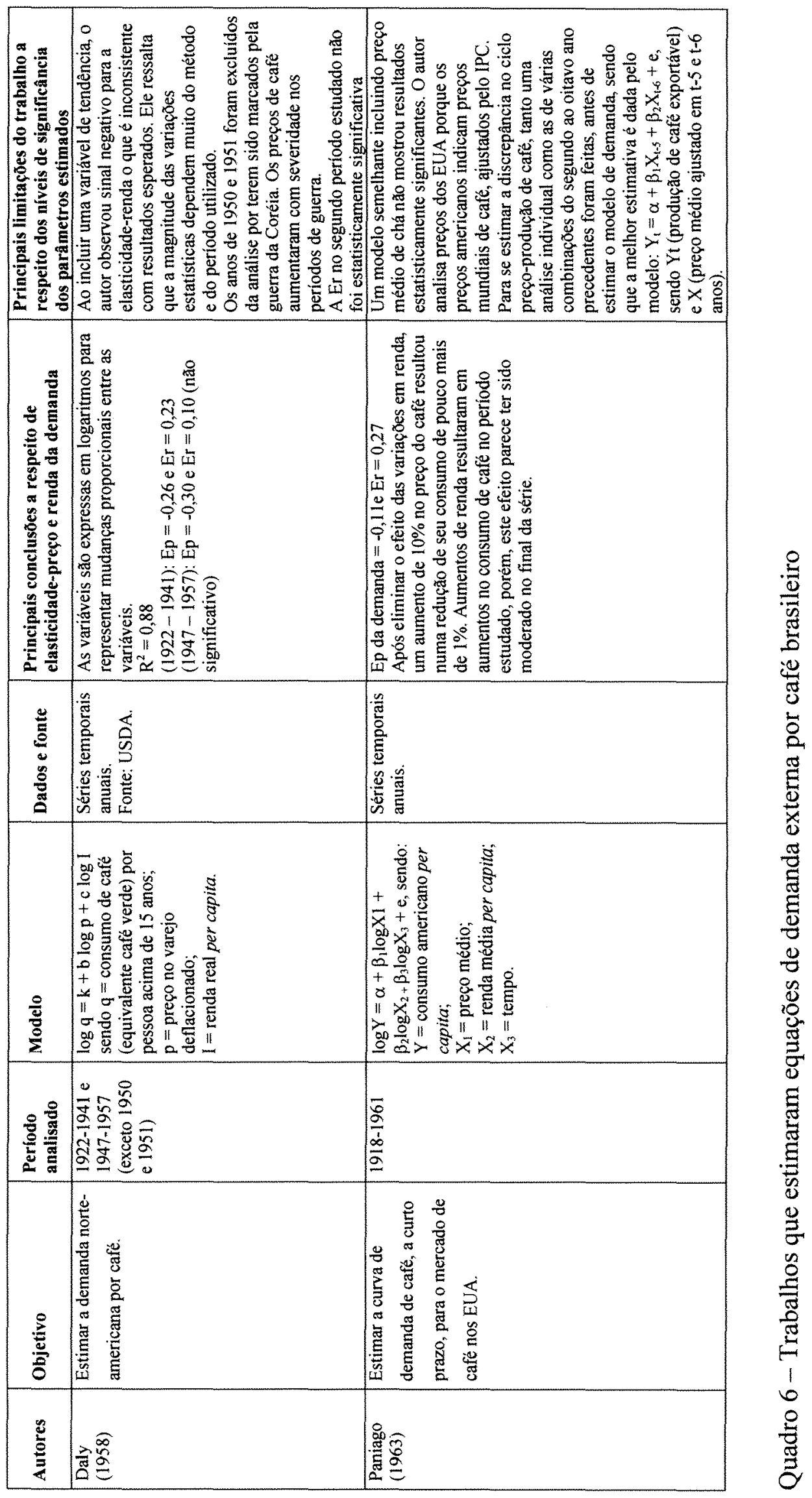




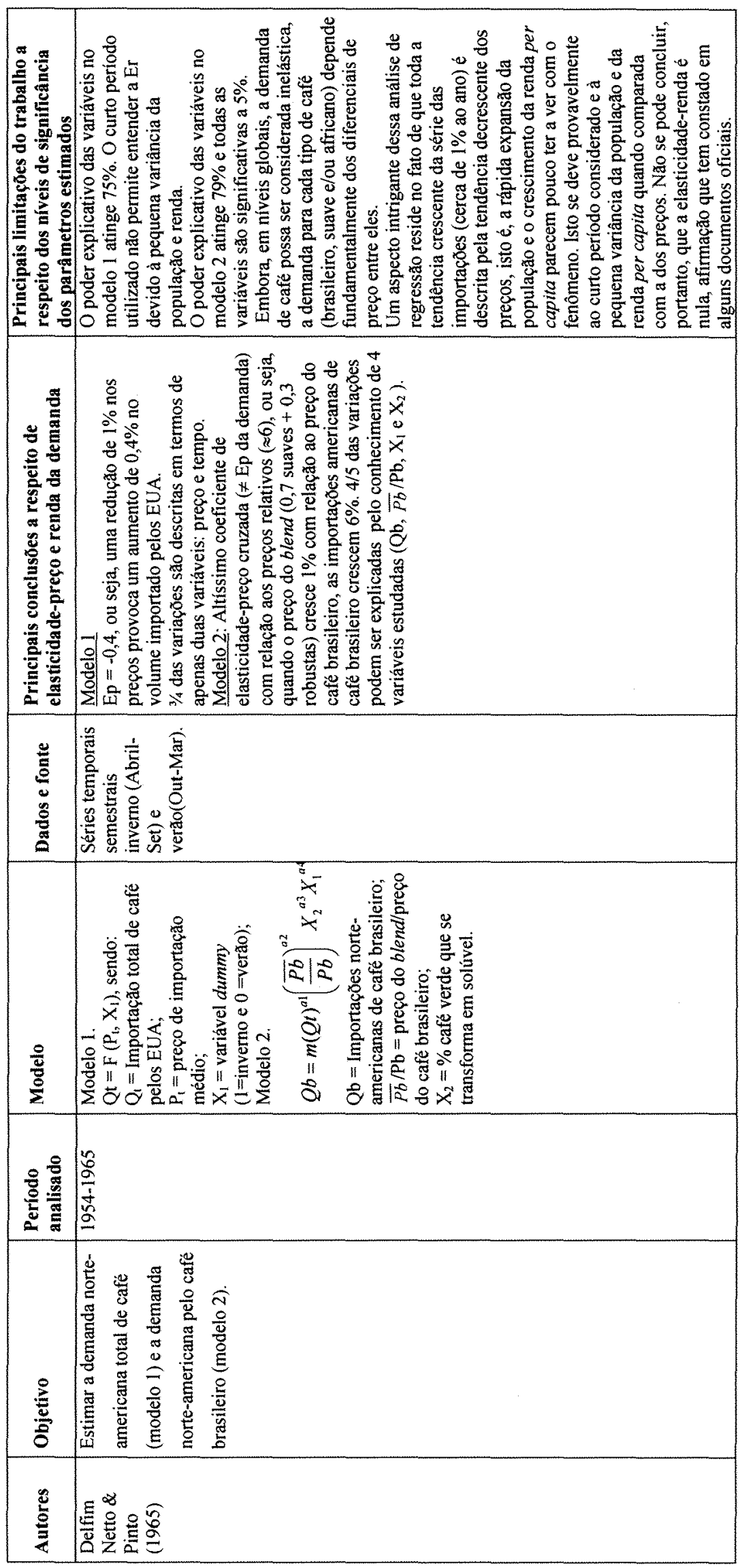




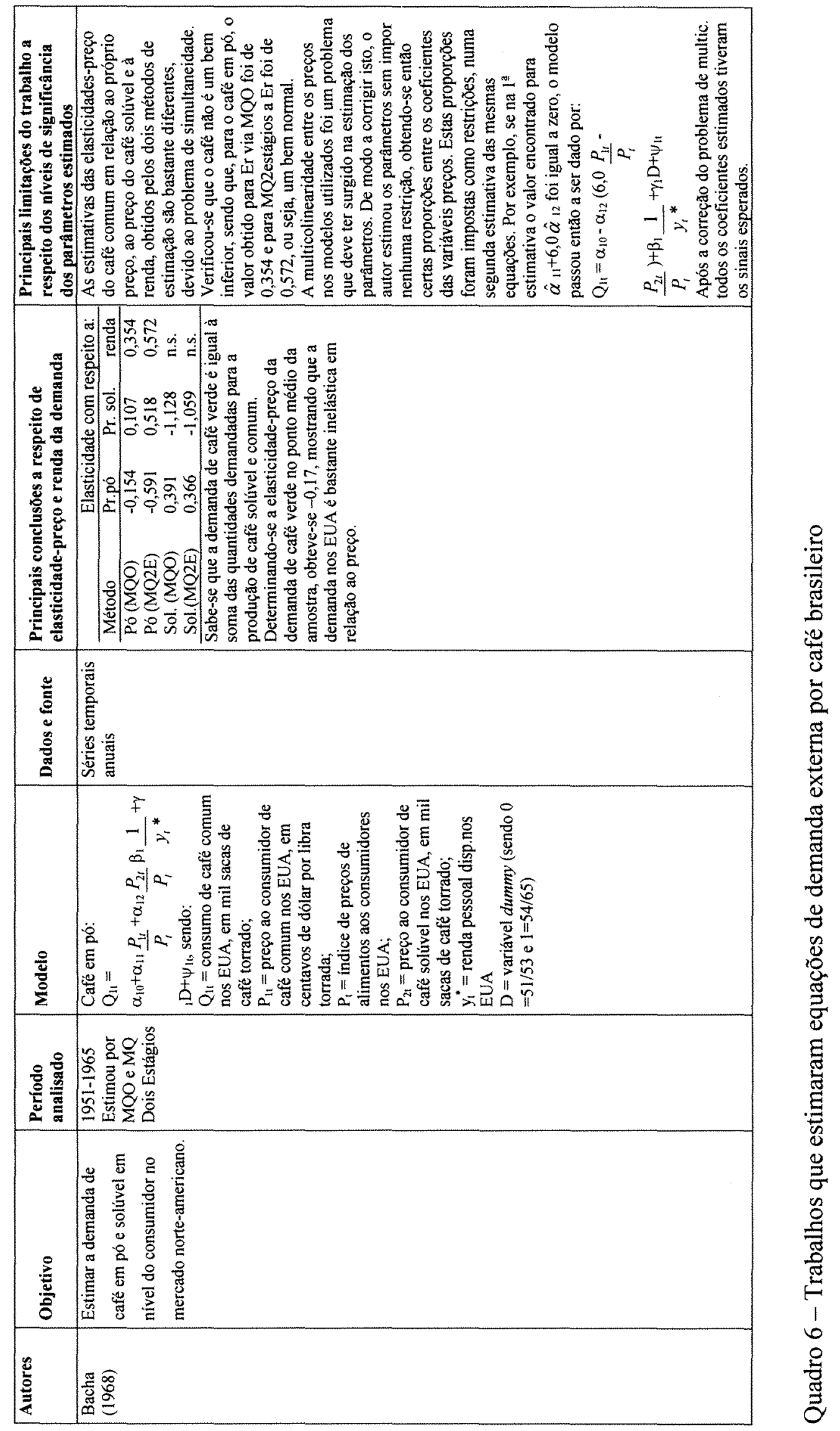




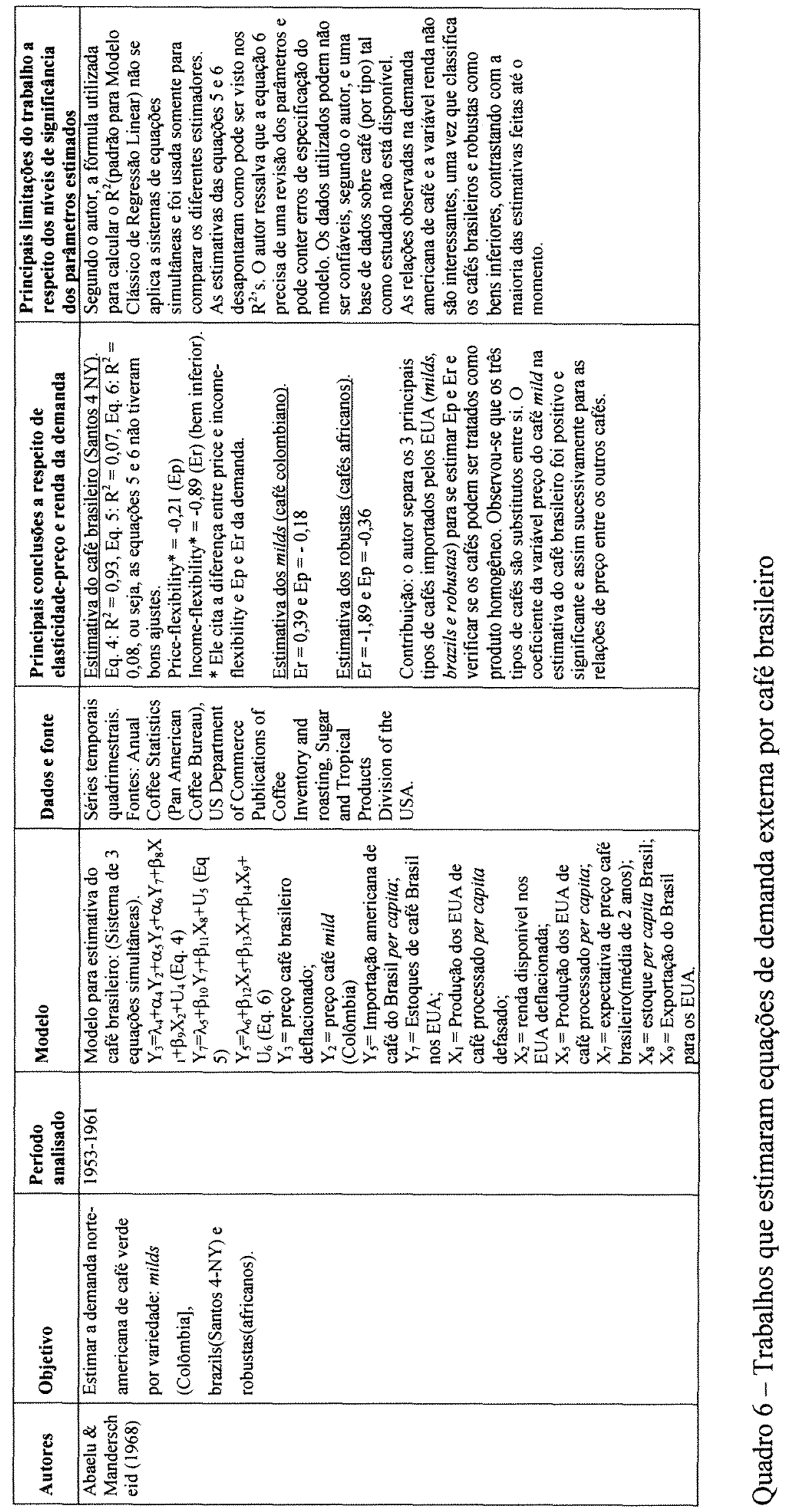




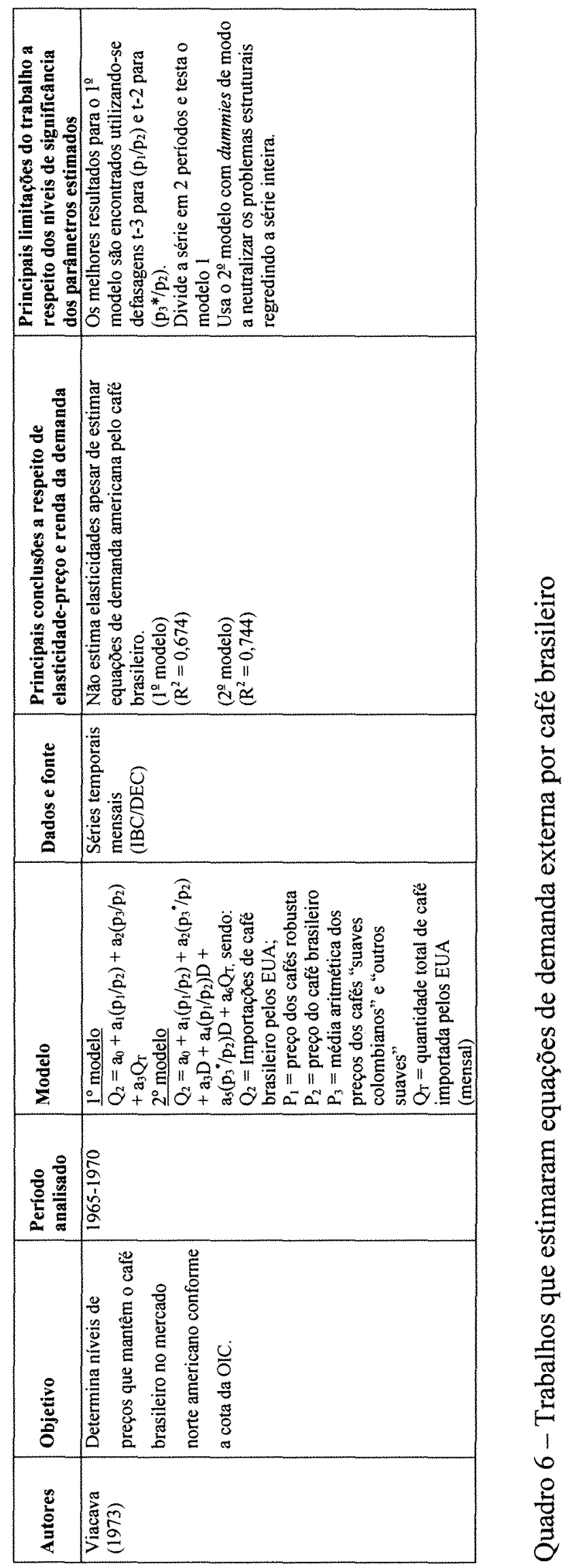




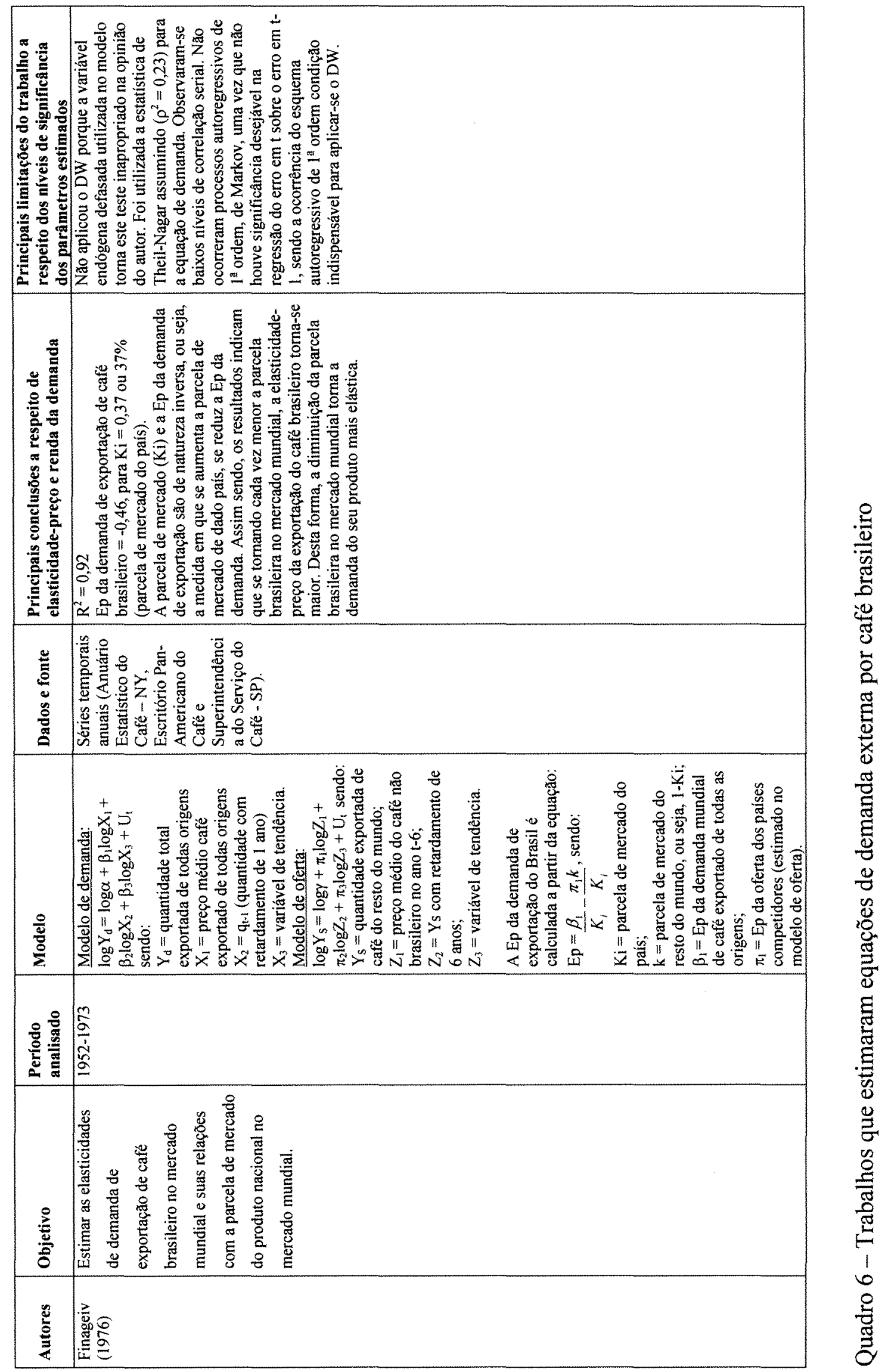




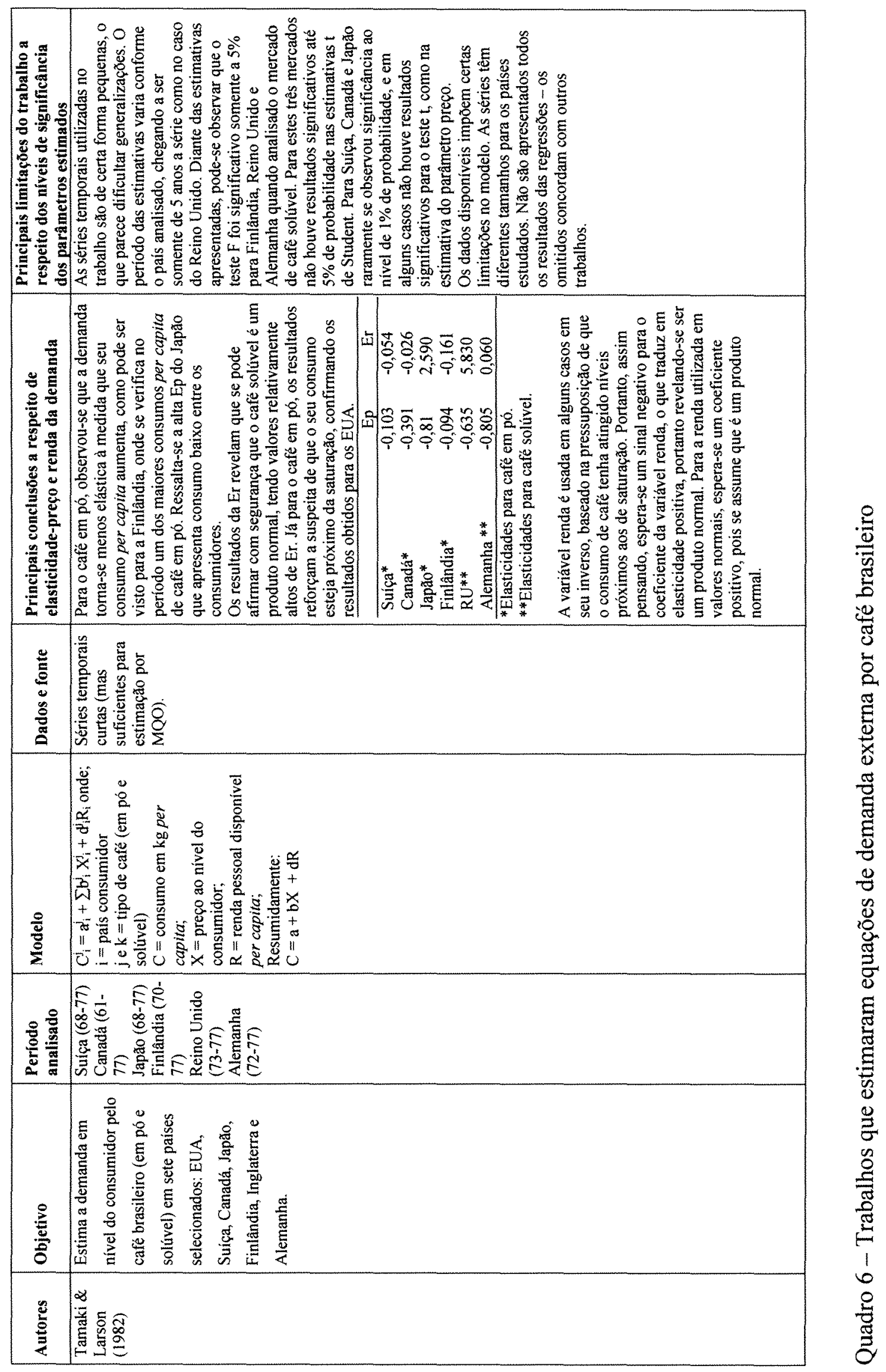




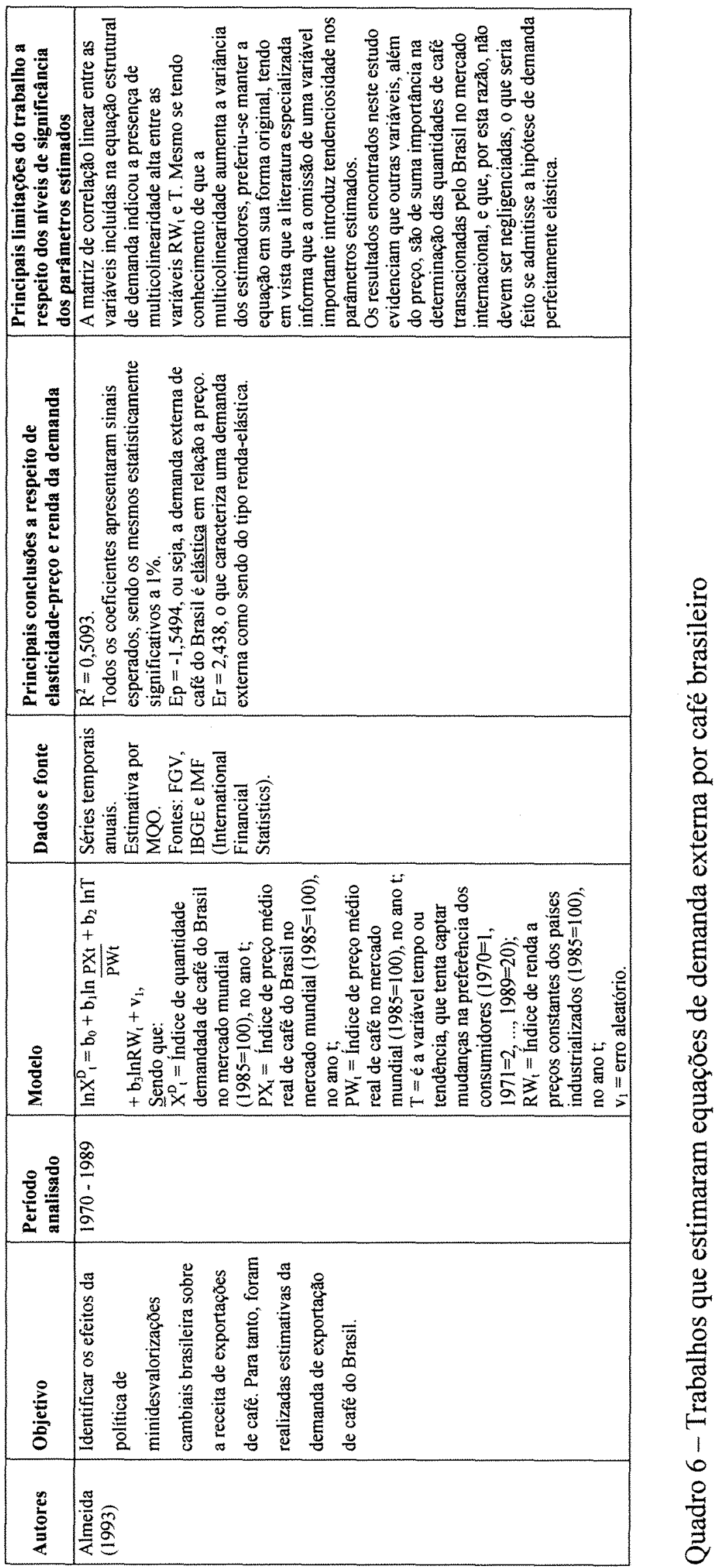




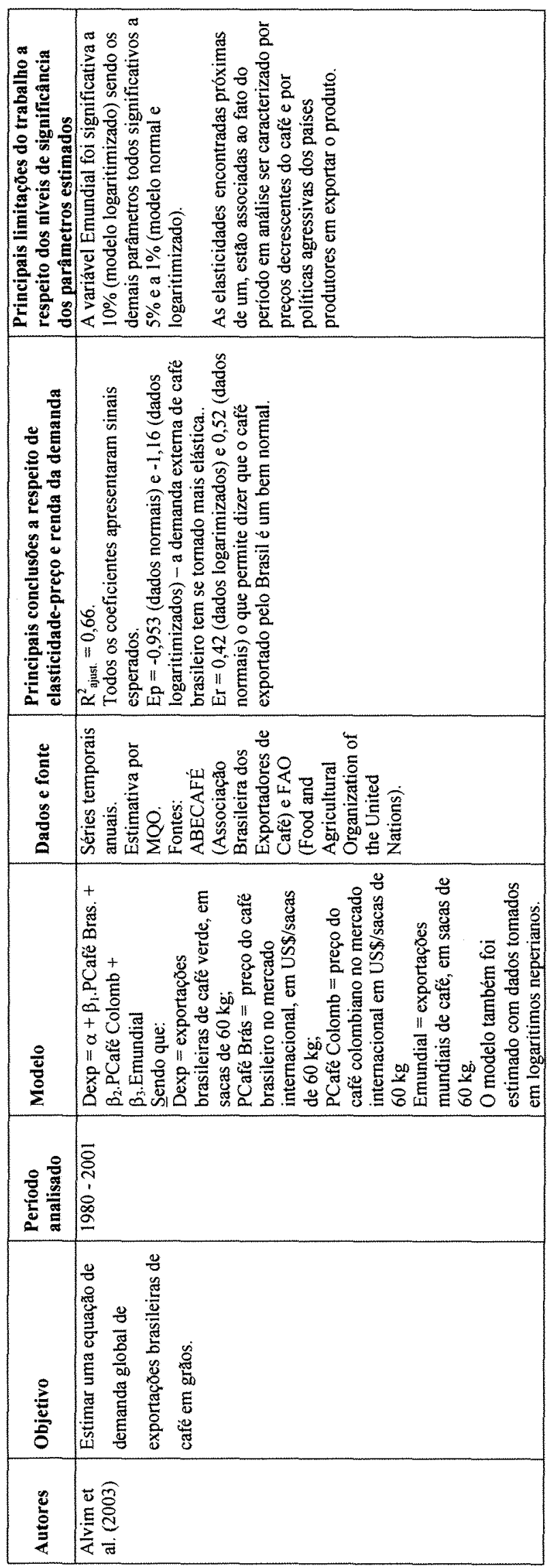




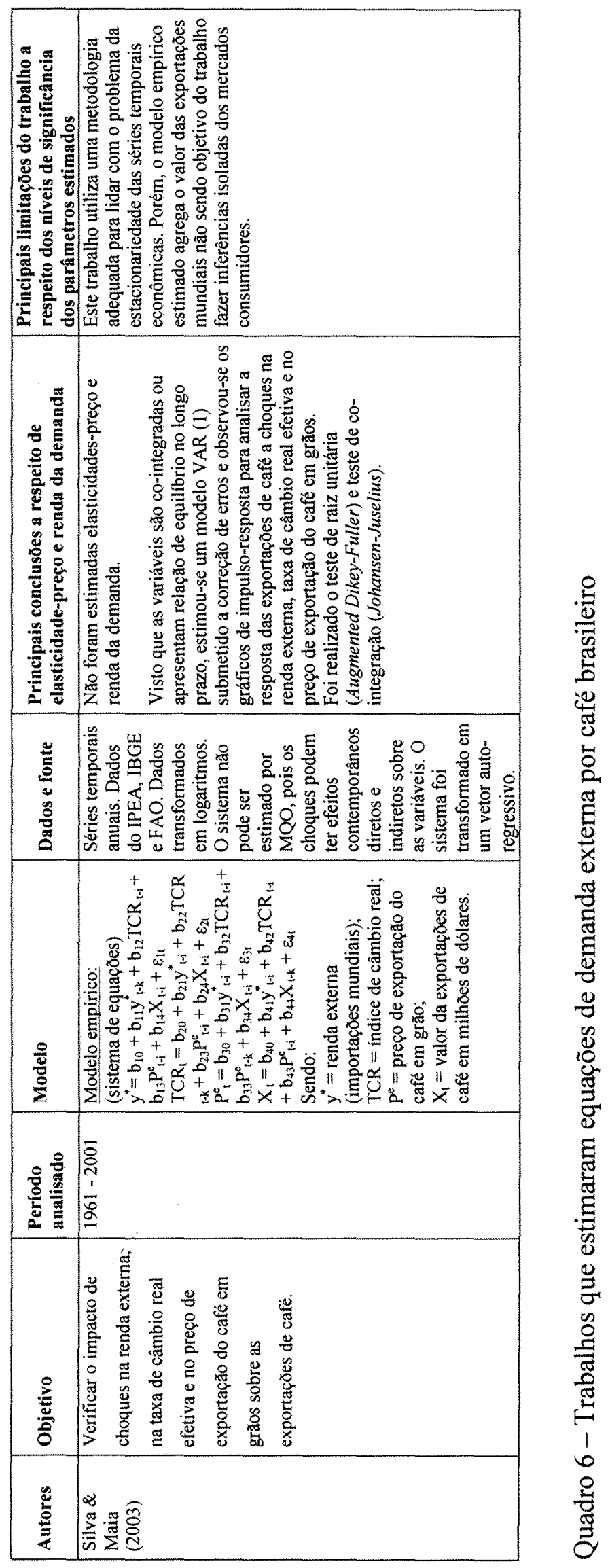




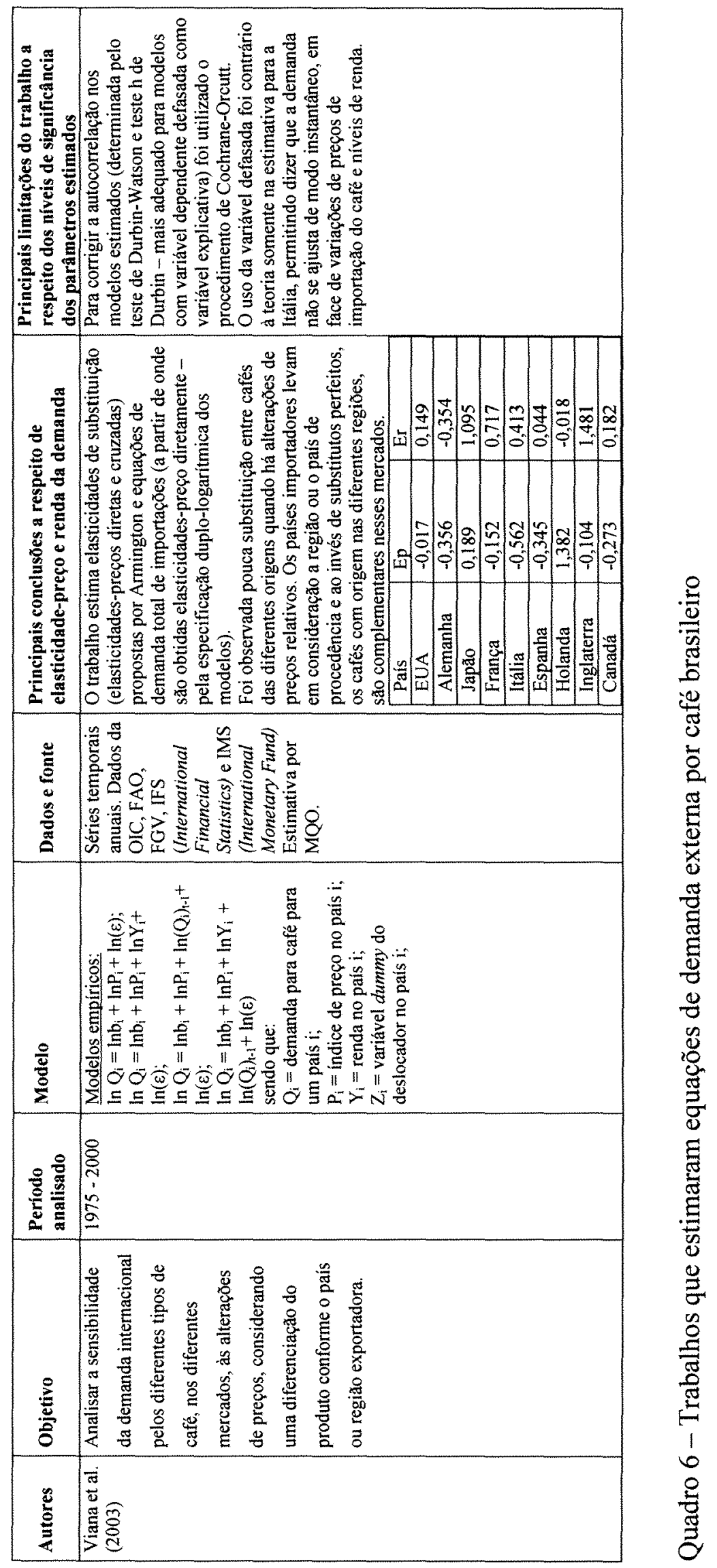




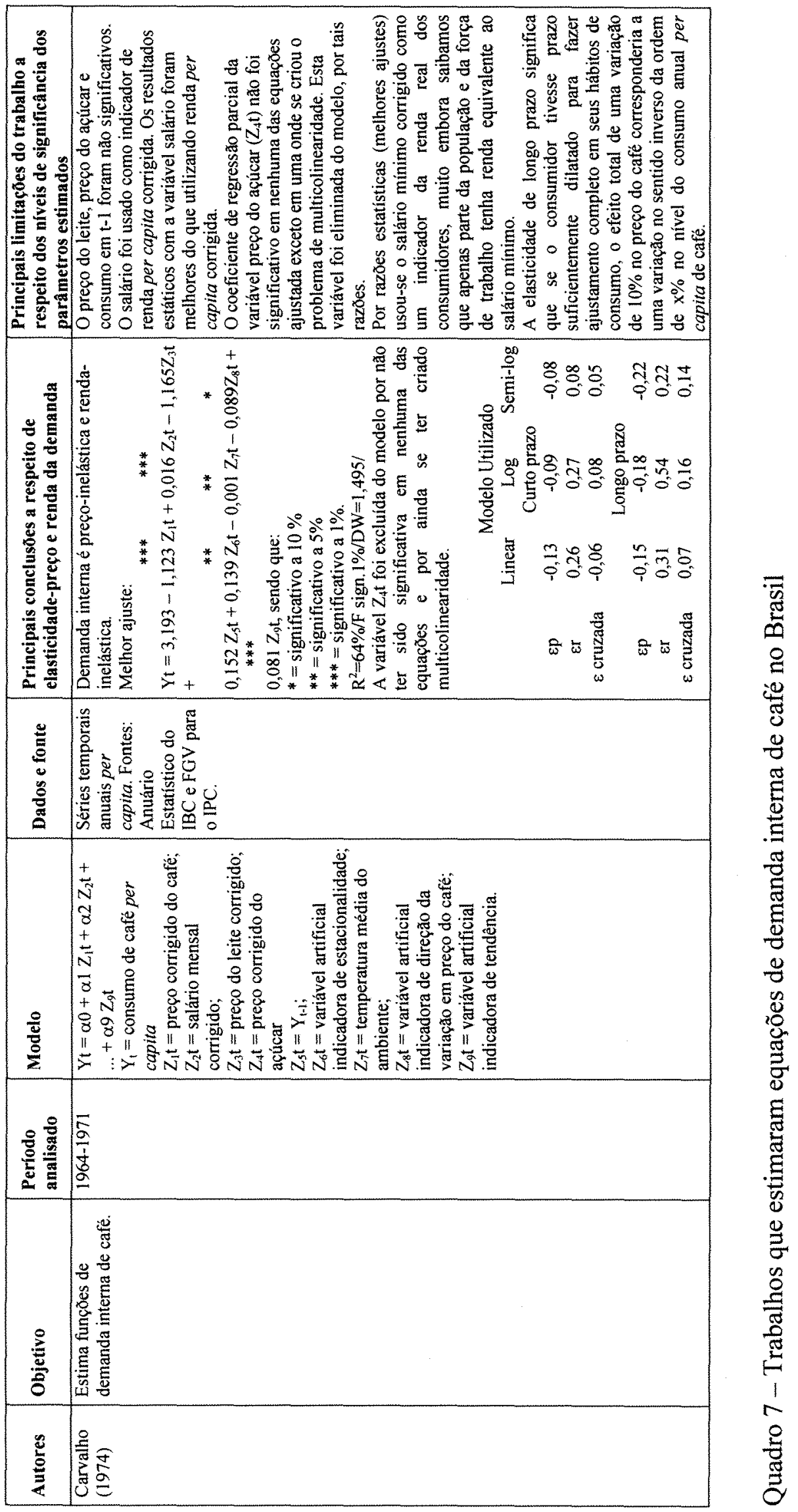




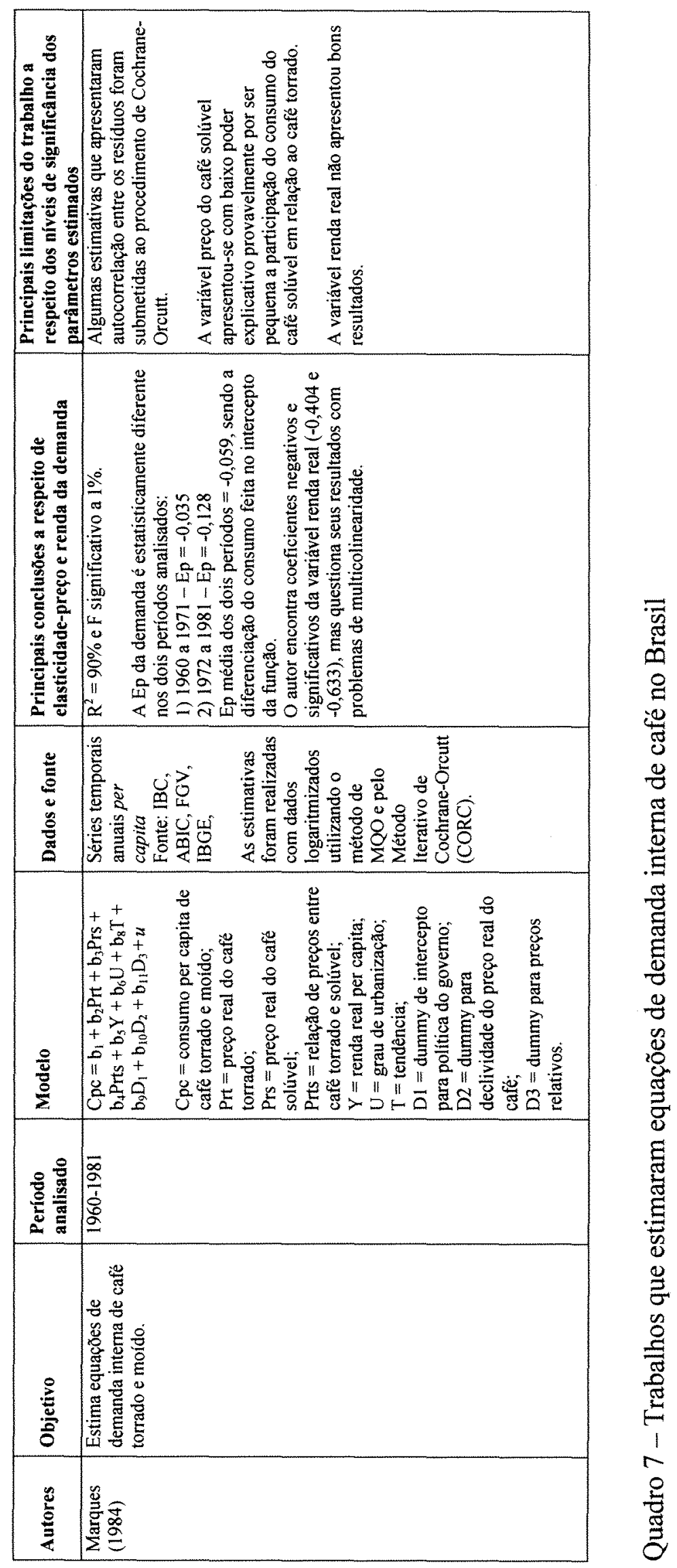




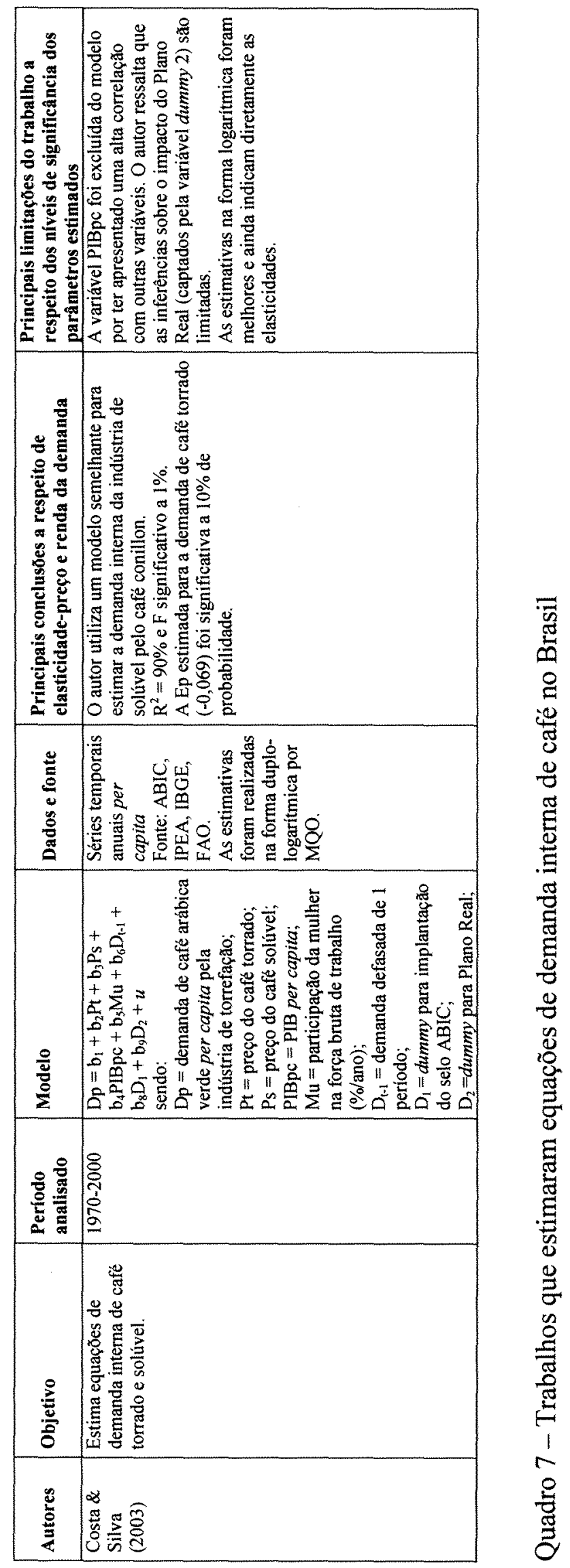




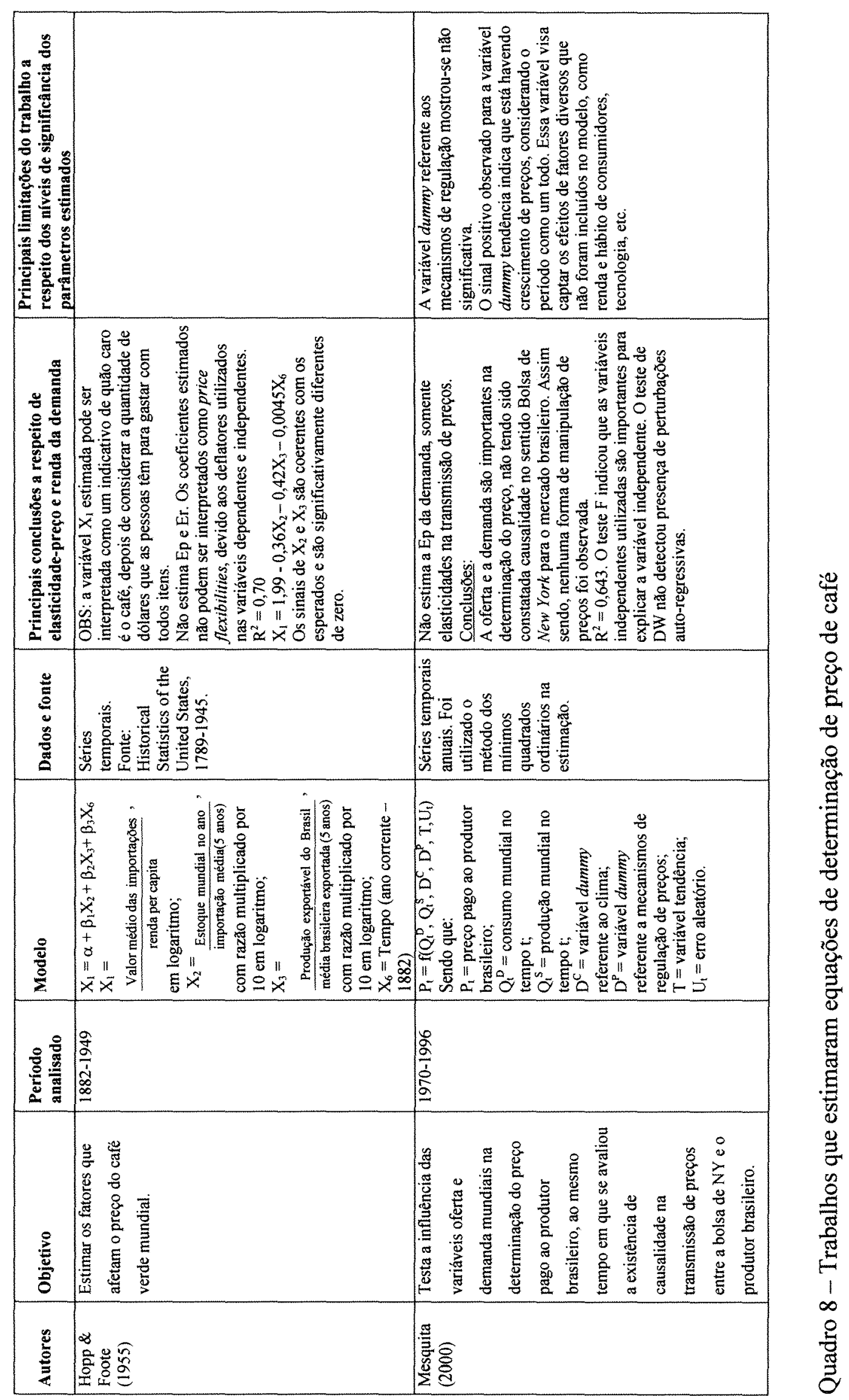




\section{ANEXO B}

As legendas descritas a seguir referem-se às abreviações das variáveis associadas aos dados apresentados nas tabelas 10 a 15 , a seguir:

$\mathrm{Y}=$ Importações de café verde do país i provenientes do Brasil (em sacas);

Ypc $=$ Importações de café verde do país i provenientes do Brasil, em termos per capita ( $\mathrm{kg}$ café verde/habitante/ano);

$\operatorname{Pr}=$ Preço do café verde brasileiro exportado para o país i (US\$/saca);

$\mathrm{Pib}=$ Índice real do PIB;

Pibpc = Índice real do PIB em termos per capita;

Pcs = Preço do café substituto ao café brasileiro no país i (US\$/saca);

Pio = Preço de importação de outras bebidas não alcoólicas pelo país i (US\$/kg);

Peo = Preço de exportação de outras bebidas não alcoólicas pelo país i (US $\$ / \mathrm{kg}$ );

Pic $=$ Preço de importação de chá pelo país i (US\$ $/ \mathrm{kg}$ );

Pec $=$ Preço de exportação de chá pelo país i (US\$/kg);

Pis = Preço de importação de suco de laranja pelo país i (US\$ $/ \mathrm{kg}$ );

Pes = Preço de exportação de suco de laranja pelo país i (US\$ $/ \mathrm{kg})$;

Mo $=$ Média aritmética dos preços de importação e exportação de outras bebidas não alcoólicas pelo país i (US\$/kg);

$\mathrm{Mc}=$ Média aritmética dos preços de importação e exportação de chá pelo país $\mathrm{i}$ (US\$/kg);

Ms = Média aritmética dos preços de importação e exportação de suco de laranja pelo país i (US\$ $/ \mathrm{kg})$;

$\mathrm{Cpc}=$ Consumo brasileiro de café verde em termos per capita;

$\operatorname{Pr}=$ Preço recebido pelo produtor paulista pela saca de café de $60 \mathrm{~kg}$ beneficiada (R\$ deflacionados pelo IGP-DI, agosto de $1994=100$ );

Pibpc $=$ PIB brasileiro em termos per capita;

Os valores de Pcs, Pio, Peo, Pic, Pec, Pis, Pes, Mo, Mc e Ms foram deflacionados pelo IPA - EUA (base $1995=100$ ), 
Tabela 10. Dados utilizados nas regressões da demanda dos EUA por café brasileiro

\begin{tabular}{|c|c|c|c|c|c|c|c|c|c|c|c|c|c|c|c|}
\hline Ano & $Y$ & Ypc & or & IB & $B p c$ & s & 10 & eo & 10 & ic & $e$ & ac & Pis & Pes & Us \\
\hline & & 2,73 & 9,36 & 87 & & & 0,33 & 23 & 28 & 10 & 4,97 & 3,03 & 00 & 78 & 0,39 \\
\hline & & 2,55 & & & & & & & & & & 10 & 0 & 64 & \\
\hline 1963 & 17.000 & 2,72 & 153,53 & 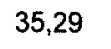 & 92 & & 0,30 & 22 & 0,26 & 1,02 & 7,24 & 4,13 & 44 & 90 & 67 \\
\hline & 0 & 1,93 & 208,10 & & & & 31 & & 27 & 99 & & & 67 & 94 & \\
\hline & & 1,81 & & & & & . & & & & & 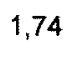 & 10 & . & \\
\hline 100 & & 2,01 & & & & & 0,29 & & & 95 & 1,72 & 1,33 & 21 & 75 & \\
\hline 1967 & 56 & 1,92 & 69 & 3,39 & 36 & & 0,00 & 0,26 & 13 & 0,90 & 2,55 & 1,72 & 28 & 60 & \\
\hline 10 & & 2,32 & & & & & & & & & & & 8 & 99 & \\
\hline & & 1,74 & & & & & & & & 83 & 2,73 & 1,78 & 38 & 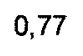 & \\
\hline $197 C$ & & 1,41 & 35 & 6 & 6 & & 0,00 & & 2 & 0,84 & 2,08 & 1,46 & 58 & 63 & 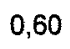 \\
\hline 1971 & & 1,65 & 145,22 & 48 & & & 0,00 & 24 & 2 & 90 & 2,90 & 1,90 & 32 & 71 & \\
\hline 197 & & 1,69 & & & & & & & & & & & & & \\
\hline 197 & & 1,34 & 186,41 & 4,05 & & & 0,00 & & & 3 & 3,40 & 2, & & 14 & \\
\hline 19 & & 0,75 & 81 & 8 & & & 0,00 & & 3 & 8 & 2,31 & 1,64 & 37 & 8 & \\
\hline 197 & 663 & 0,94 & 123,37 & 3,68 & 65,82 & 76 & 0,00 & 41 & 21 & 1,22 & 2,45 & 1,83 & 30 & 84 & c \\
\hline 197 & & 0,96 & 339,78 & & 68,65 & & 0,00 & & & 6 & 3 & & & 82 & \\
\hline 197 & 7 & 0,46 & 516,29 & & 12 & & 0,00 & & 4 & & 3 & 2 & & 01 & \\
\hline 19 & & 0,75 & 2,86 & 2,44 & 74,32 & 3,17 & 0,00 & &, 27 & 1,66 & 3,79 & 2,7 &, 00 & 82 & \\
\hline $197 !$ & 33 & 0,53 & 332,28 & 4,41 & 75,90 & 30 & 0,00 & 4 & 07 & 1,58 & 4,05 & 2,8 & 62 & 2 & \\
\hline 198 & & 0,88 & & & & & 0 & 0 & & 5 & 4,38 & 2, & & 6 & \\
\hline 19 & & 0,76 & 30 & & 76 & & 0 & & 06 & 4 & 5 & 3 & & 3 & \\
\hline 198 & & 0,90 & 1,59 & 64,61 & 73,84 & 203,34 & 0, & 0, & 25 & 1,55 & 5,50 & 3,5 & 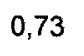 & 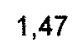 & 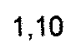 \\
\hline 198 & & 0,85 & 177,85 & 67,5 & 76,39 & 26 & 0,63 & 0.5 & 57 & 1,91 & 5,63 & 3,77 & 78 & 34 & 06 \\
\hline & & 0,97 & & & & & 0,67 & & & 32 & 6,31 & 4,41 & 5 & 57 & 1,31 \\
\hline & & 1,09 & & & & & & & & & 6 & & & 9 & \\
\hline 10 & & 0 & 287 & & & & & & & 8 & 5 & 3 & & 8 & \\
\hline 198 & & 0,99 & 139,18 & 80 & 87,66 & 5 & 0,72 & 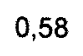 & 5 & 1,58 & 5,63 & 3,60 & 33 & 33 & 08 \\
\hline & & 0,95 & 150 & 8 & & & 0,74 & & & 63 & 6,10 & 3,86 & 28 & 1,59 & 1,44 \\
\hline 198 & & 0,90 & 104,91 & 86,9 & & & 0,81 & & & 1,68 & 5,27 & 3,48 & 5 & 8 & 1,31 \\
\hline 199 & & 0,96 & & 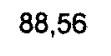 & & & & & & 1,84 & 4,91 & 3,37 & & 6 & 1,37 \\
\hline 199 & & 1,11 & 64,25 & 184 & 92,36 & 119,83 & 0,86 & $0 ?$ & 32 & 1,65 & 4,96 & 3,30 & 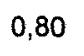 & 43 & \\
\hline 199 & & 0,85 & 63,87 & & & & 83 & 0,35 & 59 & 1,60 & 4,50 & 3,05 & 0,82 & 1,43 & 1,13 \\
\hline 199 & 806 & 0,78 & 62,95 & 93,7 & 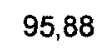 & 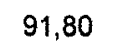 & 36 & & & 1,63 & 4,30 & 2,96 & 0,72 & 0 & 1,11 \\
\hline 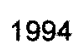 & & 0 & & & & & 0,81 & & & 1,58 & 5,17 & 3,37 & 0,72 & 19 & 1,46 \\
\hline 199 & 2.056 .132 & 0,46 & 0,00 & 0000 & 100,00 & 212,86 & 0,76 & 0,3 & 55 & 1,61 & 4,68 & 3,14 & 0,83 & ,25 & 1,54 \\
\hline 1996 & 876 & 0,44 & 58,63 & 103,70 & 102,57 & 150,49 & 0,75 & 39 & 57 & 1,63 & 4,62 & 3,12 & 0,95 &, 13 & 1,54 \\
\hline 199 & 2.228 .056 & 0,48 & 58,66 & 108 & 106,01 & 207,60 & 0,70 & 0 & 66 & 1,82 & 3,66 & 2,74 & 0,78 & 1,83 & 1,31 \\
\hline 19 & & 0,6 & & 10 & $10 s$ & & 0,69 & & 7 & 1,88 & 3,56 & 2,7 & 0,85 & 1,89 & 1,37 \\
\hline 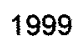 & 4.696 .196 & 1,00 & 59,66 & 117,91 & & & 0,14 & 0,40 & & 1,78 & 3,44 & 2,61 & , 19 &, 94 & 1, כ, \\
\hline 2000 & 2.297 .820 & 0,48 & 56,40 & 122,23 & 115,77 & 112,29 & 0,76 & 0,44 & 0,60 & 1,83 & 4,08 & 2,96 & 0,73 & 1,91 & 1,32 \\
\hline 200 & 2.796 .650 & 0,58 & 55,78 & 122,85 & 115,14 & 72,38 & 0,78 & 0,50 & 0,64 & 1,79 & 3,97 & 2,88 & 0,69 & 1,95 & 1,32 \\
\hline 2002 & 4.951 .463 & 1,02 & 57,09 & 125,54 & 116,44 & 70,70 & 0,72 & 0,54 & 0,63 & 0,00 & 4,16 & 2,08 & 0,00 & 1,62 & 0,81 \\
\hline
\end{tabular}

Fontes: Brasil (2003), IPEA (2003) e FAO (2003) 
Tabela 11. Dados utilizados nas regressões da demanda da Alemanha por café brasileiro

\begin{tabular}{|c|c|c|c|c|c|c|c|c|c|c|c|c|c|c|c|}
\hline A & $Y$ & $c$ & r & B & $c$ & $s$ & 0 & 0 & 0 & c & $c$ & c & is & es & is \\
\hline 1961 & 36.000 & 0,60 & 74,36 & 34,81 & 8,71 & 38,73 & 0,09 &, 06 &, 08 & 25 & 1,72 & , 48 &, 00 &, 00 & 0,00 \\
\hline 1962 & 99.000 & 0,65 & & 36,45 & & & 0,24 & 18 & 21 & 17 & 65 & 41 & 00 & 00 & 00 \\
\hline 1963 & 000 & 95 & 8,32 & 37,52 & & 7,31 & 0,18 & 23 & 21 & 90 & 61 & 25 & 00 & 00 & 00 \\
\hline 34 & 0 & 0,66 & 88 & 39,94 & & 52 & 0,18 & 23 & 21 & 89 & 1,60 & 25 & .00 & .00 & 00 \\
\hline 1965 & 00 & 0,77 & 27 & & & & 0,22 & 28 & & 89 & .71 & 30 & 00 & 00 & כo \\
\hline 1 & & 0,74 & 69 & & & & 0,22 & 29 & & 87 & 1,74 & 30 & 81 & 61 & 21 \\
\hline & 8.429 & 72 & & 43 & & & 0,21 & 27 & & 89 & 1,83 & 36 & 67 & 00 & 84 \\
\hline & 23 & 84 & & & & & 0,19 & & & 1 & 1,72 & 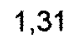 & 80 & 9 & 04 \\
\hline & & 88 & & & & & 0,22 & & & & 1,79 & & 0,79 & - & \\
\hline & & 79 & & & & & 0,23 & & & & 19 & 20 & 0,46 & . & \\
\hline & & 0,81 & & & & & 0,2 & & & & & & 43 & . & \\
\hline & & 0,99 & & & & & 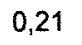 & & & & 2,47 & & 71 & 10 & 40 \\
\hline (1) & 70 & 1,08 & & ני & & & 0,22 & , & & 7 & 2,48 & 63 & 0,65 & S & \\
\hline 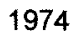 & 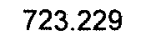 & 0,55 & 42 & 58 & 0 & 2 & 2 & 0,41 & 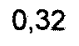 & 7 & 2,38 &, 58 & 0,77 & 1,22 & 99 \\
\hline 1 & 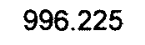 & 0,76 & 77 & 57 & 4 & 90 & 6 & 0 & & 1 & 2,77 & 1,79 & 0,70 &, 48 & 59 \\
\hline 1 & 04 & 01 & 49 & 60 & 8 & 66 & 0,27 & 0,42 & 4 & 2 & 2,68 & 1,75 & 0,55 & 27 &, 41 \\
\hline 1977 & 3 & 0,72 & 47 & 61,90 & 31 & 56 & 0,34 & 0,56 & 5 & 0 & 3,65 & 2,22 & 0,72 &, 35 & 3 \\
\hline 1978 & 76 & 0,74 & & 63 & 6 & 97 & 0,43 & 0,58 & 0 & 0,87 & 4,40 & 2,63 & 1,07 & 38 & 3 \\
\hline 1975 & 992 & 0,80 & 296,08 & 66,51 & 69,25 & 72 & 0,47 & 0,57 & 2 & 0,92 & 4,04 & 2,48 & 1,03 &, 40 & 2 \\
\hline 198 & 42 & 1,06 & 06 & 67,16 & & & 0,52 & 0,60 & 66 & 3 & 4,54 & 2,73 & 1,01 & 38 & 99 \\
\hline 1981 & 684 & 10 & 127,51 & 67,25 & 30 & 227,82 & 0,45 & 0,53 & 0,49 & 0,92 & 3,67 & 2,29 & 0,65 & 30 &, 48 \\
\hline 1982 & 380 & 1,65 & 16 & 66,55 & 69,75 & 242,74 & 0,42 & 0,53 & 0,48 & 0,90 & 3,50 & 2,20 & 1,11 & 0,29 & 10 \\
\hline 198 & 28 & 44 & 10 & 67,71 & 12 & 91 & 0,39 & 0 & 0,46 & 0,86 & 3,98 & 2,42 & 1,06 & 0,34 & 0 \\
\hline 198 & 88 & 17 &, 07 & 69,62 & 21 & 01 & 0,35 & 0,47 & 0,41 & 0,87 & 4,47 & 2,67 & 1,08 & 0,55 & 32 \\
\hline 198 & 59 & 116 & 16 & 71,21 & 74,85 & 228,91 & 0,32 & 0,44 & 0,38 & 0,87 & 5,57 & 3,22 & 1,33 &, 56 & 95 \\
\hline 198 & & & & & 76,42 & 311,75 & 0,43 & 0,56 & 0,50 & 0,88 & 5,47 & 3,17 & 1,03 & 0,67 & 0,85 \\
\hline & & & & & & & 0,47 & 0,68 & & 0,84 & 5,98 & 3,41 & 1,54 & 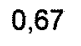 & \\
\hline & & & & & & & & 0,72 & 0,60 & 0,84 & 6,02 & 3,43 & 1,94 & 0,81 & \\
\hline 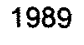 & & 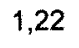 & & & & & & 0,66 & 0,60 & & 5,28 & 3,10 & 1,50 & 0,95 & \\
\hline 1990 & & 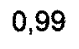 & & & & & & & & & 5,66 & 3,30 & 1,57 & & \\
\hline 1991 & & & & & & & & & & & 5,88 & 3,40 & & & \\
\hline 1992 & & & & & & & & & & & 6,16 & 3,55 & & & \\
\hline 1993 & & & & & & & & & & & 4,86 & & & 87 & 0,84 \\
\hline 1994 & 1.433 .483 & 1,06 & & 80,00 & & & & & & & 71 & & 1,27 & 0,54 & 0,90 \\
\hline 1995 & & 0,59 & & 100,00 & & & & 5 & 4 & & 3 & 00 & 1,45 & 0,62 & 1,04 \\
\hline 1996 & 1.626 .978 & 1,19 & & 100,76 & & & 0 & & 5 & 0 & 4,93 & 97 & 1,50 &, 06 & 1,28 \\
\hline 1997 & 2.705 .382 & 1,98 & 193,17 & 102,22 & &, 08 & 0,62 & 5 & 84 & 97 & 4,42 & 69 & 1,08 & 0,76 & 0,92 \\
\hline 1998 & 2.614 .529 & 1,91 & 142,03 & 104,07 & & 182,68 & 0,54 & 1 & 0,58 & 94 & 4,38 & 2,66 & 1,07 & 0,84 & 0,96 \\
\hline 1999 & 4.002 .813 & 2,92 & 110,79 & 106,30 & 105,58 & 129,58 & 0,50 & 0,52 & 0,51 & 0,98 & 4,58 & 2,78 & 1,50 & 1,18 & 1,34 \\
\hline 2000 & 2.693 .819 & 1,96 & 93,52 & 109,34 & 108,51 & 102,35 & 0,68 & 0,58 & 0,63 & 1,09 & 4,19 & 2,64 & 1,13 & 0,96 & 1,04 \\
\hline 2001 & 4.044 .205 & 2,95 & 54,96 & 110,27 & 109,35 & 73,42 & 0,44 & 0,47 & 0,46 & 0,97 & 4,18 & 2,58 & 0,85 & 1,02 & 0,93 \\
\hline 2002 & 5.397 .423 & 3,93 & 46,90 & 110,46 & 109,45 & 67,85 & 0,54 & 0,46 & 0,50 & 1,08 & 4,86 & 2,97 & 0,00 & 0,50 & 0,25 \\
\hline
\end{tabular}

Fontes: Brasil (2003), IPEA (2003) e FAO (2003) 
Tabela 12. Dados utilizados nas regressões da demanda da Itália por café brasileiro

\begin{tabular}{|c|c|c|c|c|c|c|c|c|c|c|c|c|c|c|c|}
\hline Ano & $Y$ & $Y p c$ & $\mathrm{Pr}$ & PIB & PIBpc & Pas & $\mathrm{Pio}$ & Peo & Mo & Pic & $\mathrm{Pec}$ & Mc & Pis & Pes & Ms \\
\hline 1961 & 60.000 & 1,02 & 156,10 & 30,81 & 34,92 & 139,39 & 0,33 & 0,25 & 0,29 & 1,40 & 6,00 & 3,70 & 0,57 & 0,62 & 0,60 \\
\hline 1962 & 30.000 & 0,69 & 139,10 & 32,71 & 79 & 2,21 & 0,29 & 26 & 28 & 31 & 2,50 & 1,91 & 0,38 & 0,66 & 52 \\
\hline 1963 & 1.268 .000 & 1,48 & 131,88 & 34,53 & 38,54 & 172,77 & 0,25 & 0,25 & 0,25 & 1,29 & 2,75 & 2,02 & 0,23 & 0,67 & 0,45 \\
\hline 1964 & 1.078 .000 & 1,25 & 161,41 & 35,44 & 39,25 & 182,29 & 0,19 & 0,27 & 0,23 & 1,31 & 4,75 & 3,03 & 0,33 & 0,67 & 0,50 \\
\hline 1965 & 568.000 & 0,65 & 191,53 & 36,56 & 40,20 & 181,80 & 0,26 & 0,29 & 0,27 & 1,30 & 3,25 & 2,28 & 0,29 & 0,70 & 0,49 \\
\hline 1966 & 1.391 .507 & 1,59 & 140,55 & 41,52 & 45,34 & 246,43 & 0,25 & 0,31 & 0,28 & 1,36 & 4,00 & 2,68 & 0,23 & 0,60 & 0,41 \\
\hline 1967 & 1.855 .901 & 2,11 & 128,06 & 44,50 & 48,28 & 300,17 & 0,20 & 0,32 & 0,26 & 1,41 & 2,75 & 2,08 & 0,43 & 0,57 & 0,50 \\
\hline 1968 & 1.511 .158 & 1,71 & 127,11 & 47,42 & 51,12 & 205,78 & 0,09 & 0,31 & 0,20 & 1,25 & 2,50 & 1,88 & 0,00 & 0,65 & 0,32 \\
\hline 1969 & 2.219 .602 & 2,49 & 133,07 & 50,31 & 53,90 & 284,88 & 0,14 & 0,28 & 0,21 & 1,31 & 1,92 & 1,62 & 0,35 & 0,42 & 0,38 \\
\hline 1970 & 2.245 .983 & 2,50 & 137,73 & 52,98 & 56,40 & 328,05 & 0,19 & 0,30 & 0,24 & 1,25 & 2,24 & 1,74 & 0,21 & 0,15 & 0,18 \\
\hline 1971 & 2.646 .847 & 2,93 & 135,27 & 53,98 & 57,11 & 418,33 & 0,25 & 0,32 & 0,28 & 1,44 & 2,86 & 2,15 & 0,43 & 0,59 & 0,51 \\
\hline 1972 & 2.446 .751 & 2,69 & 157,37 & 55,56 & 58,41 & 245,17 & 0,32 & 0,35 & 0,33 & 1,59 & 2,61 & 2,10 & 0,61 & 0,74 & 0,68 \\
\hline 1973 & 2.083 .899 & 2,28 & 173,41 & 59,20 & 61,86 & 202,51 & 0,44 & 0,39 & 0,41 & 1,49 & 2,73 & 2,11 & 0,33 & 0,24 & 0,29 \\
\hline 1974 & 1.299 .661 & 1,41 & 174,79 & 61,97 & 64,38 & 188,56 & 0,45 & 0,45 & 0,45 & 1,66 & 2,03 & 1,84 & 0,44 & 1,11 & 0,77 \\
\hline 1975 & 1.4 & 1,55 & 138,41 & 60,64 & 62,67 & 202,27 & 0,50 & 0,50 & 0,50 & 1,98 & 76 & 2,87 & 0,41 & 0,96 & 0,69 \\
\hline 1976 & 1.094 .335 & 1,18 & 327,06 & 64,59 & 66,44 & 195,61 & 0,41 & 0,43 & 0,42 & 1,88 & 3,32 & 2,60 & 0,86 & 1,11 & 0,98 \\
\hline 1977 & 1.185 .653 & 1,27 & 508,30 & 66,45 & 68,07 & 436,03 & 0,41 & 0,47 & 0,44 & 3,13 & 4,79 & 3,96 & 0,71 & 0,89 & 0,80 \\
\hline 1978 & 987.987 & 1,06 & 342,21 & 68,93 & 70,35 & 392,14 & 0,53 & 0,60 & 0,57 & 3,56 & 5,23 & 4,40 & 1,30 & 1,26 & 1,2 \\
\hline 1979 & 968.305 & 1,03 & 325,65 & 72,84 & 74,12 & 340,99 & 0,61 & 0,63 & 0,62 & 3,75 & 5,41 & 4,58 & 0,48 & 1,31 & 0,89 \\
\hline 1980 & 1.500 .348 & 1,60 & 264,69 & 75,41 & 76,57 & 346,99 & 0,62 & 0,75 & 0,69 & 3,91 & 5,96 & 4,93 & 0,51 & 1,21 & 0,86 \\
\hline 1981 & 1.339 .673 & 1,42 & 144,50 & 75,77 & 76,82 & 238,86 & 0,56 & 0,65 & 0,60 & 3,35 & 4,52 & 3,94 & 1,55 & 1,35 & 1,45 \\
\hline 1982 & 1.416 .607 & 1,50 & 157,79 & 76,12 & 77,11 & 205,90 & 0,58 & 0,60 & 0,59 & 3,12 & 4,84 & 3,98 & 1,41 & 0,90 & 1,16 \\
\hline 1983 & 1.488 .241 & 1,58 & 167,32 & 77,06 & 78,04 & 210,59 & 0,47 & 0,63 & 0,55 & 2,90 & 4,18 & 3,54 & 1,44 & 0,94 & 1,19 \\
\hline 1984 & 1.781 .586 & 1,89 & 170,02 & 79,18 & 80,18 & 248,77 & 0,45 & 0,55 & 0,50 & 4,16 & 5,65 & 4,90 & 1,10 & 0,95 & 1,0 \\
\hline 1985 & 1.382 .334 & 1,47 & 173,50 & 81,54 & 82,56 & 227,03 & 0,46 & 0,59 & 0,53 & 3,92 & 5,23 & 4,58 & 2,21 & 1,21 & 1,71 \\
\hline 1986 & 795.347 & 0,84 & 314,37 & 83,60 & 84,64 & 276,78 & 0,73 & 0,80 & 0,77 & 4,09 & 5,36 & 4,73 & 1,12 & 0,89 & 1,01 \\
\hline 1987 & 1.381 .845 & 1,46 & 126,19 & 86,09 & 87,15 & 244,44 & 0,96 & 0,90 & 0,93 & 4,78 & 7,25 & 6,02 & 1,04 & 1,19 & 1,11 \\
\hline 1988 & 1.132 .233 & 1,20 & 159,44 & 89,49 & 90,56 & 191,72 & 1,01 & 0,84 & 0,92 & 4,83 & 7,14 & 5,99 & 0,97 & 1,57 & 1,27 \\
\hline 1989 & 1.369 .790 & 1,45 & 116,02 & 92,06 & 93,11 & 182,06 & 0,88 & 0,66 & 0,77 & 4,63 & 8,22 & 6,42 & 1,72 & $1,4 €$ & 1,59 \\
\hline 1990 & 1.160 .760 & 1,23 & 90,92 & 93,88 & 94,84 & 118,08 & 1,01 & 0,65 & 0,83 & 6,39 & 8,25 & 7,32 & 1,94 & 1,75 & 1,85 \\
\hline 1991 & 1.847 .690 & 1,95 & 87,21 & 95,18 & 96,00 & 119,32 & 1,07 & 0,64 & 0,86 & 7,04 & 10,00 & 8,52 & 1,19 & 1,13 & 1,16 \\
\hline 1992 & 1.870 .588 & 1,97 & 65,64 & 95,91 & 96,54 & 106,46 & 1,21 & 0,71 & 0,96 & 7,64 & 8,81 & 8,23 & 1,44 & 1,44 & 1,44 \\
\hline 1993 & 1.912 .038 & 2,01 & 76,27 & 95,06 & 95,46 & 90,62 & 0,84 & 0,51 & 0,68 & 5,69 & 5,06 & 5,37 & 0,72 & 1,07 & 0,89 \\
\hline 1994 & 1.540 .269 & 1,62 & 163,38 & 97,16 & 97,35 & 125,43 & 1,06 & 0,53 & 0,79 & 6,33 & 5,71 & 6,02 & 0,56 & 1,29 & 0,92 \\
\hline 1995 & 1.480 .085 & 1,55 & 171,88 & 100,00 & 100,00 & 216,79 & 1,16 & 0,63 & 0,90 & 5,97 & 7,05 & 6,51 & 1,04 & 1,61 & 1,32 \\
\hline 1996 & 1.367 .896 & 1,43 & 139,41 & 101,09 & 100,93 & 153,00 & 1,21 & 0,64 & 0,93 & 6,17 & 7,81 & 6,99 & 0,71 & 1,51 & 1,11 \\
\hline 1997 & 1.406 .286 & 1,47 & 197,75 & 103,14 & 102,86 & 139,85 & 1,06 & 0,63 & 0,84 & 6,17 & 7,19 & 6,68 & 0,60 & 1,43 & 1,01 \\
\hline 1998 & 1.650 .431 & 1,72 & 156,06 & 105,01 & 104,64 & 156,18 & 0,92 & 0,69 & 0,81 & 6,65 & 6,05 & 6,35 & 0,50 & 1,30 & 0,90 \\
\hline 1999 & 1.658 .077 & 1,73 & 115,51 & 106,74 & 106,32 & 121,87 & 0,84 & 0,58 & 0,71 & 6,18 & 4,07 & 5,13 & 0,87 & 1,17 & 1,02 \\
\hline 2000 & 1.664 .207 & 1,74 & 98,22 & 110,09 & 109,64 & 93,26 & 0,74 & 0,52 & 0,63 & 6,03 & 2,92 & 4,48 & 0,60 & 1,08 & 0,84 \\
\hline 2001 & 2.017 .370 & 2,10 & 62,28 & 112,08 & 111,65 & 72,01 & 0,71 & 0,43 & 0,57 & 6,06 & 4,18 & 5,12 & 0,63 & 0,93 & 0,78 \\
\hline 2002 & 2.303 .330 & 2,40 & 48,25 & 112,50 & 112,15 & 58,03 & 0,71 & 0,57 & 0,64 & 0,00 & 3,81 & 1,91 & 0,00 & 0,85 & 0,43 \\
\hline
\end{tabular}

Fontes: Brasil (2003), IPEA (2003) e FAO (2003) 
Tabela 13. Dados utilizados nas regressões da demanda da França por café brasileiro

\begin{tabular}{|c|c|c|c|c|c|c|c|c|c|c|c|c|c|c|c|}
\hline Ano & $Y$ & Ypc & $\mathrm{Pr}$ & PIB & PIBpc & Pcs & Pio & Peo & Mo & Pic & $\mathrm{Pec}$ & Mc & Pis & Pes & Ms \\
\hline 61 & 26.000 & 0,68 & 143,99 & 2,89 & 32 & 66,79 & 0,17 & 0,27 &, 22 & 1,64 & 86 & 3,25 & 0,00 & 0,00 & 0,00 \\
\hline 1962 & & 69 & 142,30 & & & 5 & 1 & 5 & 3 & 1,62 & 50 &, 56 & 00 & $0, C 0$ &, 00 \\
\hline 1963 & 639.000 & 0,81 & 144,48 & 36,95 & 5,16 & 158,87 & 0,10 & 0,14 & 0,12 & 1,65 & 9,00 & 5,32 & 0,00 & 0,00 & 0,00 \\
\hline 1964 & 423.000 & 0,53 & 190,31 & 39,37 & 47,49 & 197,00 & 0,14 & 0,15 & 0,14 & 1,72 & 10,50 & 6,11 & 0,00 & 0,00 & 00 \\
\hline 1965 & 488.000 & 0,60 & 192,05 & 41,25 & 19 & 169,83 & 0,16 & 0,22 & 0,19 & 1,83 & 6,00 & 3,91 & 0,00 & 0,00 & 0,00 \\
\hline 1966 & 569 & 0,69 & 166,59 & 43,40 & 24 & 14 & 0,24 & 2,80 & 1,52 & 1,78 & 5,57 & 3,67 & 0,00 & 0,00 & 0,00 \\
\hline 1967 & 578.917 & 0,70 & 158,01 & 45,43 & 53,19 & 177,22 & 0,28 & 0,27 & 0,28 & 1,80 & 7,40 & 4,60 & 0,00 & 0,00 & 0,00 \\
\hline 1968 & 623.333 & 0,75 & 152,96 & 47,37 & 55,04 & 170,14 & 0,28 & 0,23 & 0,26 & 1,79 & 5,33 & 3,56 & 0,00 & 0,00 & 0,00 \\
\hline 1969 & 902.568 & 1,07 & 164,08 & 50,68 & 58,47 & 168,32 & 0,29 & 0,21 & 0,25 & 1,87 & 3,68 & 2,77 & 0,00 & 0,00 & 0,00 \\
\hline 1970 & 706 & 0,83 & 222,98 & 33 &, 21 & 10 & 0,31 & 0,21 & 0,26 & 1,87 & 12 & 2,65 & 0,00 & 0,00 &, 00 \\
\hline 1971 & 570.891 & 0,67 & 155,36 & 56,93 & 64,68 & 180,98 & 0,34 & 0,23 & 0,29 & 2,07 & 3,08 & 2,58 & 0,00 & 0,00 & 0,00 \\
\hline 1972 & 694.624 & 0,81 & 186,75 & 59,46 & 67,02 & 186,71 & 0,28 & 0,16 & 0,22 & 2,16 & 4,45 & 3,30 & 0,00 & 0,00 & 0,00 \\
\hline 1973 & 1.104 .478 & 1,27 & 194,51 & 62,69 & 70,11 & 198,58 & 0,32 & 0,19 & 0,26 & 2,38 & 3,52 & 2,95 & 0,00 & 0,00 & 0,00 \\
\hline 1974 & 9 & 0,88 & 168,97 & 64,64 & 71,76 & 182,37 & 0,30 & 0,22 & 1,26 & 2,44 & 83 & 2,64 & 0,00 & 0,00 & 0,00 \\
\hline 1975 & 806.709 & 0,92 & 132,79 & 64,46 & 71,11 & 170,90 & 0,29 & 0,29 & 0,29 & 2,94 & 3,68 & 3,31 & 0,00 & 0,00 & 0,00 \\
\hline 1976 & 566.754 & 0,64 & 320,09 & 67,19 & 73,73 & 261,79 & 0,32 & 0,32 & 0,32 & 2,58 & 5,25 & 3,92 & 0,92 & 0,51 & 0,71 \\
\hline 1977 & 560.630 & 0,63 & 503,37 & 69,36 & 75,77 & 542,70 & 0,39 & 0,49 & 0,44 & 3,78 & 5,82 & 4,80 & 0,59 & 0,75 & 0,67 \\
\hline 1978 & 543 & 0,61 & 335,89 & 71,68 & 77,99 & 375,39 & 0,48 & 0,52 & 0,50 & 4,59 & 7,91 & 6,25 & 1,04 & 0,76 & 0,90 \\
\hline 1979 & 504 & 0,56 & 324,81 & 74,00 & 80,19 & 322,66 & 0,48 & 0,57 & 0,53 & 4,80 & 8,17 & 6,48 & 86 & 0,95 & 0,91 \\
\hline 1980 & 806.389 & 0,90 & 264,63 & 75,21 & 81,16 & 297,14 & 0,47 & 0,65 & 0,56 & 4,97 & 8,19 & 6,58 & 0,92 & 0,97 & 0,95 \\
\hline 1981 & 777 & 0,86 & 137,47 & 76,09 & 81,72 & 186,64 & 0,40 & 0,55 & 0,47 & 4,47 & 8,06 & 6,27 &, 51 & 0,84 & 0,68 \\
\hline 1982 & 906 & 1,00 & 157,56 & 78,03 & 83,38 & 188,28 & 0,37 & 0,51 & 0,44 & 4,31 & 7,49 & 5,90 & 0,64 & 0,75 & 0,69 \\
\hline 1983 & 863 & 0,95 & 167,84 & 78,57 & 83,51 & 195,68 & 0,40 & 0,62 & 0,51 & 3,98 & 5,14 & 4,56 & 0,96 & 0,75 & 0,86 \\
\hline 1984 & 1.106 .708 & 1,21 & 188,30 & 79,60 & 84,16 & 215,07 & 0,36 & 0,52 & 0,44 & 4,46 & 6,62 & 5,54 & 1,04 & 0,80 & 0,92 \\
\hline 1985 & 1.125 .101 & 1,22 & 167,61 & 81,10 & 85,29 & 214,98 & 0,33 & 0,45 & 0,39 & 4,13 & 8,55 & 6,34 &, 09 & 1,00 & 1,04 \\
\hline 1986 & 384.798 & 0,42 & 306,81 & 83,14 & 86,98 & 270,97 & 0,50 & 0,52 & 0,51 & 4,47 & 11,53 & 8,00 & 0,93 & 1,08 & 1,01 \\
\hline 1987 & 841.891 & 0,90 & 143,36 & 85,01 & 88,47 & 192,96 & 0,57 & 0,59 & 0,58 & 5,02 & 12,19 & 8,61 & 1,11 & 0,85 & 0,98 \\
\hline 1988 & 698.609 & 0,75 & 161,83 & 88,84 & 91,98 & 171,51 & 0,59 & 0,64 & 0,61 & 5,09 & 13,08 & 9,08 & 2,04 & 0,77 & 1,40 \\
\hline 1989 & 837.716 & 0,89 & 119,75 & 92,71 & 95,49 & 149,21 & 0,56 & 0,56 & 0,56 & 4,63 & 11,99 & 8,31 & 1,86 & 1,11 & 1,49 \\
\hline 1990 & 667.096 & 0,71 & 89,28 & 95,05 & 97,40 & 101,43 & 0,54 & 0,76 & 0,65 & 5,50 & 13,97 & 9,74 & 1,90 & 1,09 & 1,50 \\
\hline 1991 & 709.981 & 0,75 & 88,68 & 96,09 & 97,96 & 94,38 & 0,55 & 0,70 & 0,62 & 4,86 & 12,74 & 8,80 & 1,12 & 0,93 & 1,02 \\
\hline 1992 & 544.096 & 0,57 & 61,02 & 97,28 & 98,67 & 03 & 0,63 & 0,72 & 0,68 & 4,97 & 15,06 & 10,01 & 1,17 & 1,27 & 1,22 \\
\hline 1993 & 589.934 & 0,61 & 73,17 & 96,42 & 97,31 & 81,29 & 0,59 & 0,67 & 0,63 & 4,19 & 14,58 & 9,39 & 1,01 & 0,88 & 0,95 \\
\hline 1994 & 467.140 & 0,48 & 148,90 & 98,15 & 98,59 & 146,57 & 0,60 & 0,68 & 0,64 & 4,00 & 11,30 & 7,65 & 0,75 & 0,72 & 0,73 \\
\hline 1995 & 397.326 & 0,41 & 161,96 & 100,00 & 100,00 & 199,98 & 0,65 & 0,77 & 0,71 & 4,37 & 11,94 & 8,15 & 0,87 & 0,61 & 0,74 \\
\hline 1996 & 391.980 & 0,40 & 125,20 & 101,07 & 100,65 & 140,14 & 0,62 & 0,74 & 0,68 & 3,62 & 12,89 & 8,25 & 0,87 & 0,83 & 0,85 \\
\hline 1997 & 480.302 & 0,49 & 197,93 & 102,98 & 102,16 & 162,38 & 0,66 & 0,64 & 0,65 & 3,80 & 12,00 & 7,90 & 0,68 & 0,82 & 0,75 \\
\hline 1998 & 506.634 & 0,52 & 145,09 & 106,56 & 105,32 & 154,88 & 0,47 & 0,67 & 0,57 & 4,87 & 11,81 & 8,34 & 0,60 & 0,74 & 0,67 \\
\hline 1999 & 731.144 & 0,74 & 109,67 & 109,86 & 108,16 & 111,52 & 0,46 & 0,61 & 0,54 & 5,53 & 10,27 & 7,90 & 0,62 & 0,74 & 0,68 \\
\hline 2000 & 612.328 & 0,62 & 93,60 & 114,03 & 111,81 & 88,82 & 0,87 & 1,45 & 1,16 & 4,16 & 7,50 & 5,83 &, 59 & 0,60 & 0,60 \\
\hline 2001 & 910.036 & 0,92 & 56,14 & 116,42 & 113,63 & 63,06 & 0,43 & 0,54 & 0,48 & 4,33 & 9,66 & 6,99 & 0,60 & 0,59 & 0,59 \\
\hline 2002 & 949.083 & 0,95 & 47,75 & 117,83 & 114,46 & 57,84 & 0,49 & 0,56 & 0,52 & 4,83 & 9,09 & 6,96 & 0,59 & 0,86 & 0,72 \\
\hline
\end{tabular}

Fontes: Brasil (2003), IPEA (2003) e FAO (2003) 
Tabela 14. Dados utilizados nas regressões da demanda do Japão por café brasileiro

\begin{tabular}{|c|c|c|c|c|c|c|c|c|c|c|c|c|c|c|c|}
\hline Ano & $Y$ & Ypc & Pr & PIB & PIBpc & os & Sio & eo & Mo & Pic & $\mathrm{Pec}$ & Mc & is & es & Ms \\
\hline & .000 & 0,03 & 09 &, 21 & & 5,29 & 0,25 & & 20 & 1,40 & 9 &, 00 & 10 & 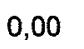 & 00 \\
\hline & & & & & & & & & & 2 & 1 & 92 & 10 & 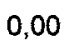 & \\
\hline & & 0,08 &, 79 & & & & 33 & & & 1,19 & 72 & 0,96 & 0 & 00 & \\
\hline 1964 & 0 & 0,02 & 211,65 & 25,26 & & 161,18 & 0,43 & 0,14 & 0,28 & 1,34 & 64 &, 99 & 0,00 & 0 &, 00 \\
\hline 100 & 100 & 0,03 & 29 & 23,98 & 43 & 26 & 1,31 & 7 & 4 & 1,36 & 62 &, 99 & U & 0 & \\
\hline & & 0,04 & & 26 & & & 0,36 & & & 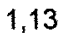 & 61 & 0,87 & 0 & & \\
\hline & & 5 & & & & & 10 & & & & 57 & 2 & 00 & 00 & \\
\hline 1968 & 10 & 0,06 & 169,08 & 32,9 & & & 0,43 & 25 & 34 & 1,52 & 64 & 1,08 & 0,00 & 00 & 0,0 \\
\hline 1968 & & 0,09 & 193,42 & 36,88 & 89 & 58 & 0,33 & 23 & 0,28 & 1,06 & 0,76 & 0,91 & 0,00 & 00 & 5,0 \\
\hline- & & 0,06 & 0,48 & 40 & & & 0,39 & 3 & & 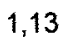 & 71 &,$\sqrt{20}$ & 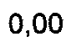 & 00 & , \\
\hline 197 & & 0,05 & 32 & 42,06 & & & 0,45 & 11 & 33 & 1,09 & 0,78 & 0,93 & 0,00 & 00 & \\
\hline 197 & & 0,09 & 5 & 45,5 & & & 0,51 & 30 & 0,40 & 1,40 & 0,6 & 1,03 & 0 & 10 & 0,0 \\
\hline 197 & 56 & 0,31 & $18 \uparrow, 17$ & 49,1 & 76 & 78 & 0,33 & 5 & 9 & 1,57 & ,61 & 1,09 & 0 & 0,00 &, 0 \\
\hline 19 & & 0,12 & 99 & 48, & & & 0, & 3. & & 1,97 & , 56 & $T, \angle T$ & 0,0 & , & , \\
\hline 19 & & 0,16 & 168,22 & 49,8 & & & 1,29 & 0,63 & & 34 & 0,56 & 1,20 & 00 & 00 & \\
\hline 197 & & 0,32 & 32 & 52, & & & 1,01 & \$0 & & 1,66 & 0,66 & 6 & 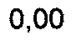 & 10 & \\
\hline 197 & & 0,25 & 515,36 & 54,9 & 58 & & 0,88 & 66 & 7 & 2 & 87 & 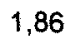 & . & 00 &, 0 \\
\hline 15 & & 0,21 & 326,31 & 57,7 & 10 & 96 & 0,50 & 0,69 & & & 84 & 10 & 0,00 & 0,00 & 0,0 \\
\hline 19 & & 0,23 & 4,96 & 60 & 82 & 7 & 0,62 & 2 & & 54 & ,88 & 2,21 & 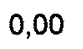 & 00 & \\
\hline 198 & & 0,34 & 284,03 & 63,0 & 6 & 2 & 0,61 & 0,69 & 5 & 86 & 0,98 & 2,42 & 0,00 & 0 & 0 \\
\hline 198 & & 0,36 & & 64 & & & 0, & & & & 1,14 & 37 & & & 0,0 \\
\hline 198 & 57.811 & 0,43 & 11,88 & 66,68 & 56 & 5 & 0,6 & 0,70 & & 36 & 1,12 & 2,24 & . & &, 0 \\
\hline 198 & & 0,53 & 170,43 & 67,7 & 4 & & 3 & 0 & 57 & 2 & 1,11 & 27 & 0,00 &, 00 & \\
\hline 198 & & 56 & 480 & 69,8 & & & 0,61 & 73 & 7 & 7 & 1,21 & 2,54 & 0 & 0 & 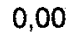 \\
\hline 198 & & 0,62 & 18 & 73 & & & 0,62 & & & & 1 & 2,58 & & & , \\
\hline 198 & & 0,34 & 3 & 75 & & & 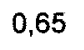 & 0,84 & & 3 & 31 & 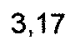 & 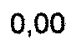 & & 0,0 \\
\hline 1987 & 03 & 0,51 & 149,04 & 78,4 & 80,63 & 208,60 & 0,68 & 0,77 & 0,73 & 3,99 & 2,39 & 3,19 & 0,00 & 0,0 & 0,0 \\
\hline 1988 & & 0,48 & 4,08 & 83,7 & 85,75 & 0 & 0,72 & 0,91 & 11 & 4,16 & 2,63 & 3,40 & 0,00 & 00 & 0,0 \\
\hline 1989 & 9 & 0,59 & 123,43 & 88,2 & & 20 & 0,73 & 1,05 & 9 & 0 & 4,23 & 4,04 & 0,00 & 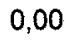 & 0,0 \\
\hline 1990 & 6 & 0,44 & & 92,8 & 94,30 & & 0,70 & 1,10 & & 3, & 9,34 & 6,67 & 0,0 & 0,0 & $0, C$ \\
\hline 1991 & 389 & 0,55 & 98,72 & 95,95 & 97,11 & 130,38 & 0,72 & 1,43 & 1,08 & 3,78 & 12,66 & 8,22 & 0,00 & 0,0 & 0,0 \\
\hline 1992 & & 0,55 & 72,09 & 96,8 & 97,72 & & 0,73 & 1,99 & 1,36 & 3,86 & 13,40 & 8,63 & 0,00 & 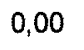 & 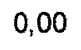 \\
\hline 1993 & & 0,64 & 76,86 & 97,0 & 97,62 & 112,59 & 0,71 & 1,74 & 1,22 & 3,91 & 15,23 & 9,57 & 0,00 & 0 & 0,0 \\
\hline 199 & 8 & 0,63 & 165,1 & 98,1 & 98,43 & 171,29 & 0,63 & 2,4 & 1.5 & 3,96 & 15,95 & 9,96 & 0,00 & 0,0 & 0,0 \\
\hline 199 & 192 & 0,50 & 184,95 & 100,00 & 100,00 & 227,77 & 0,61 & 3,19 & 1,90 & 4,05 & 15,82 & 9,93 & 0,00 & 0,00 & 0,0 \\
\hline 1996 & & 0,58 & 140,70 & & & & 0,67 & 2,43 & 1,55 & 4,14 & & 9,61 & 0,00 & 00 & 0,0 \\
\hline 1997 & 1.217 .161 & 0,58 & 199,30 & 105,42 & 104,85 & 191,95 & 0,65 & 2,24 & 1,45 & 3,73 & 14,05 & 8,89 & 0,00 & 0,00 & 0,0 \\
\hline 199 & 394.019 & 0,66 & 162,7 & 104,1 & 103,34 & 92,82 & 0,68 & 1,9 & 1,33 & 3,98 & 12,55 & 8,26 & 0,00 & 0,00 & 0.0 \\
\hline $19 s$ & & 0,7 & 116 & 104 & 103,26 & & 0,78 & 1,8 & 1,38 & 3 & 14,42 & 9,01 & 0,00 & 0,00 & 0,0 \\
\hline 200 & 2.794 & 0,68 & 100,72 & 107,26 & 105,94 & 120,29 & 1,15 & 2,55 & 1,85 & 3,59 & 15,88 & 9,73 & 0,00 & 0,00 & n \\
\hline 2001 & 573.272 & 0,74 & 61,98 & 107,69 & 106,17 & 21 & 1,15 & 2,55 & 1,85 & 3,46 & 15,96 & 9,71 & 0,00 & 00 & 0,0 \\
\hline 200 & 327.198 & 0,77 & 54,20 & 107,32 & 105,63 & 1,85 & 1,06 & 2,27 & 1,67 & 0,00 & 14,69 & 7,34 & 0,00 & 0,00 &, 0 \\
\hline
\end{tabular}

Fontes: Brasil (2003), IPEA (2003) e FAO (2003) 
Tabela 15. Dados utilizados nas regressões da demanda doméstica por café brasileiro

\begin{tabular}{|c|c|c|c|}
\hline Ano & Cpc & $\mathrm{Pr}$ & Pibpc \\
\hline 1961 & 4,81 & 80,37 & 3,50 \\
\hline 1962 & 5,03 & 86,15 & 3,63 \\
\hline 1963 & 5,30 & 82,44 & 3,55 \\
\hline 1964 & 5,74 & 144,54 & 3,56 \\
\hline 1965 & 6,05 & 100,10 & 3,55 \\
\hline 1966 & 5,87 & 70,82 & 3,68 \\
\hline 1967 & 6,07 & 63,90 & 3,73 \\
\hline 1968 & 5,99 & 79,00 & 3,98 \\
\hline 1969 & 5,83 & 99,45 & 4,24 \\
\hline 1970 & 5,76 & 143,28 & 4,55 \\
\hline 1971 & 5,58 & 110,09 & 4,92 \\
\hline 1972 & 4,12 & 127,83 & 5,35 \\
\hline 1973 & 4,06 & 163,99 & 5,93 \\
\hline 1974 & 4,39 & 161,12 & 6,23 \\
\hline 1975 & 3,98 & 173,59 & 6,38 \\
\hline 1976 & 3,62 & 342,49 & 6,84 \\
\hline 1977 & 3,86 & 433,15 & 7,00 \\
\hline 1978 & 3,62 & 262,18 & 7,16 \\
\hline 1979 & 3,47 & 229,14 & 7,46 \\
\hline 1980 & 3,73 & 224,04 & 7,96 \\
\hline 1981 & 3,77 & 146,72 & 7,46 \\
\hline 1982 & 3,57 & 152,52 & 7,36 \\
\hline 1983 & 3,43 & 136,28 & 6,99 \\
\hline 1984 & 3,12 & 151,26 & 7,22 \\
\hline 1985 & 2,83 & 240,43 & 7,64 \\
\hline 1986 & 2,43 & 461,53 & 8,05 \\
\hline 1987 & 2,53 & 127,19 & 8,18 \\
\hline 1988 & 2,44 & 100,45 & 8,04 \\
\hline 1989 & 2,64 & 107,92 & 8,15 \\
\hline 1990 & 3,39 & 78,15 & 7,67 \\
\hline 1991 & 3,47 & 70,79 & 7,63 \\
\hline 1992 & 3,58 & 62,51 & 7,47 \\
\hline 1993 & 3,62 & 75,74 & 7,72 \\
\hline 1994 & 3,65 & 130,56 & 8,06 \\
\hline 1995 & 3,88 & 112,96 & 8,28 \\
\hline 1996 & 4,18 & 93,35 & 8,38 \\
\hline 1997 & 4,31 & 131,58 & 8,54 \\
\hline 1998 & 4,52 & 104,87 & 8,44 \\
\hline 1999 & 4,65 & 103,74 & 8,39 \\
\hline 2000 & 4,78 & 86,13 & 8,64 \\
\hline 2001 & 4,87 & 51,79 & 8,64 \\
\hline 2002 & 4,83 & 45,67 & 8,69 \\
\hline
\end{tabular}

Fontes: IBC (1989), IEA (2001), ABIC (2003) e IPEA (2003) 
Tabela 16. Dados de re-exportações de café verde (em sacas), utilizados nas regressões que incluíram as re-exportações de café como variável independente

\begin{tabular}{|c|c|c|c|c|c|}
\hline Ano & EUA & Alemanha & Itália & França & Japão \\
\hline 1961 & 449.067 & 6.267 & 33 & 2.900 & 0 \\
\hline 1962 & 609.300 & 9.017 & 0 & 5.150 & 1.000 \\
\hline 1963 & 544.800 & 9.333 & 350 & 6.117 & 6.000 \\
\hline 1964 & 675.200 & 9.283 & 2.533 & 8.283 & 1.667 \\
\hline 1965 & 531.467 & 16.550 & 1.850 & 8.117 & 3.333 \\
\hline 1966 & 488.583 & 31.033 & 3.417 & 8.550 & 317 \\
\hline 1967 & 412.817 & 30.167 & 2.150 & 4.700 & 0 \\
\hline 1968 & 443.767 & 51.983 & 1.783 & 15.417 & 0 \\
\hline 1969 & 371.517 & 60.817 & 2.267 & 33.333 & 50 \\
\hline 1970 & 388.400 & 64.667 & 2.150 & 58.400 & 83 \\
\hline 1971 & 346.233 & 54.733 & 7.833 & 55.300 & 0 \\
\hline 1972 & 483.667 & 84.750 & 8.750 & 104.933 & 0 \\
\hline 1973 & 1.093 .467 & 149.617 & 7.717 & 153.233 & 0 \\
\hline 1974 & 1.315 .733 & 102.183 & 4.167 & 178.100 & 117 \\
\hline 1975 & 760.450 & 142.500 & 867 & 134.367 & 17 \\
\hline 1976 & 1.024 .817 & 126.133 & 767 & 155.033 & 0 \\
\hline 1977 & 1.575 .000 & 80.800 & 350 & 95.567 & 0 \\
\hline 1978 & 862.833 & 205.800 & 5.633 & 70.417 & 100 \\
\hline 1979 & 1.198 .950 & 374.250 & 1.533 & 142.833 & 100 \\
\hline 1980 & 1.136 .517 & 411.733 & 5.800 & 204.433 & 0 \\
\hline 1981 & 970.583 & 465.483 & 6.133 & 205.100 & 0 \\
\hline 1982 & 845.333 & 476.733 & 11.467 & 276.883 & 0 \\
\hline 1983 & 613.683 & 467.333 & 8.983 & 292.133 & 0 \\
\hline 1984 & 917.650 & 596.617 & 2.717 & 275.133 & 0 \\
\hline 1985 & 716.133 & 635.833 & 217 & 378.650 & 0 \\
\hline 1986 & 1.129 .133 & 709.733 & 850 & 364.533 & 0 \\
\hline 1987 & 875.300 & 1.001 .683 & 10.700 & 471.850 & 0 \\
\hline 1988 & 1.051 .633 & 1.219 .250 & 6.850 & 544.283 & 0 \\
\hline 1989 & 644.617 & 1.499 .800 & 17.017 & 637.133 & 0 \\
\hline 1990 & 454.333 & 1.558 .550 & 51.533 & 668.333 & 17 \\
\hline 1991 & 556.617 & 1.364 .250 & 6.617 & 675.267 & 0 \\
\hline 1992 & 701.050 & 1.311 .250 & 16.767 & 605.317 & 0 \\
\hline 1993 & 1.040 .733 & 1.112 .317 & 41.233 & 500.083 & 0 \\
\hline 1994 & 1.716 .650 & 1.160 .667 & 55.567 & 669.233 & 0 \\
\hline 1995 & 1.018 .883 & 1.174 .017 & 36.983 & 599.900 & 0 \\
\hline 1996 & 894.350 & 1.474 .667 & 54.183 & 648.250 & 0 \\
\hline 1997 & 1.054 .267 & 1.777 .783 & 63.783 & 609.800 & 0 \\
\hline 1998 & 1.149 .483 & 1.943 .550 & 66.100 & 660.783 & 0 \\
\hline 1999 & 701.750 & 1.872 .667 & 84.300 & 638.633 & 17 \\
\hline 2000 & 678.433 & 2.784 .500 & 123.850 & 623.667 & 100 \\
\hline 2001 & 784.517 & 2.585 .400 & 127.500 & 566.283 & 33 \\
\hline 2002 & 797.250 & 3.243 .317 & 75.867 & 493.267 & 1.850 \\
\hline
\end{tabular}

Fonte: FAO (2003) 


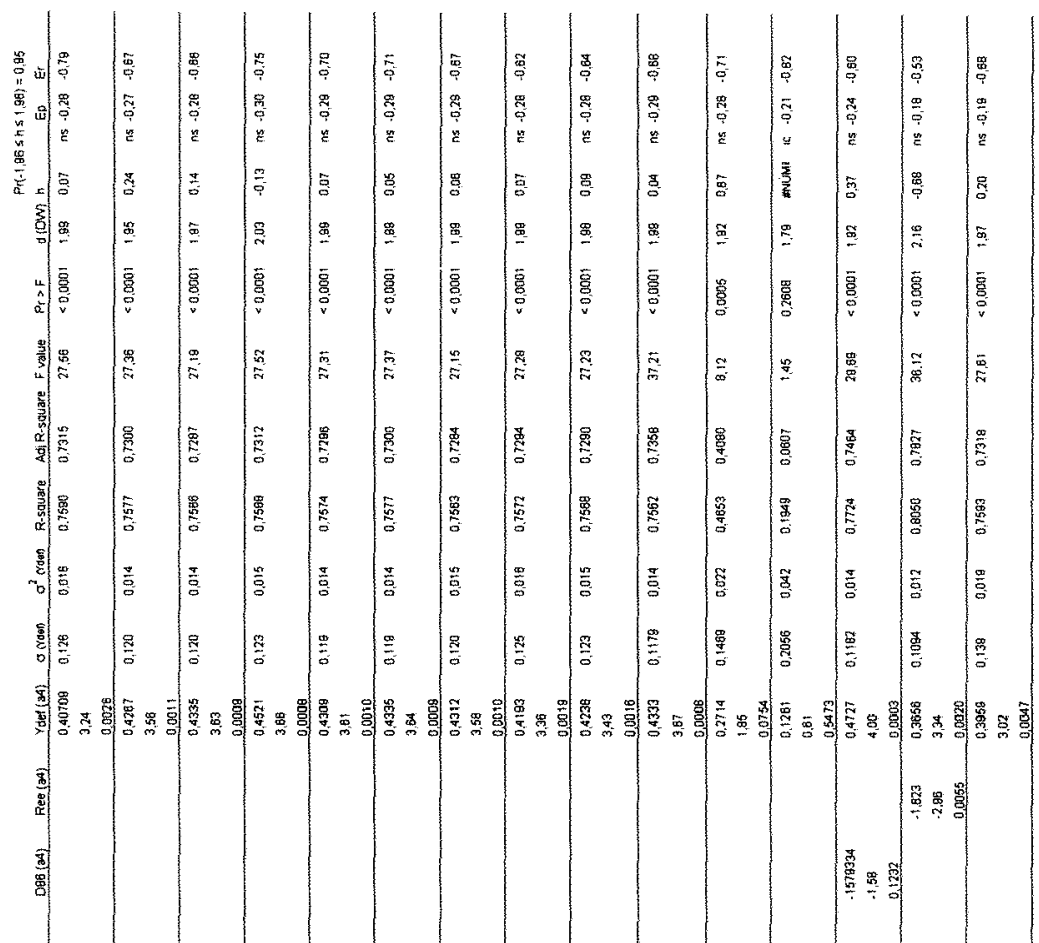

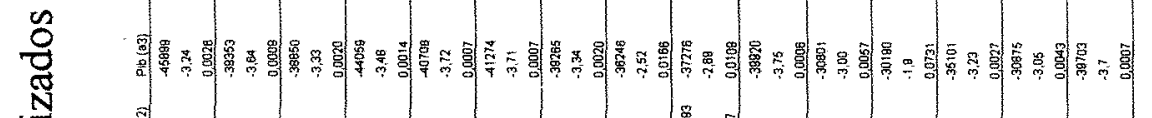

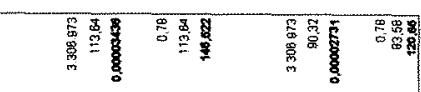

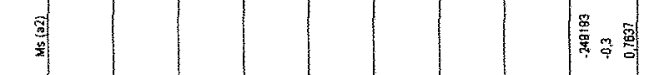

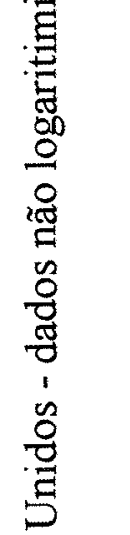

호ำ

\ \

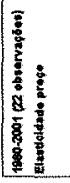

99

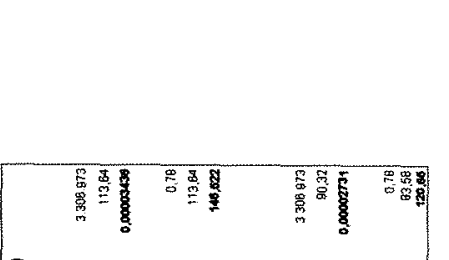




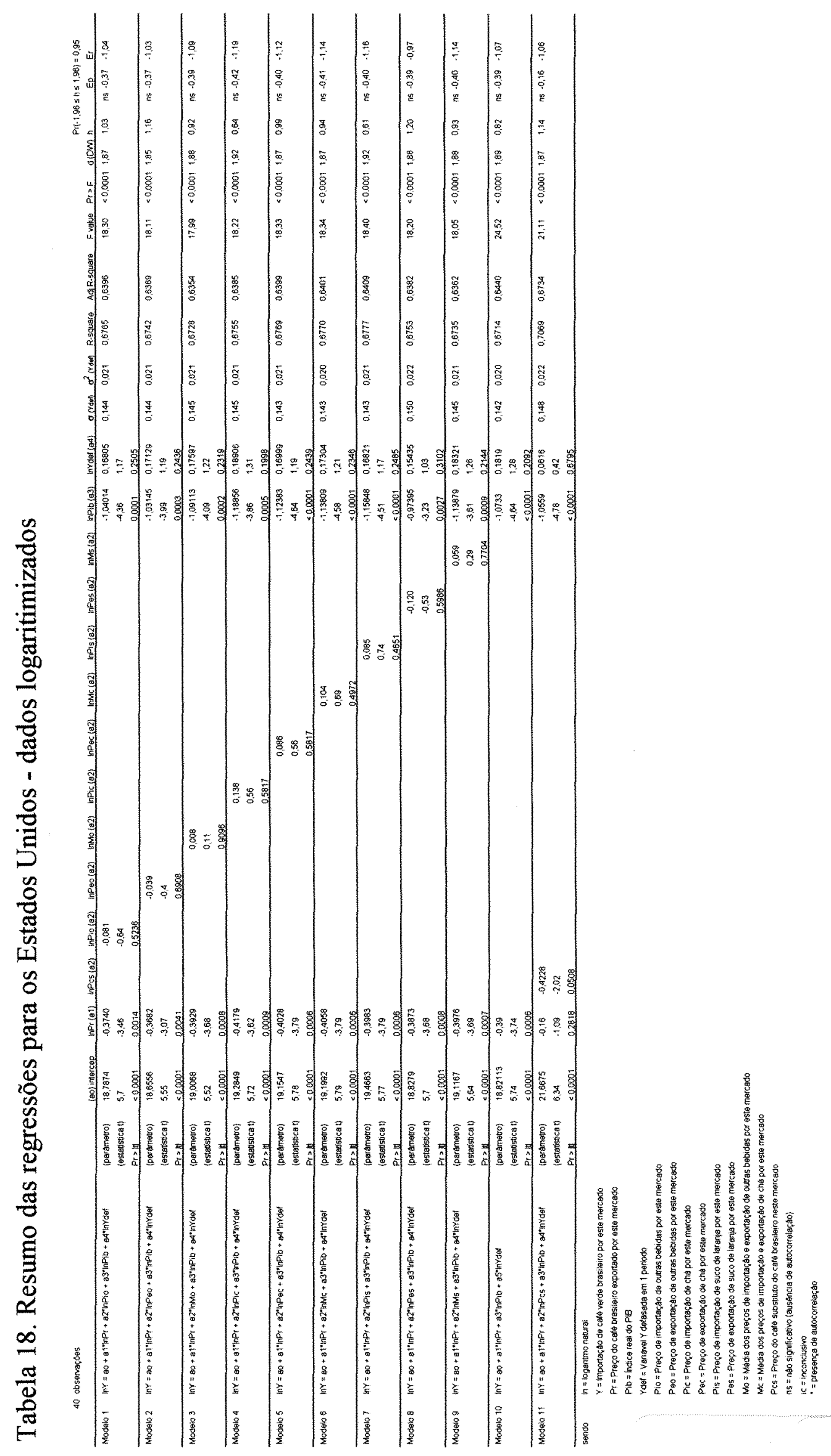




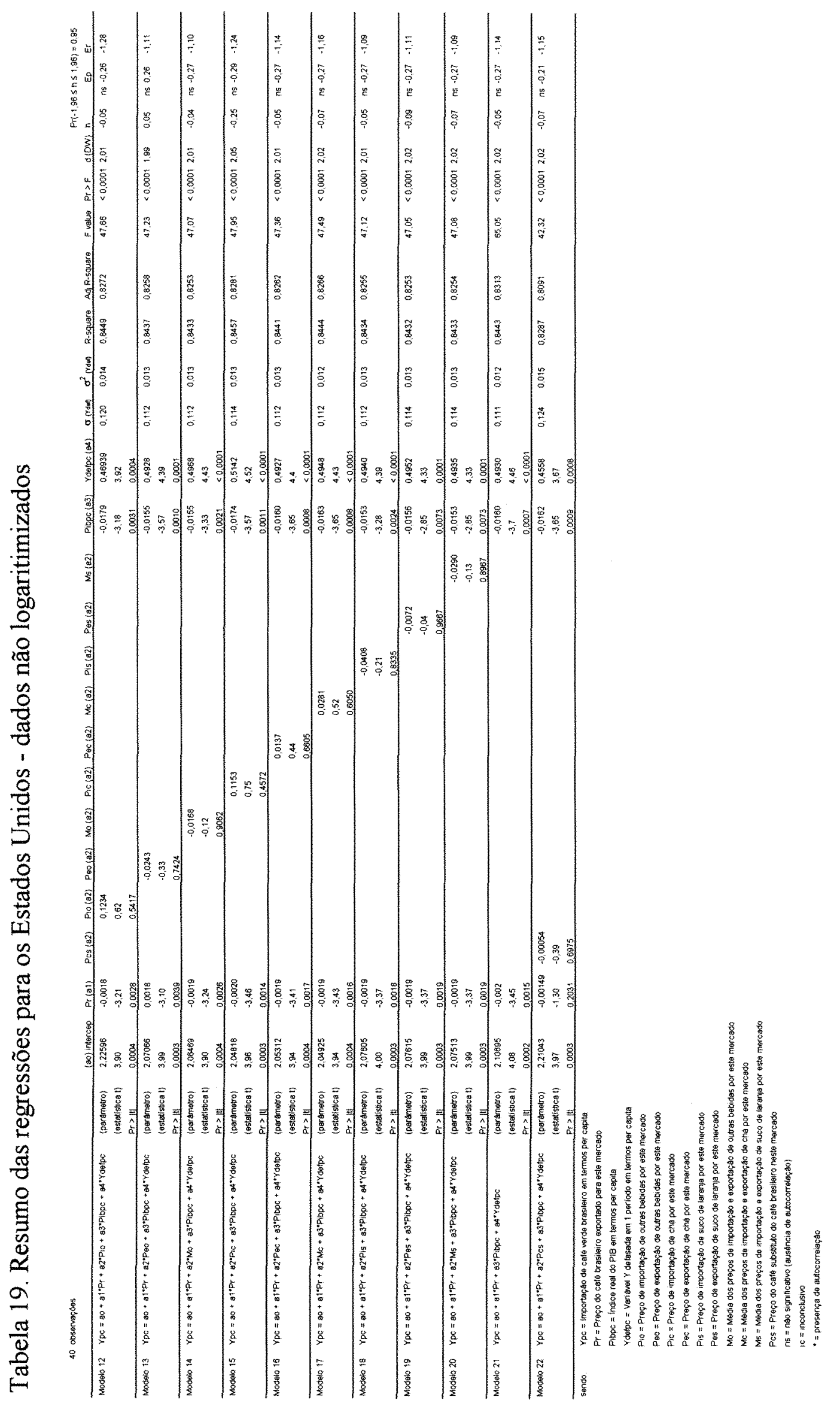




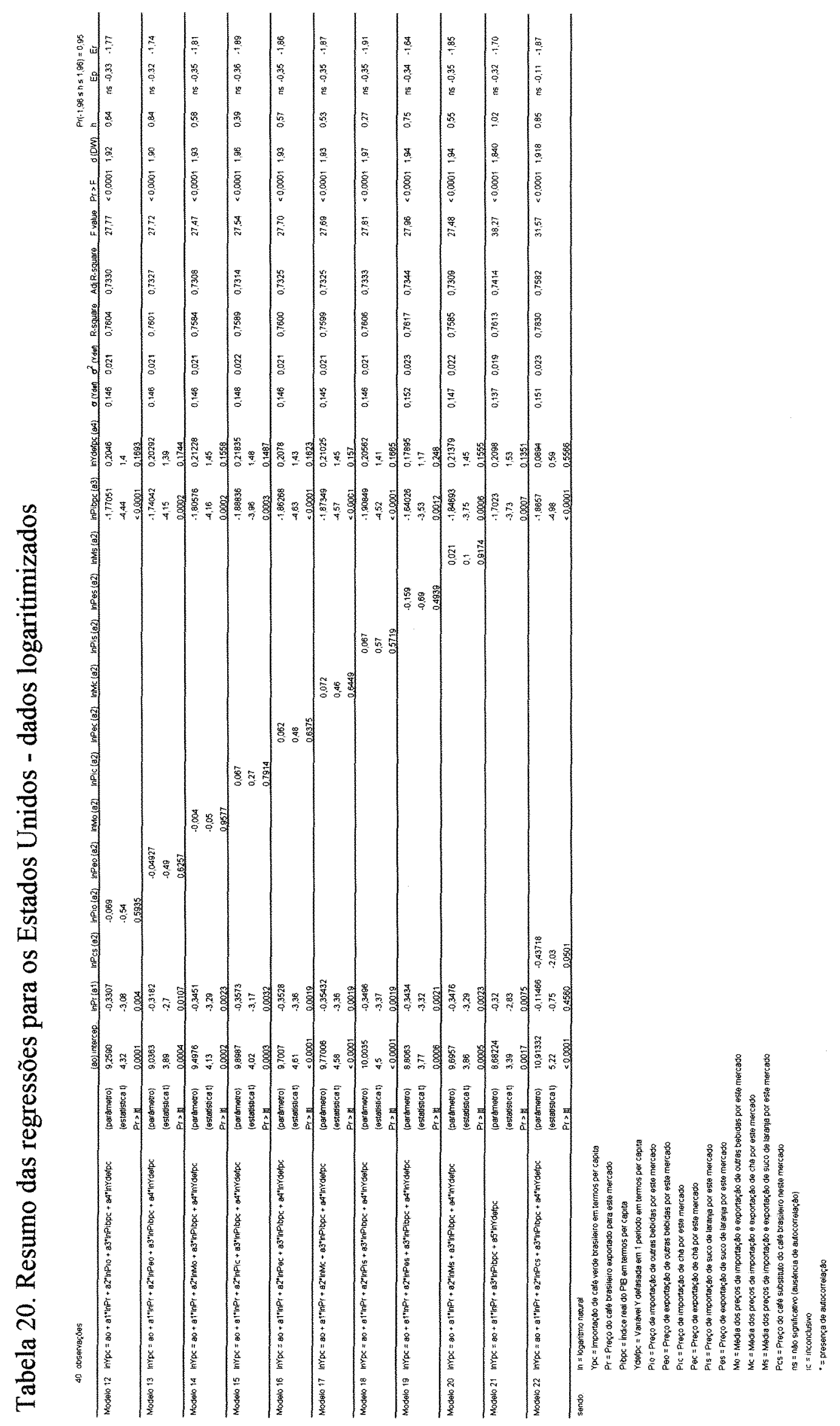




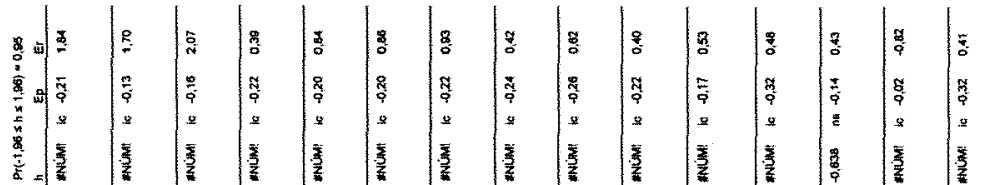

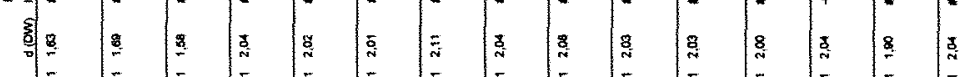

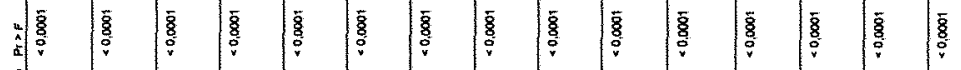

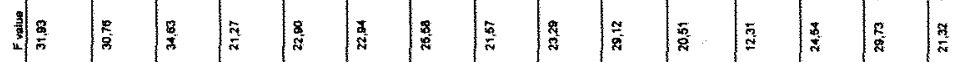

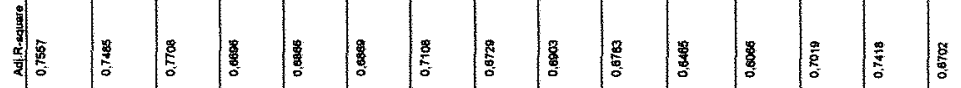

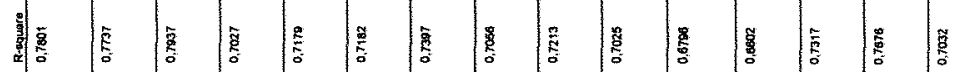

ว

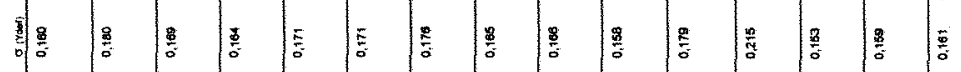

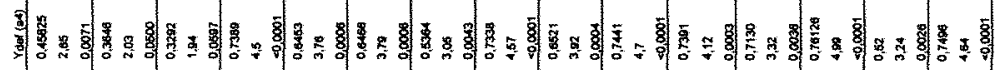

s.

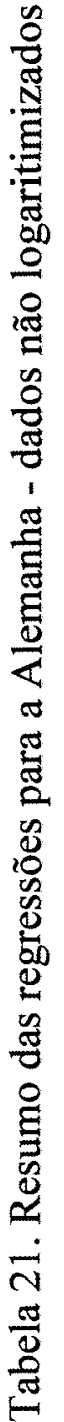

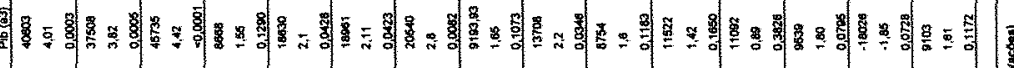

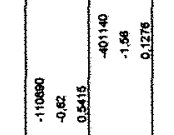

然数

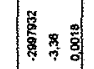

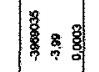

量

量量

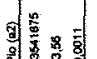

a

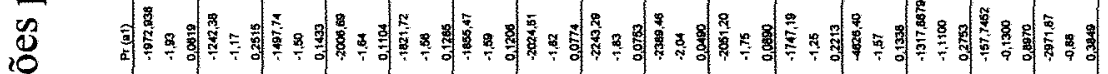

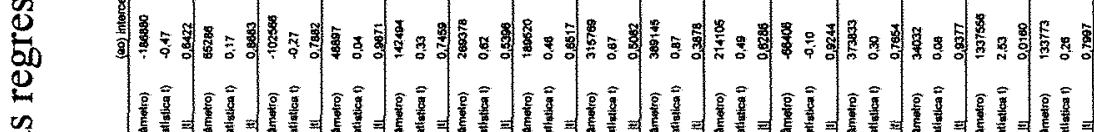

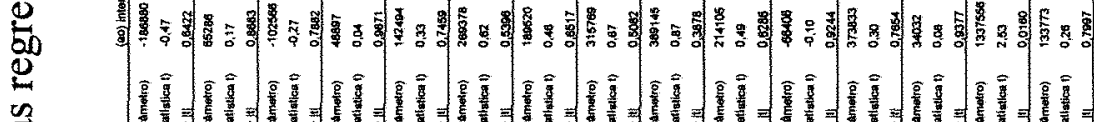

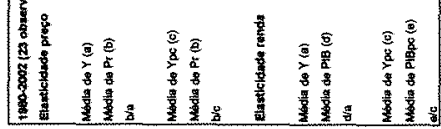

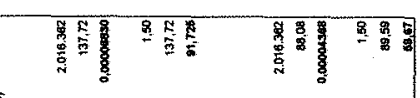

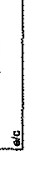

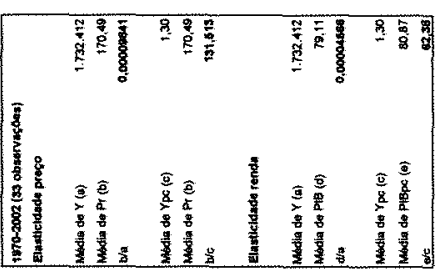

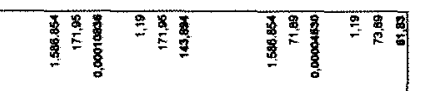

赔

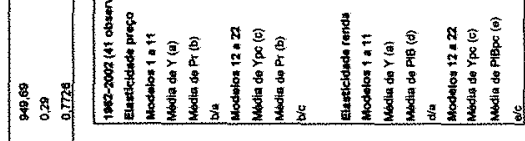

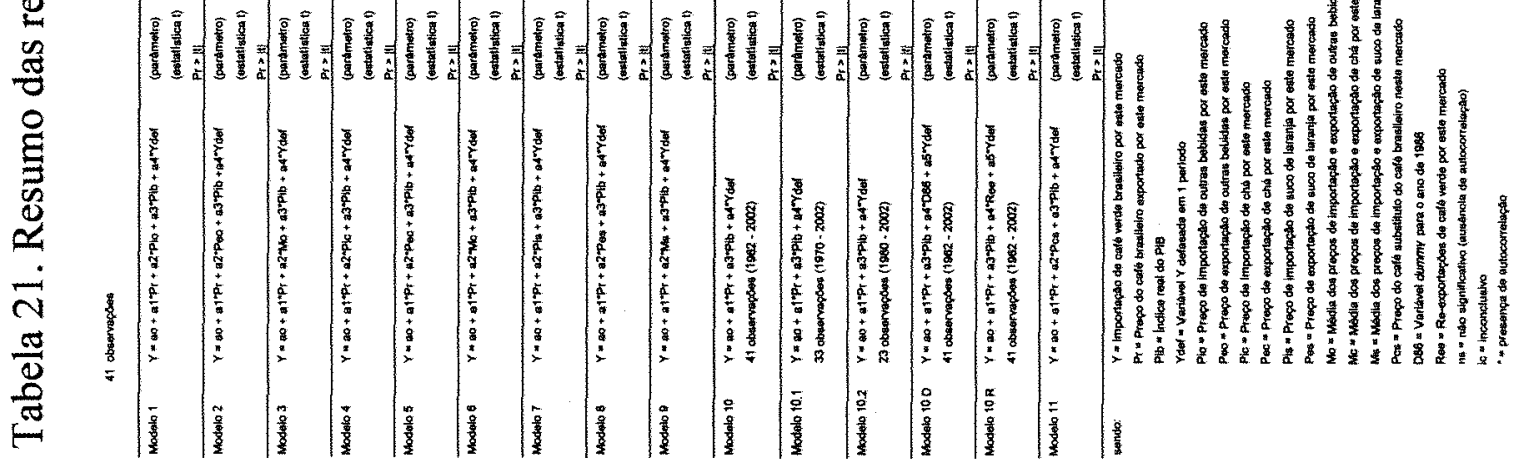




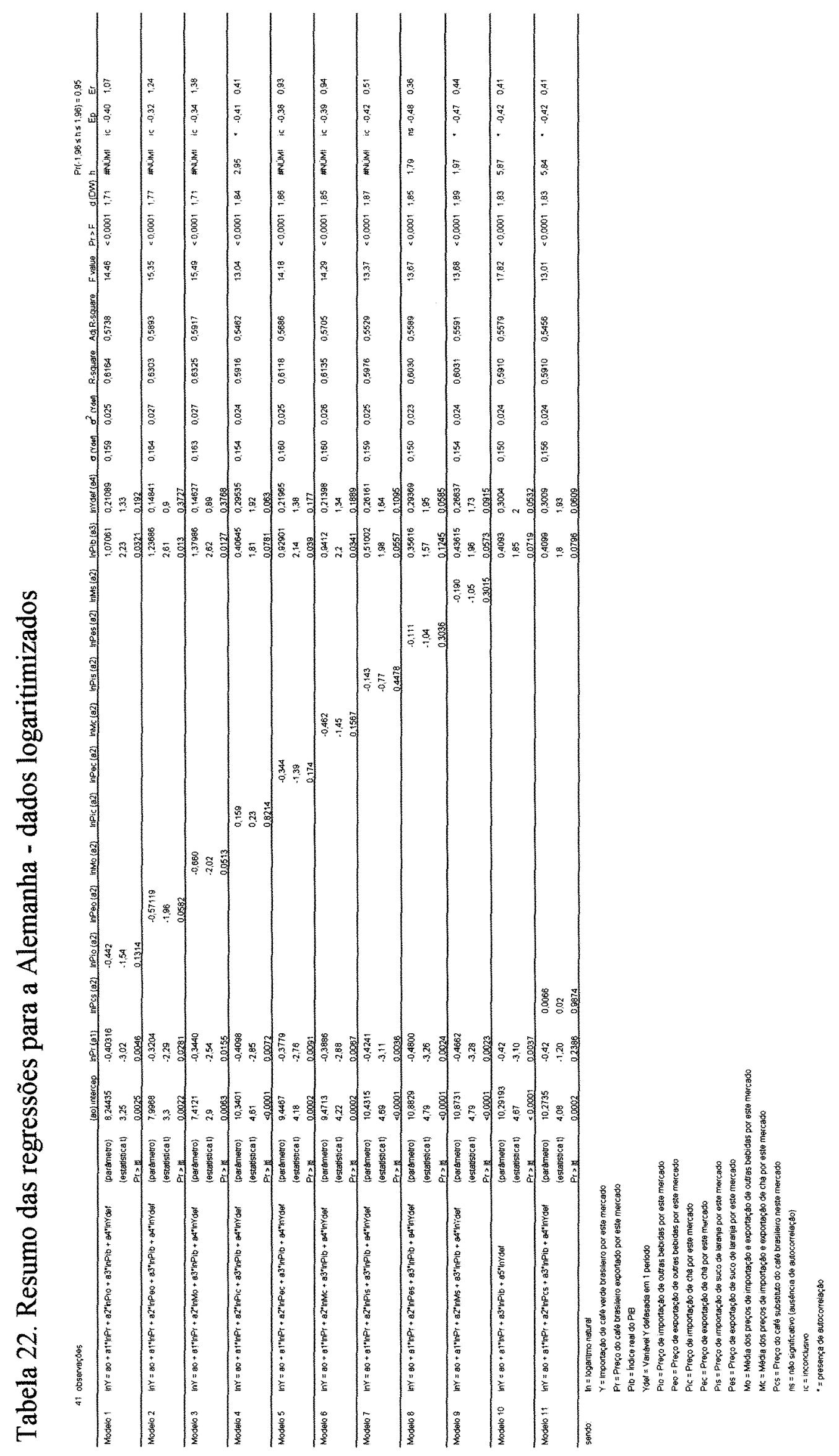




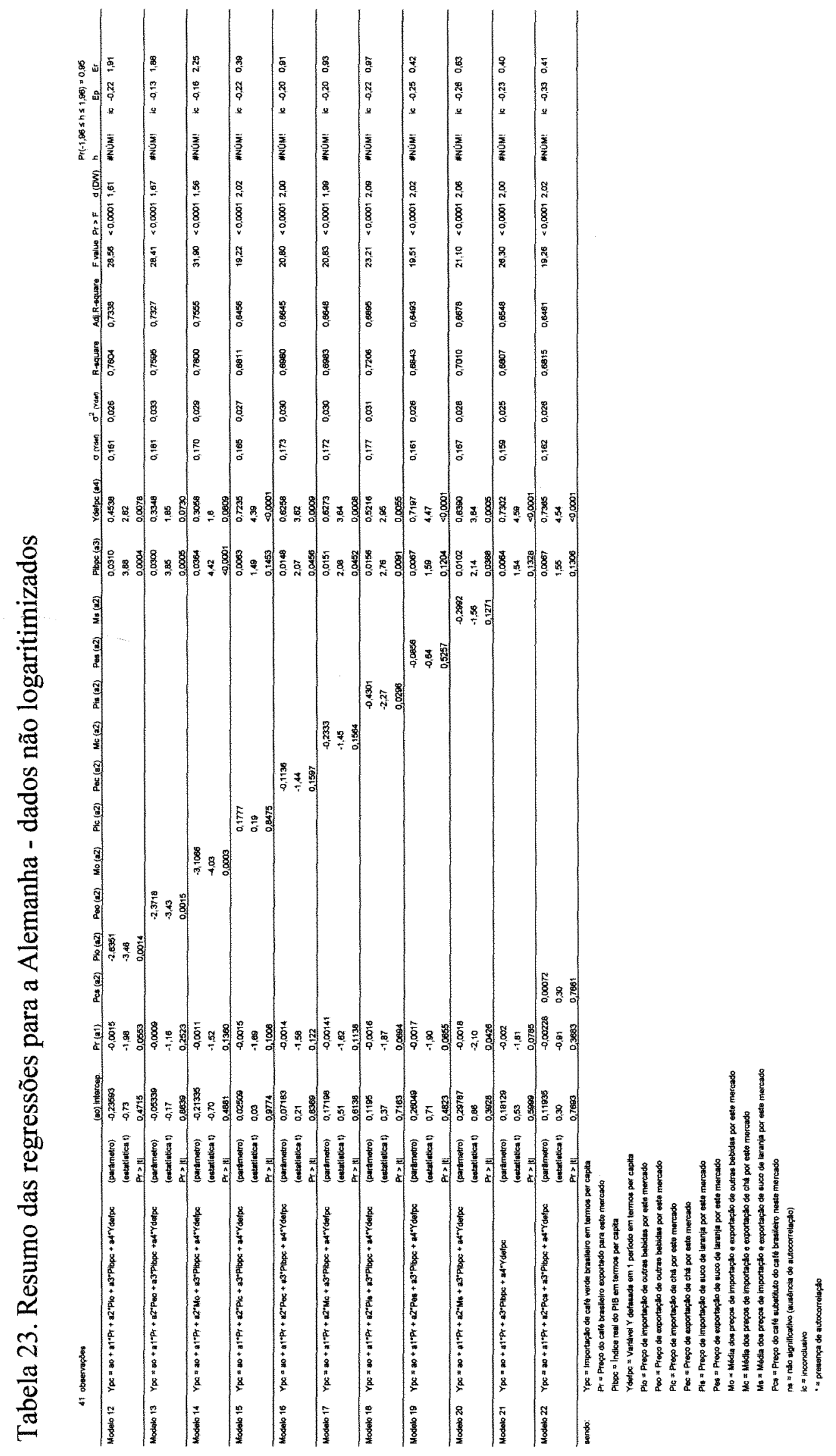




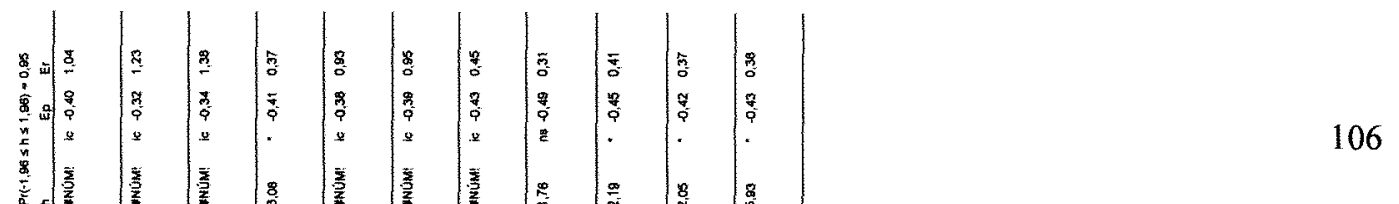

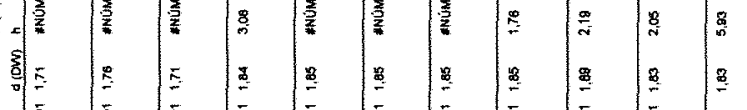

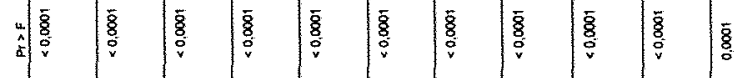

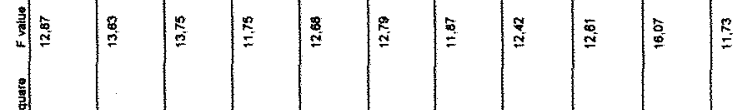

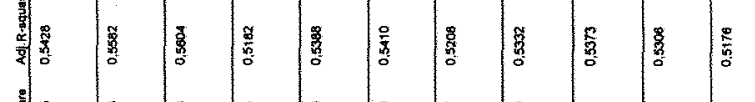

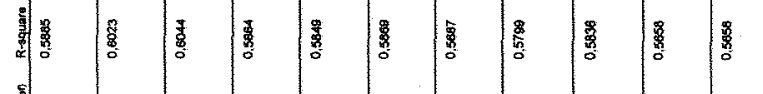

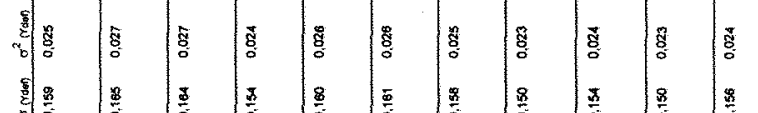

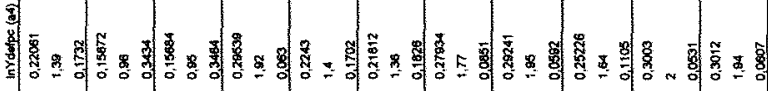

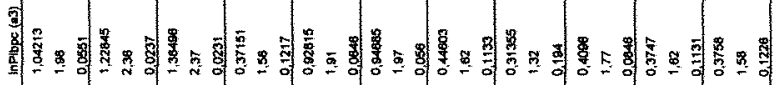

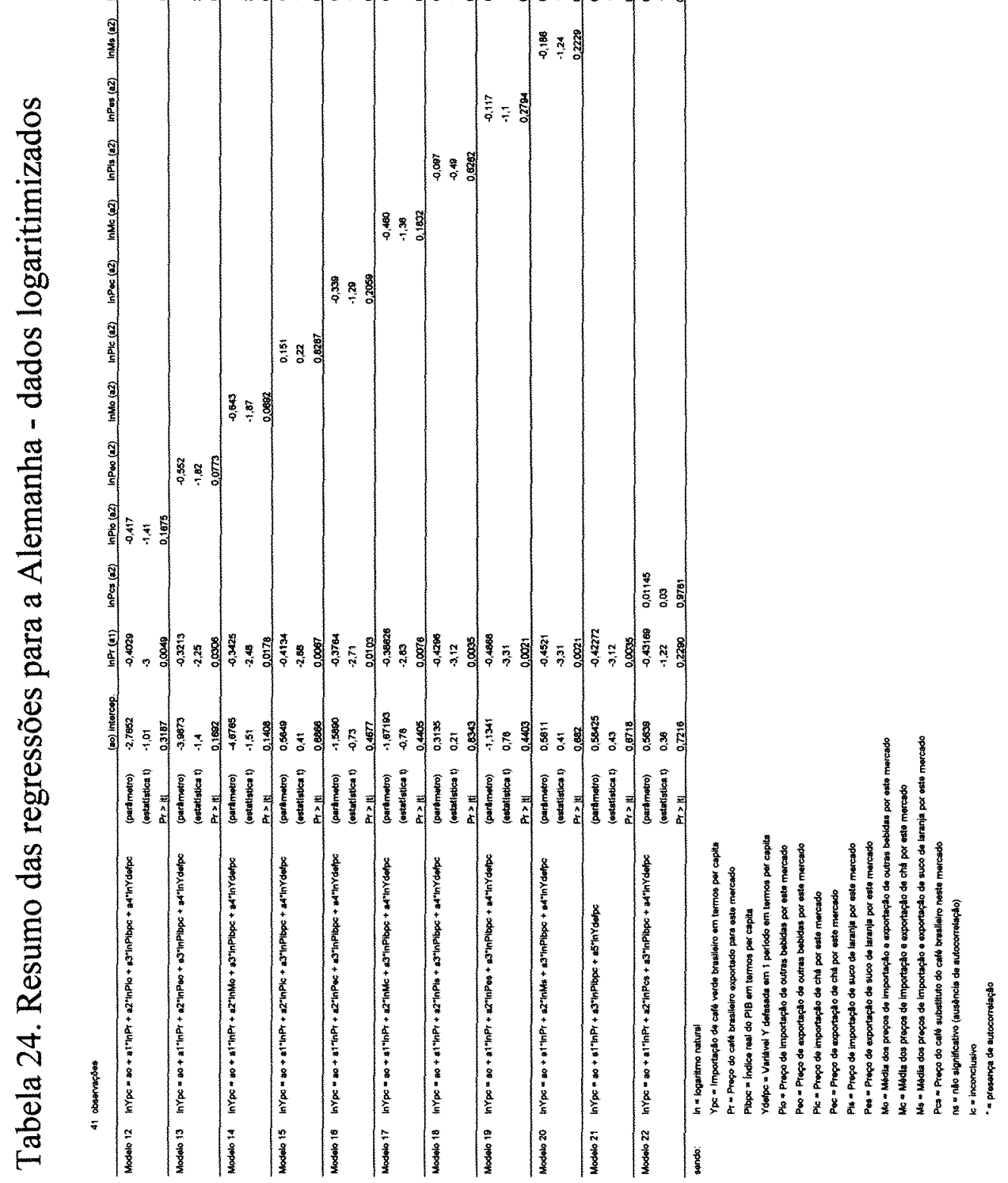




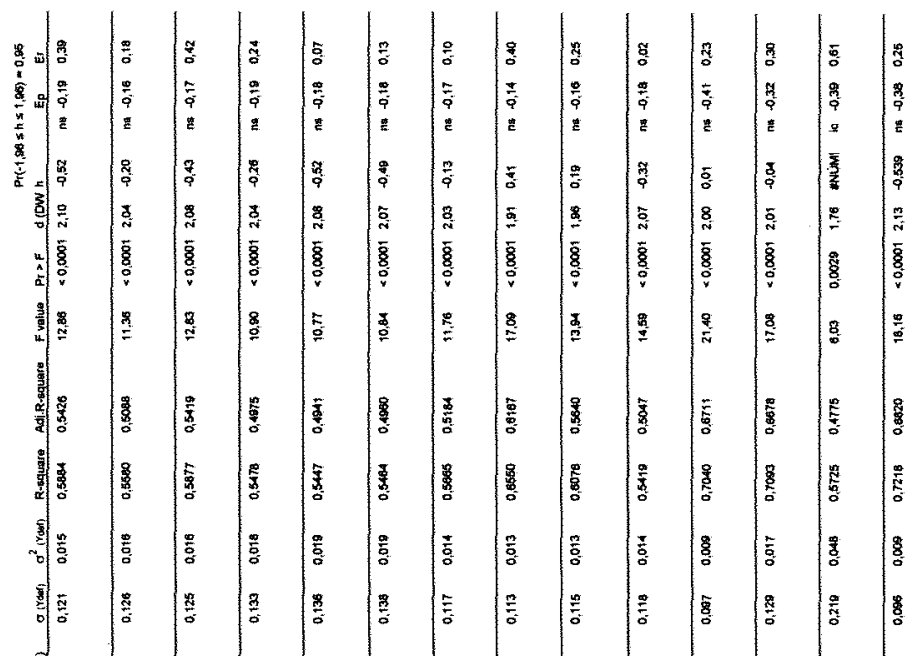

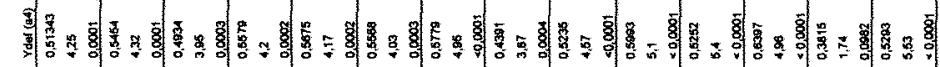

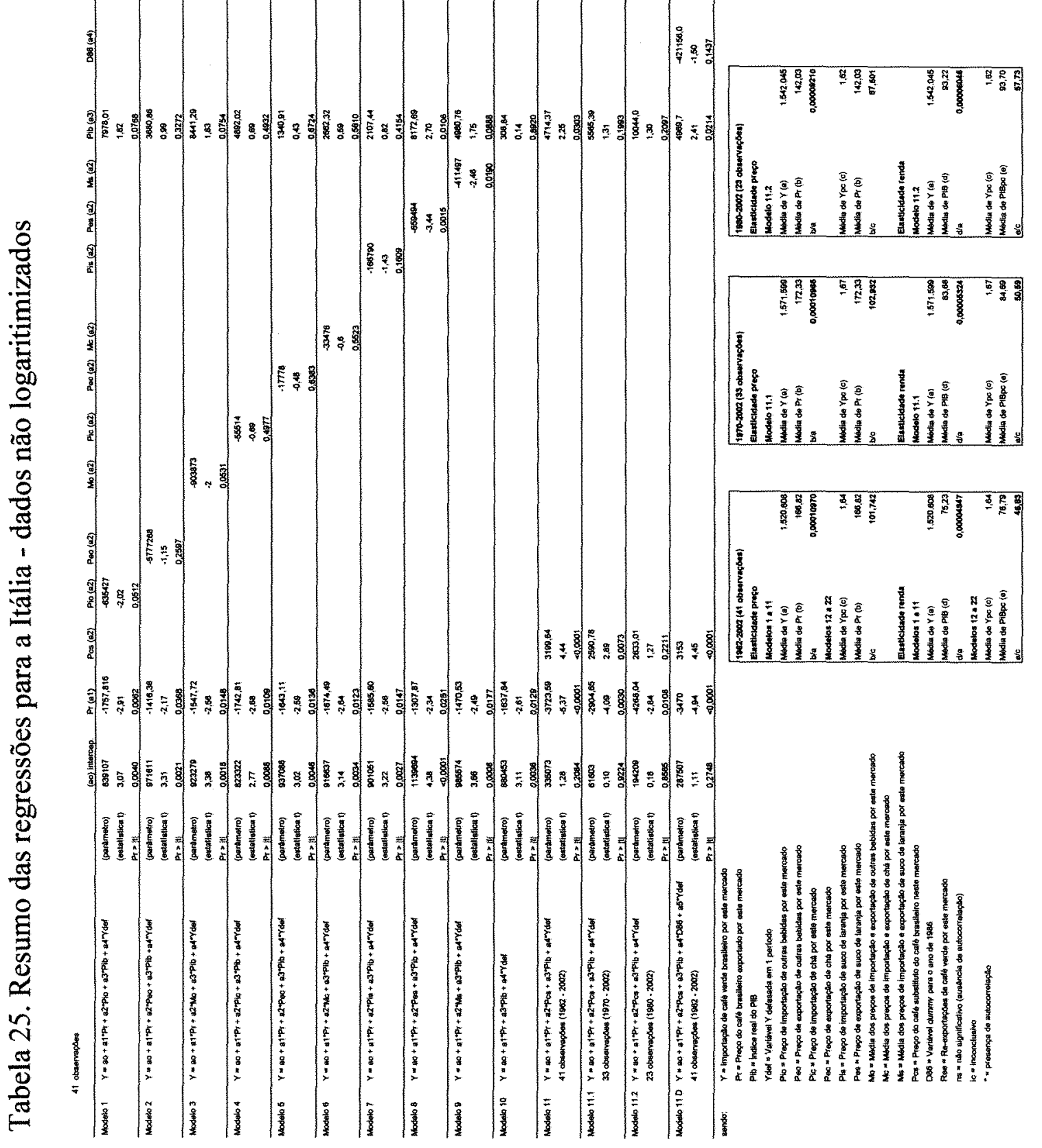



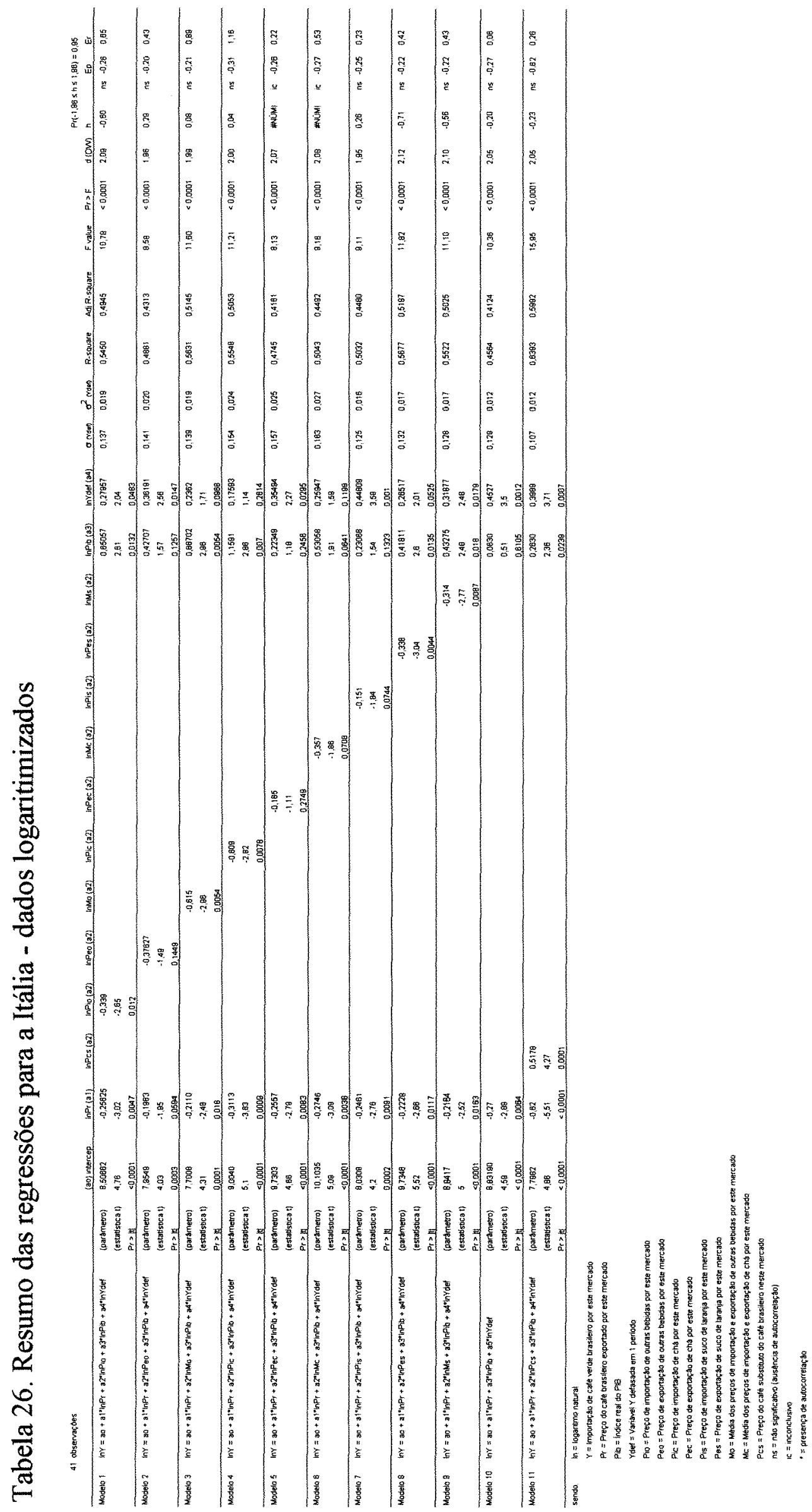


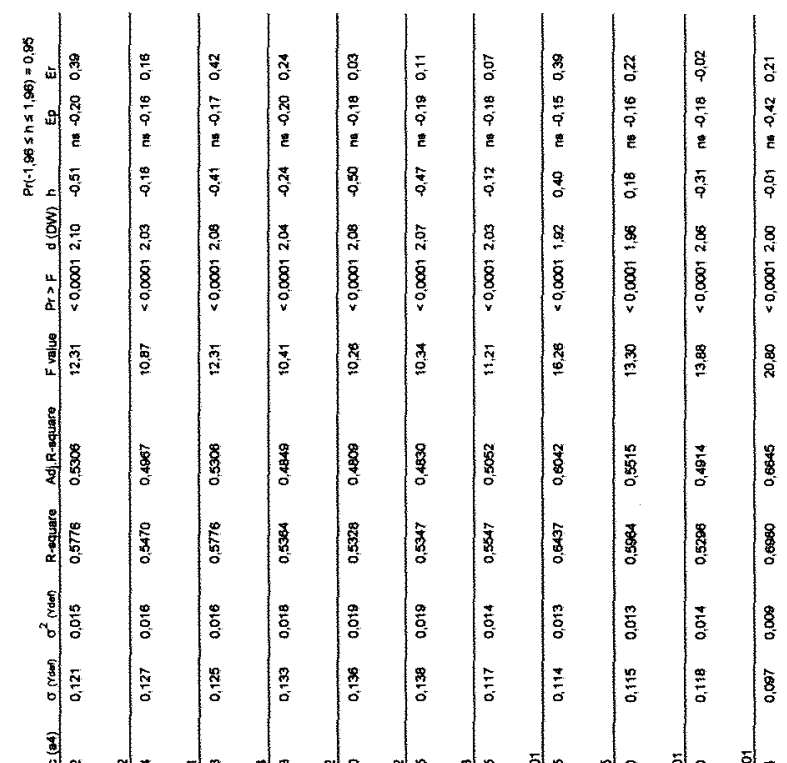

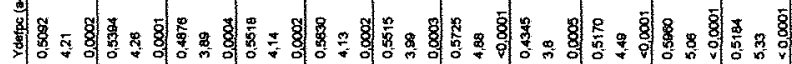

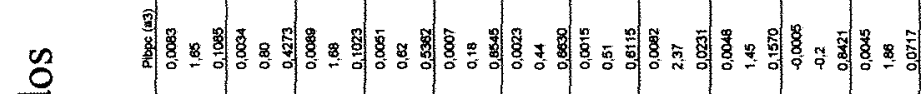

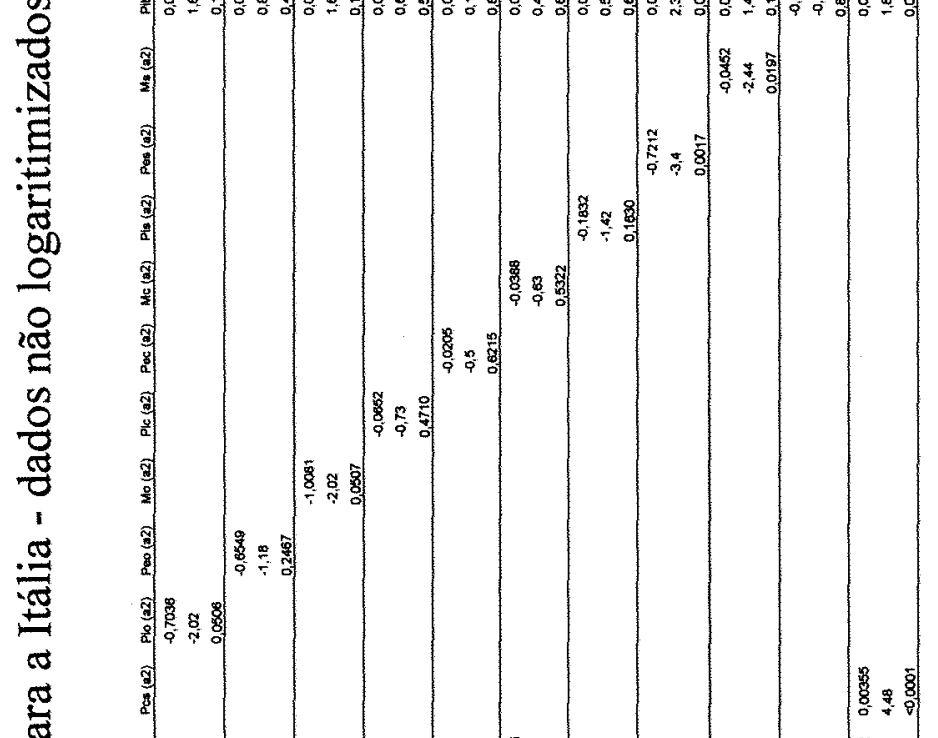

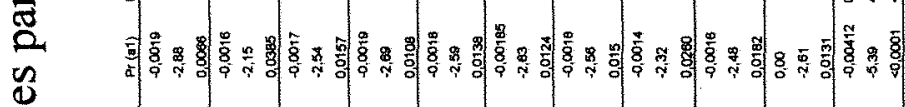

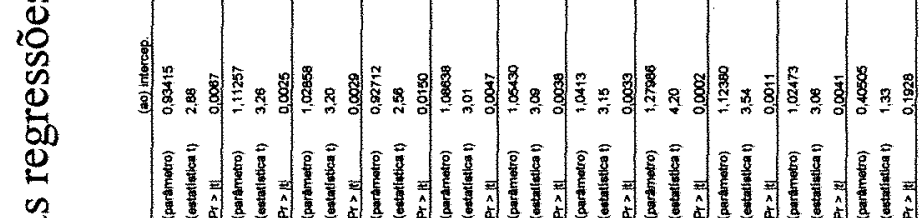

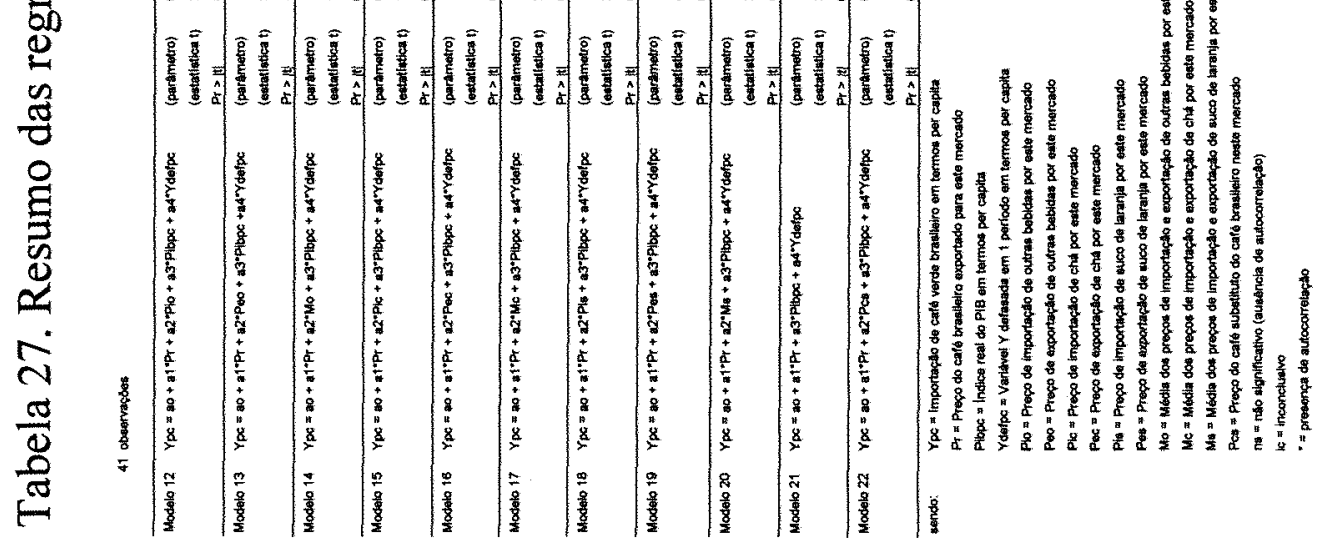




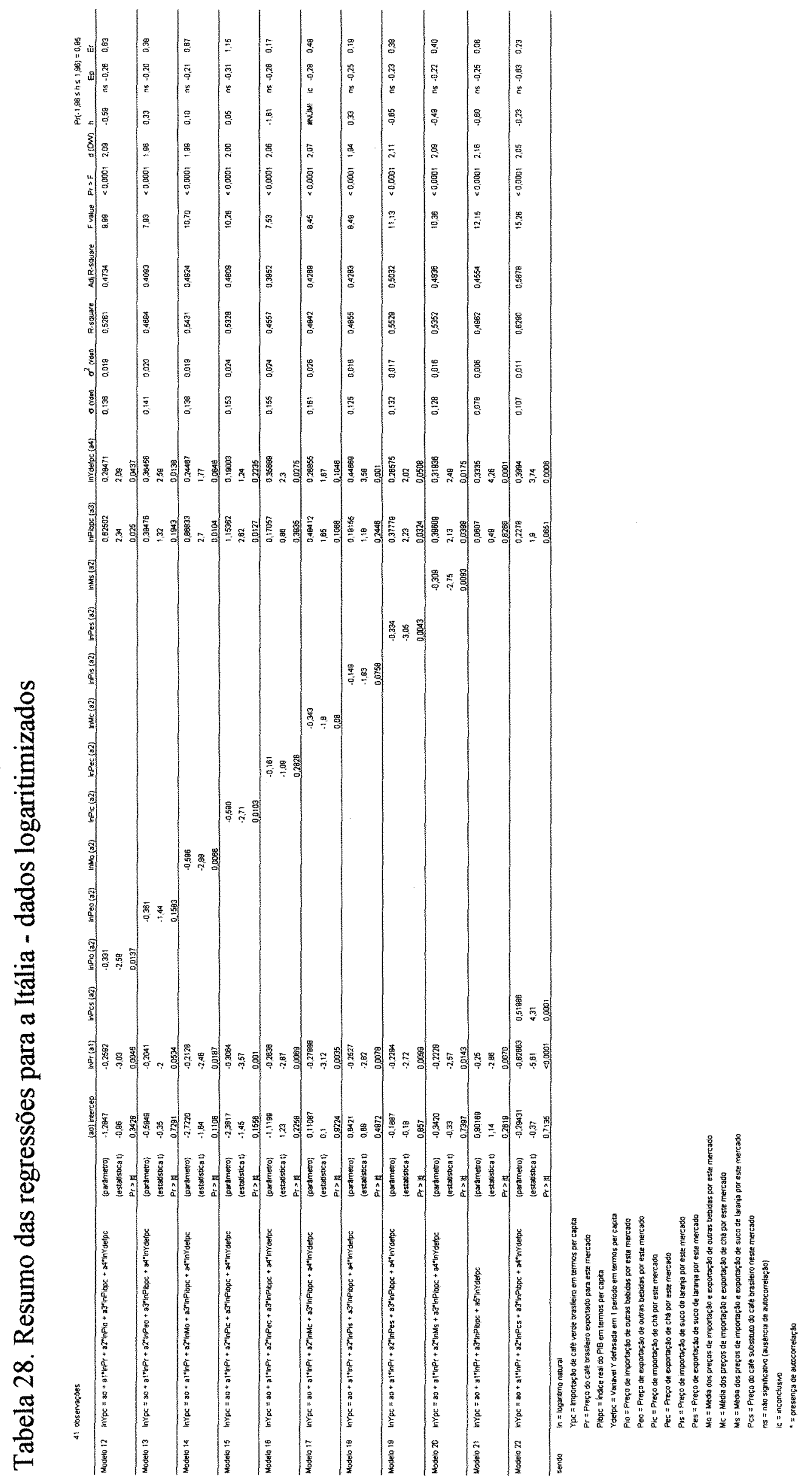




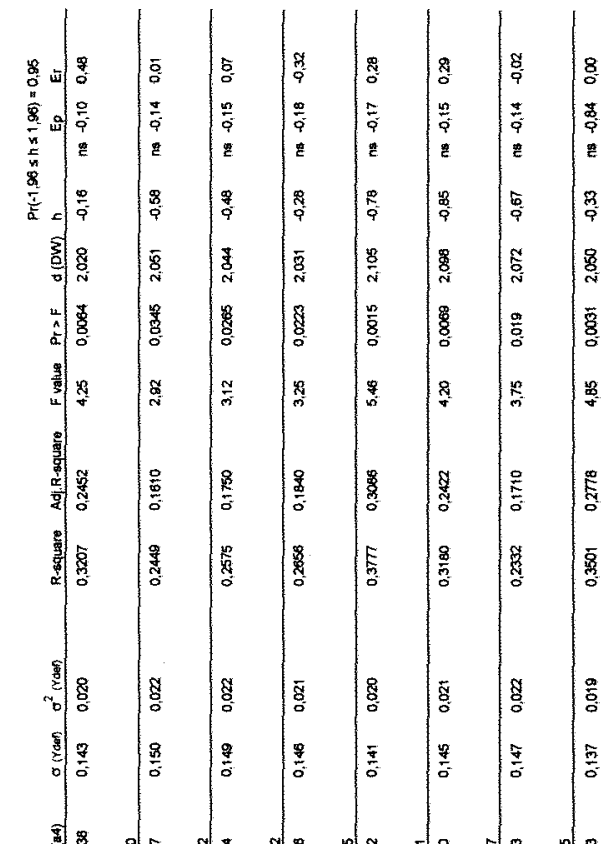

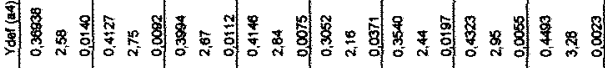

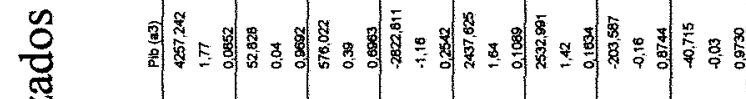

.

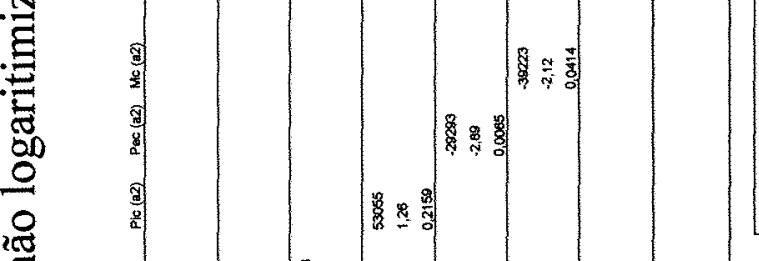

尊

(ำ

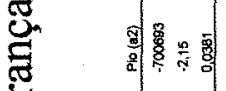

敨

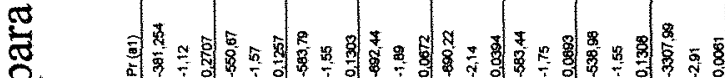

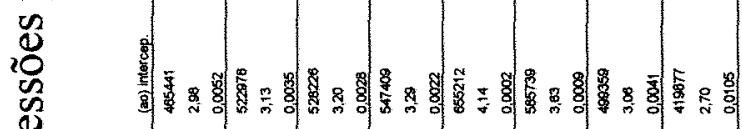

总

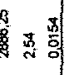
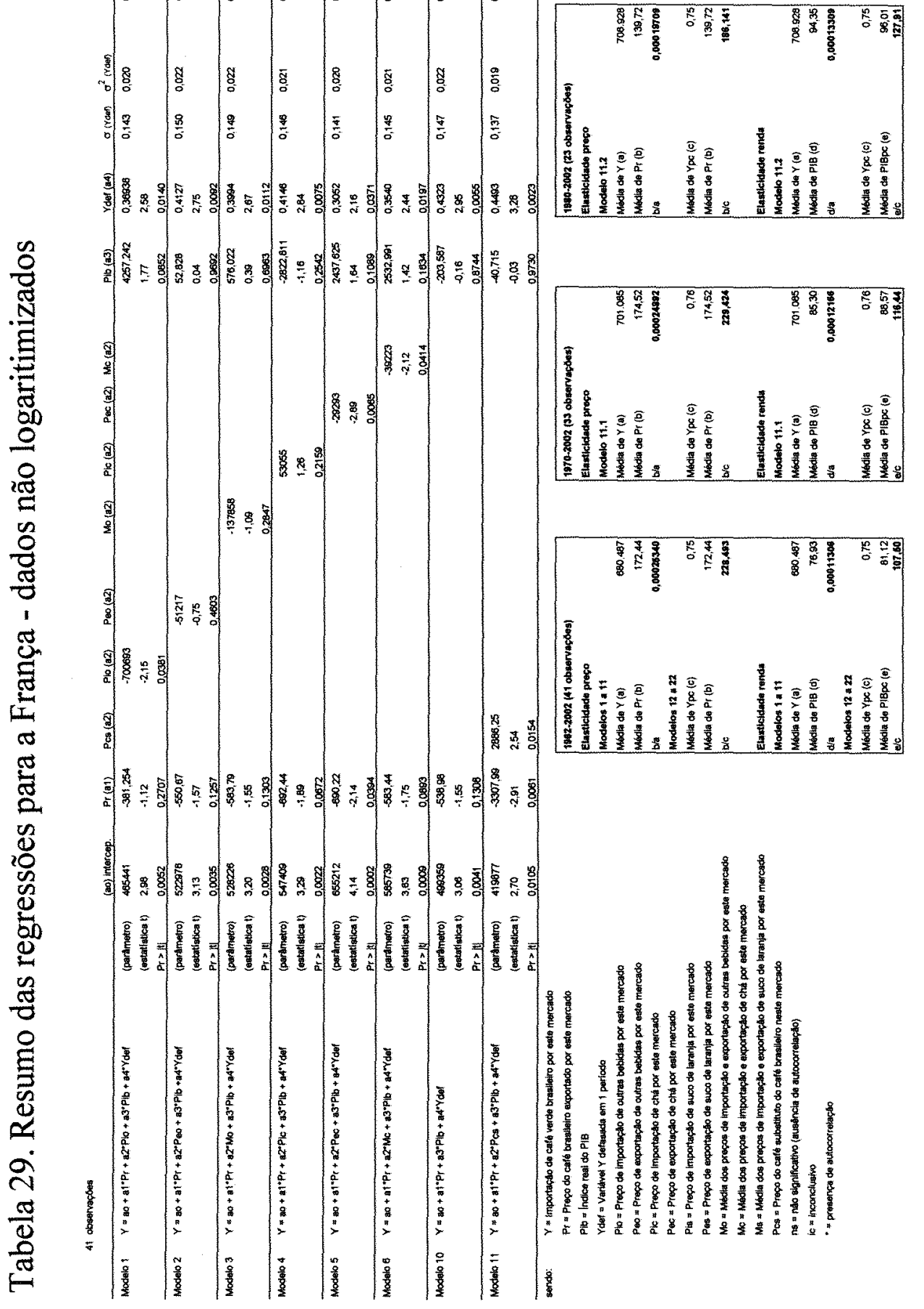

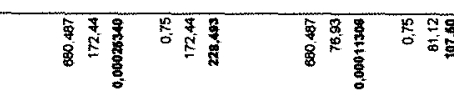

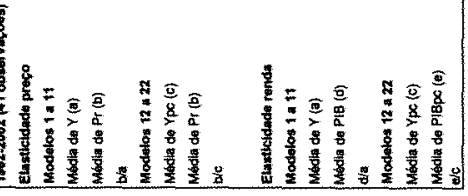




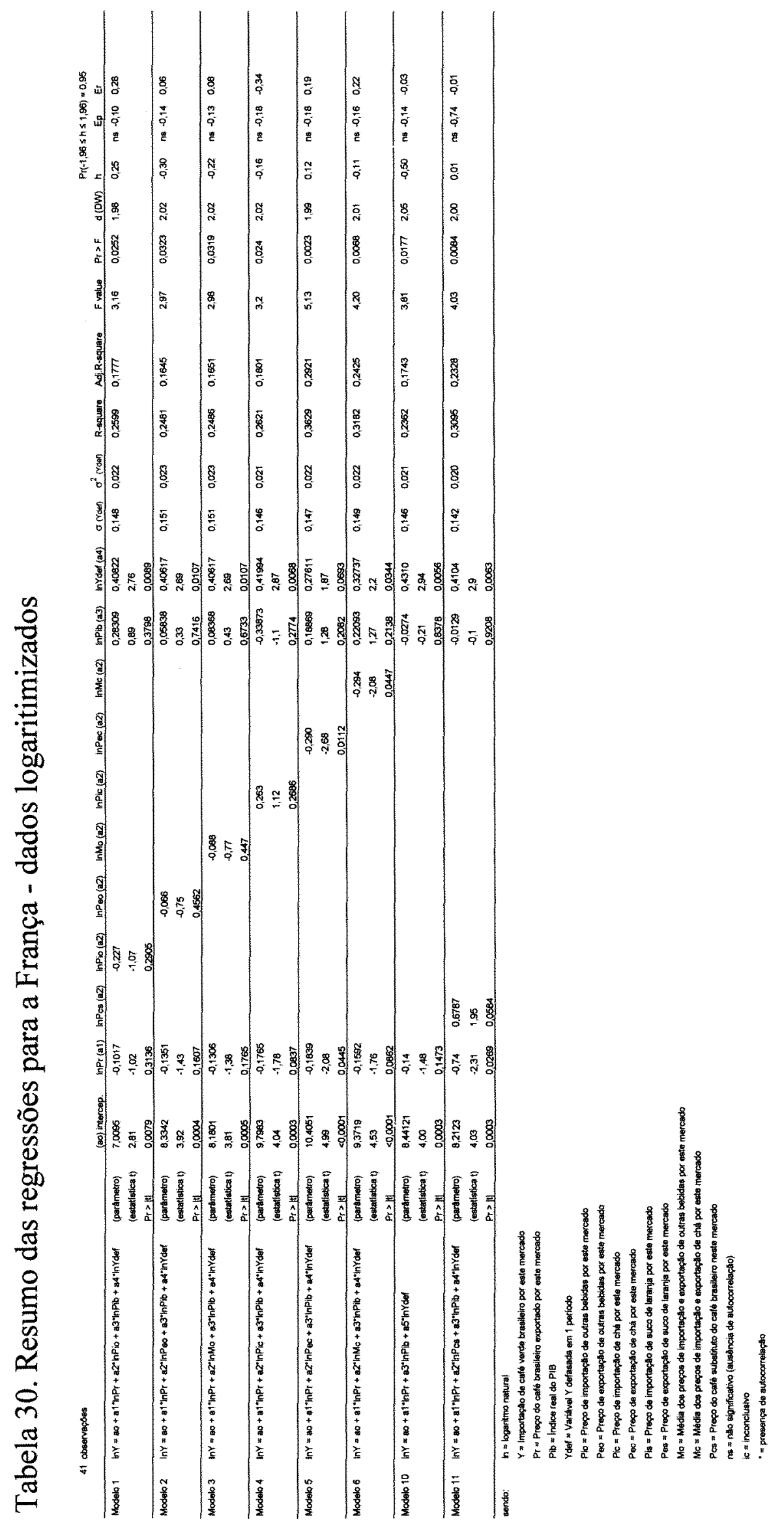


113

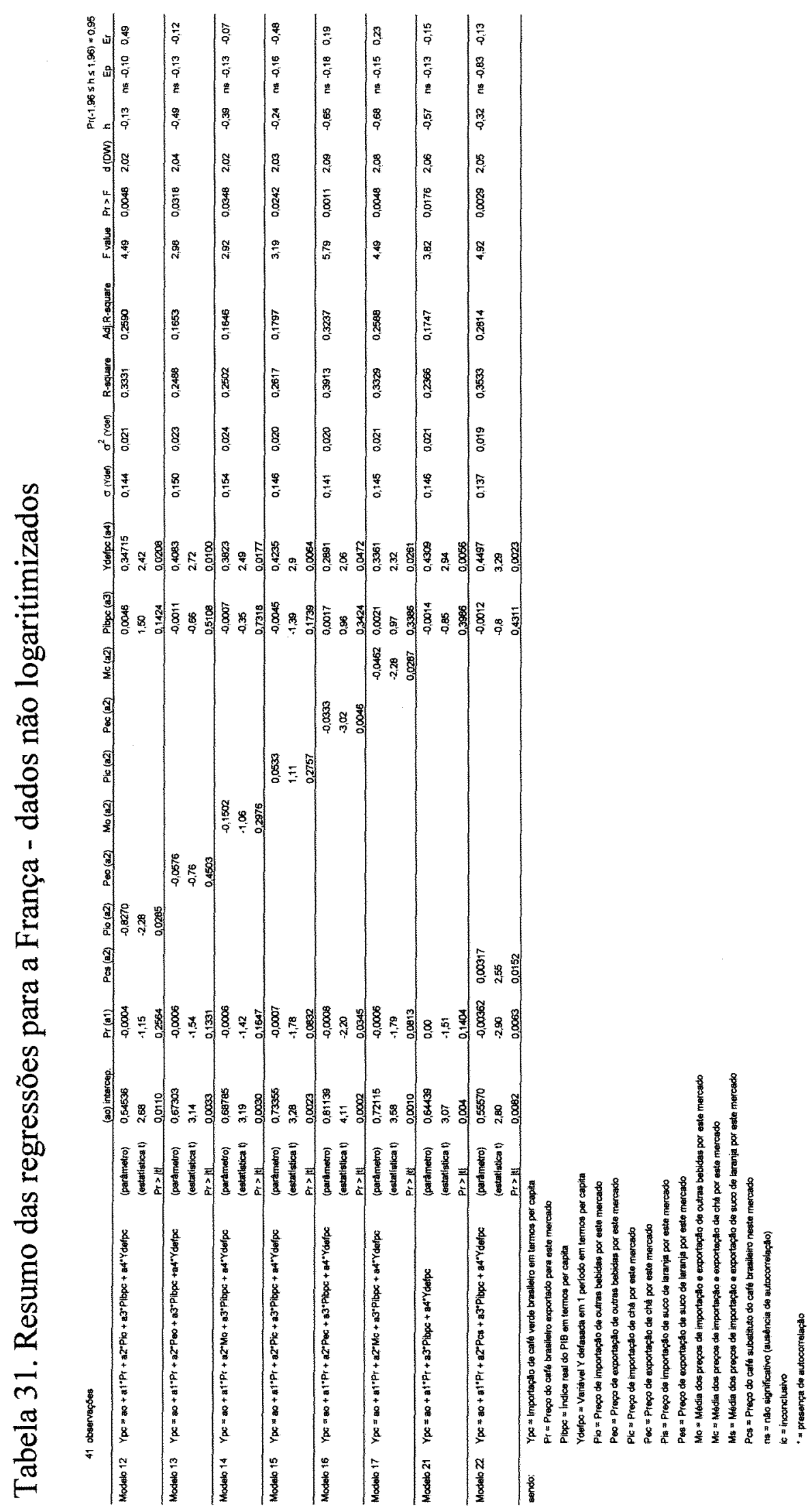




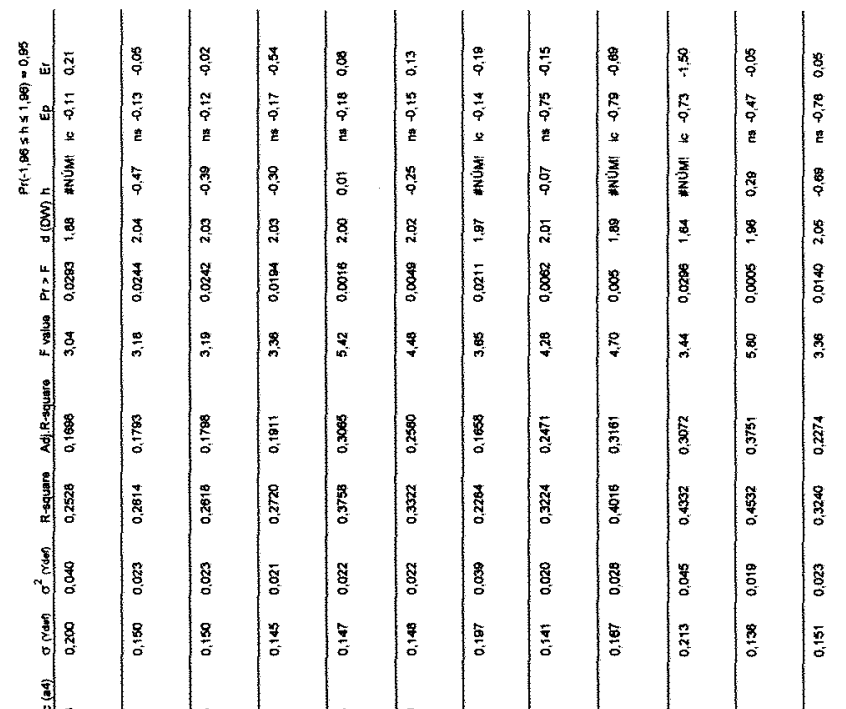

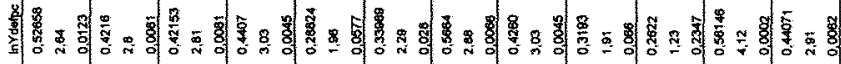

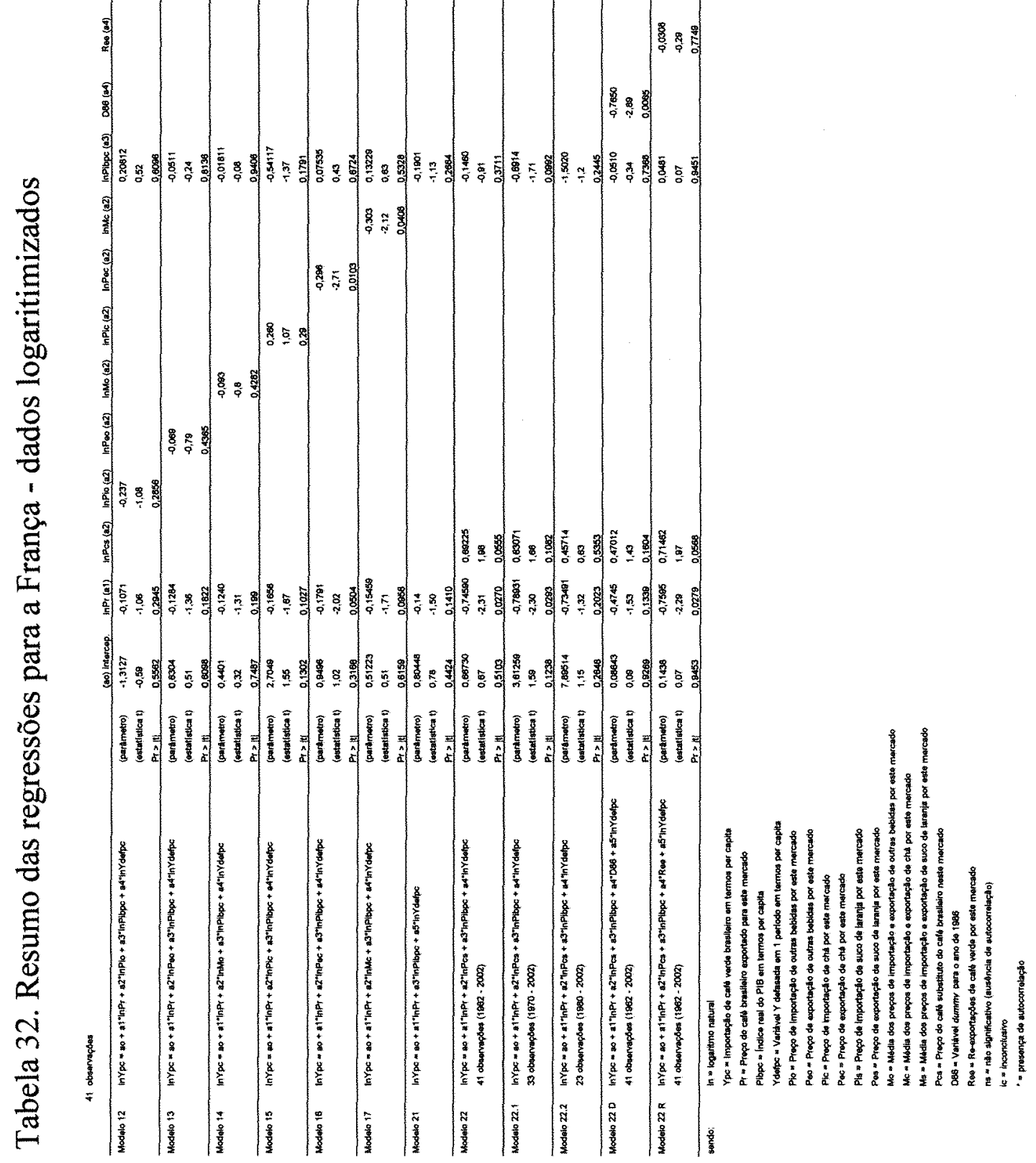




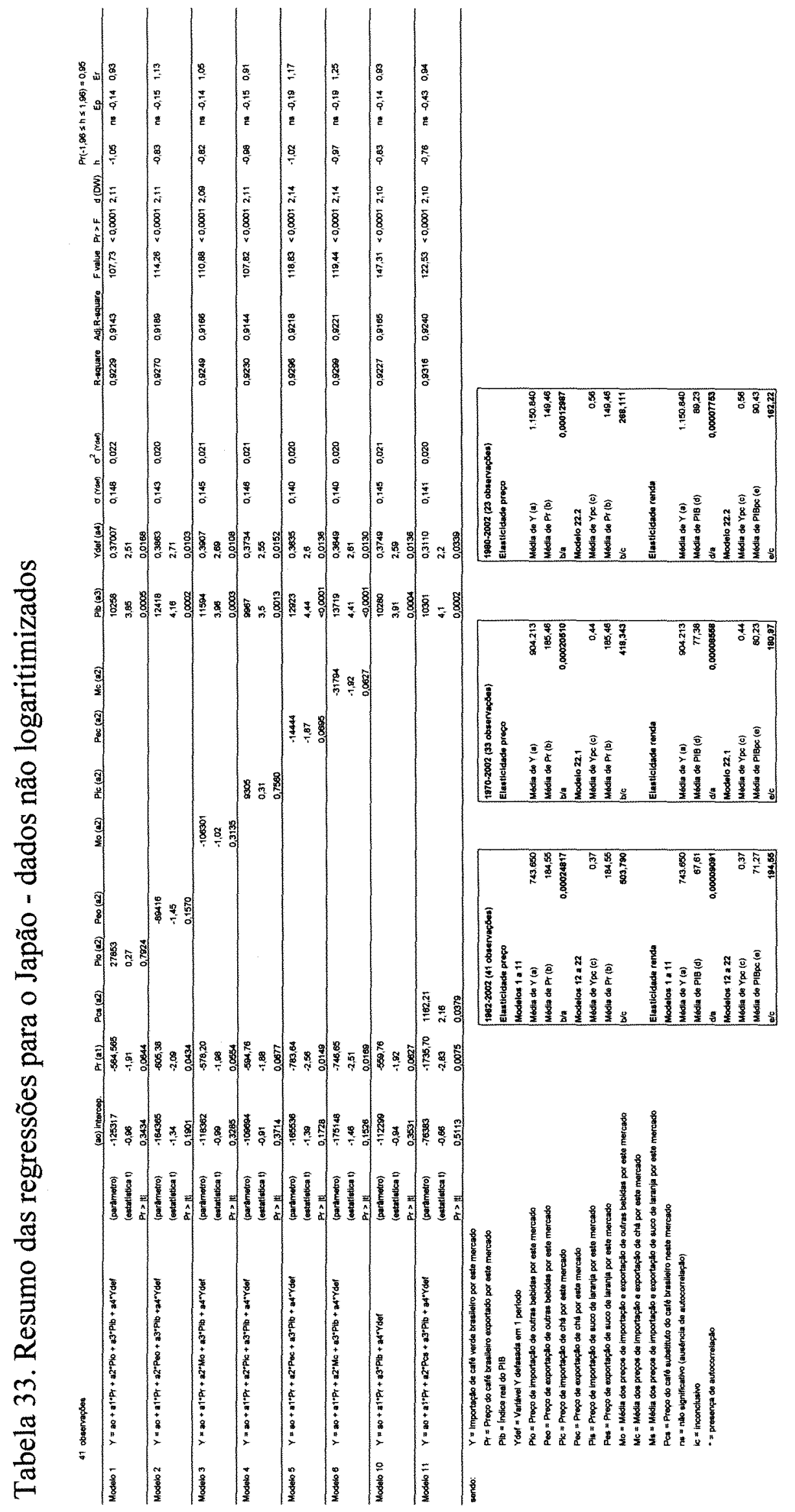

115 


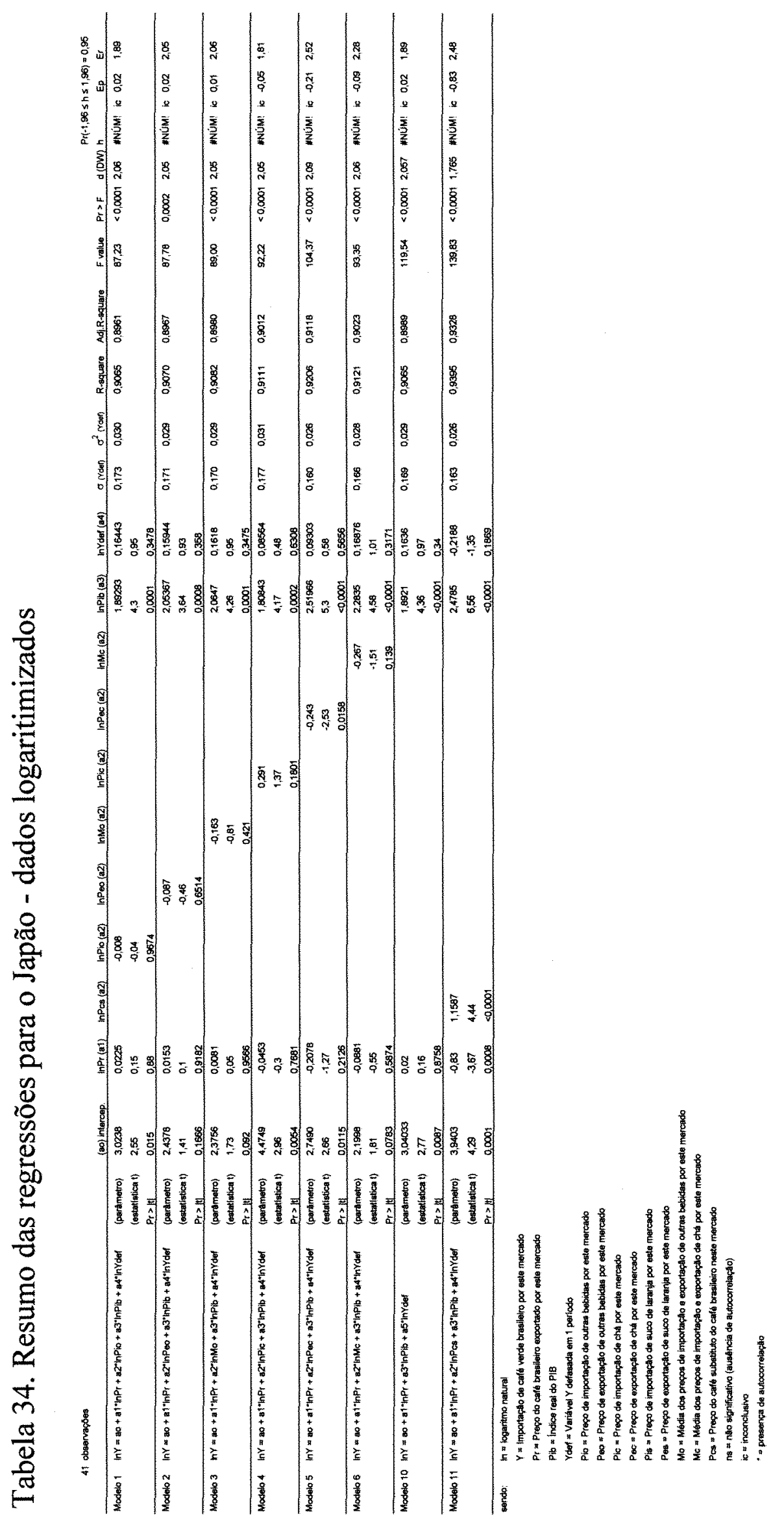




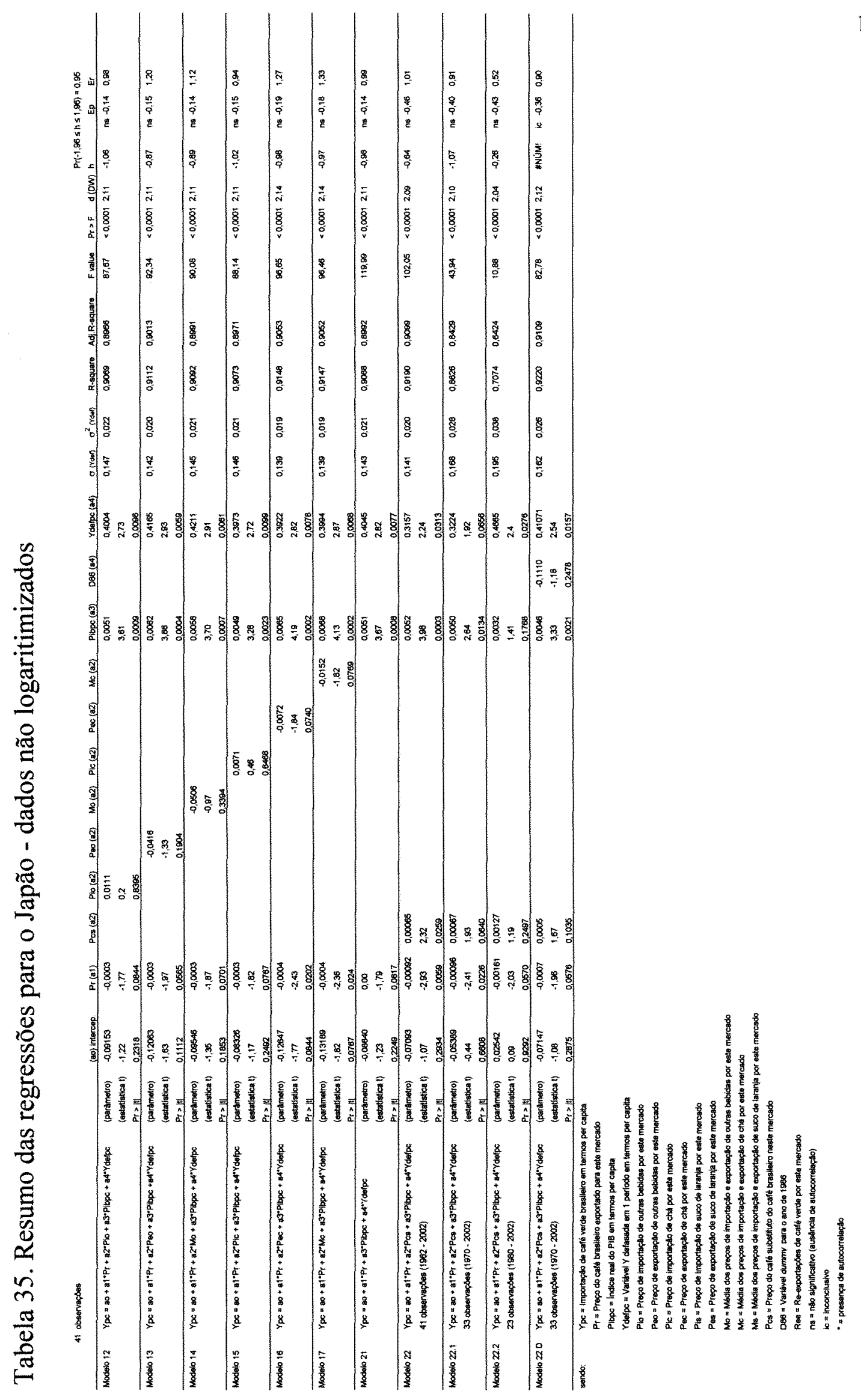




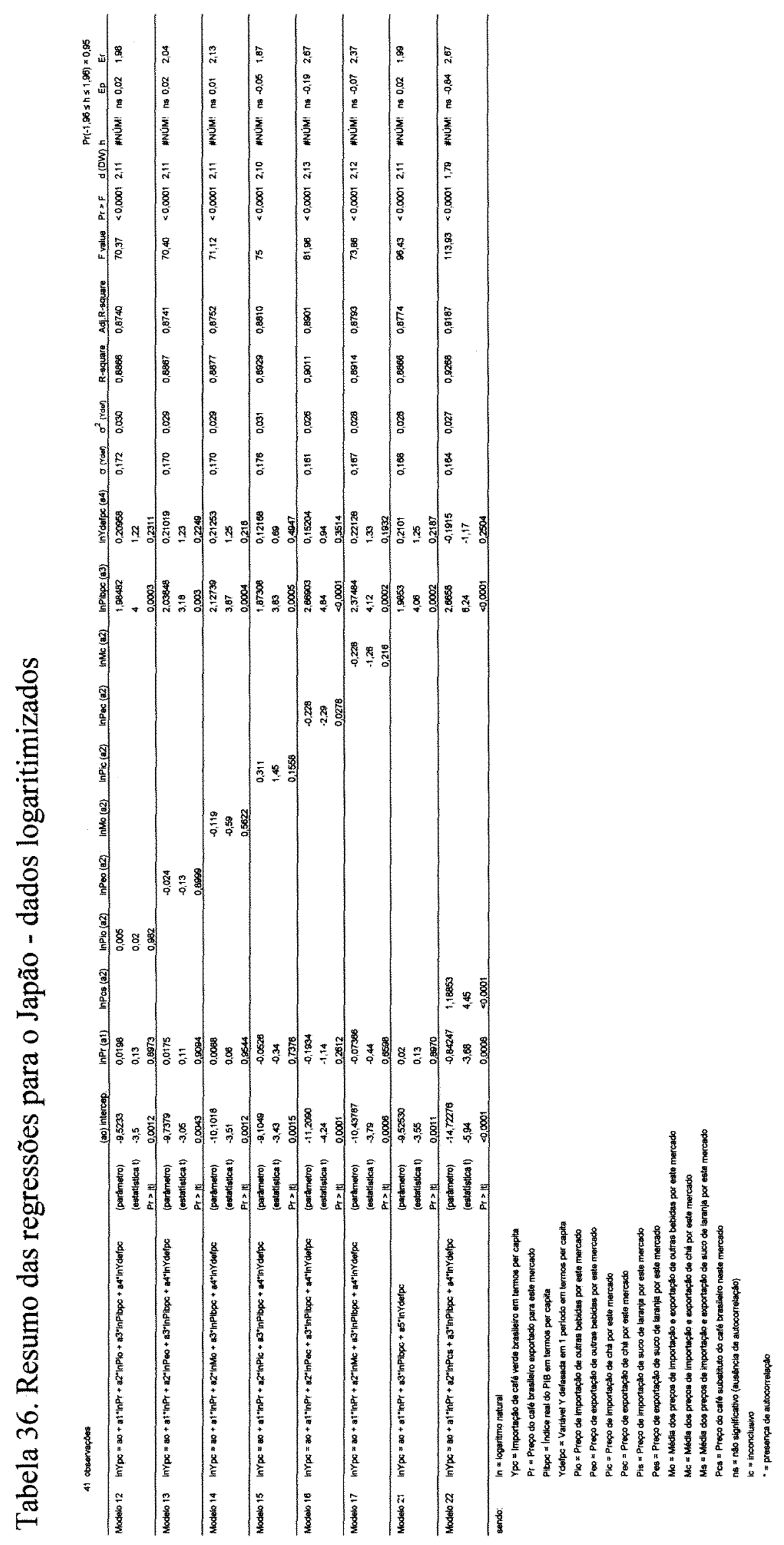




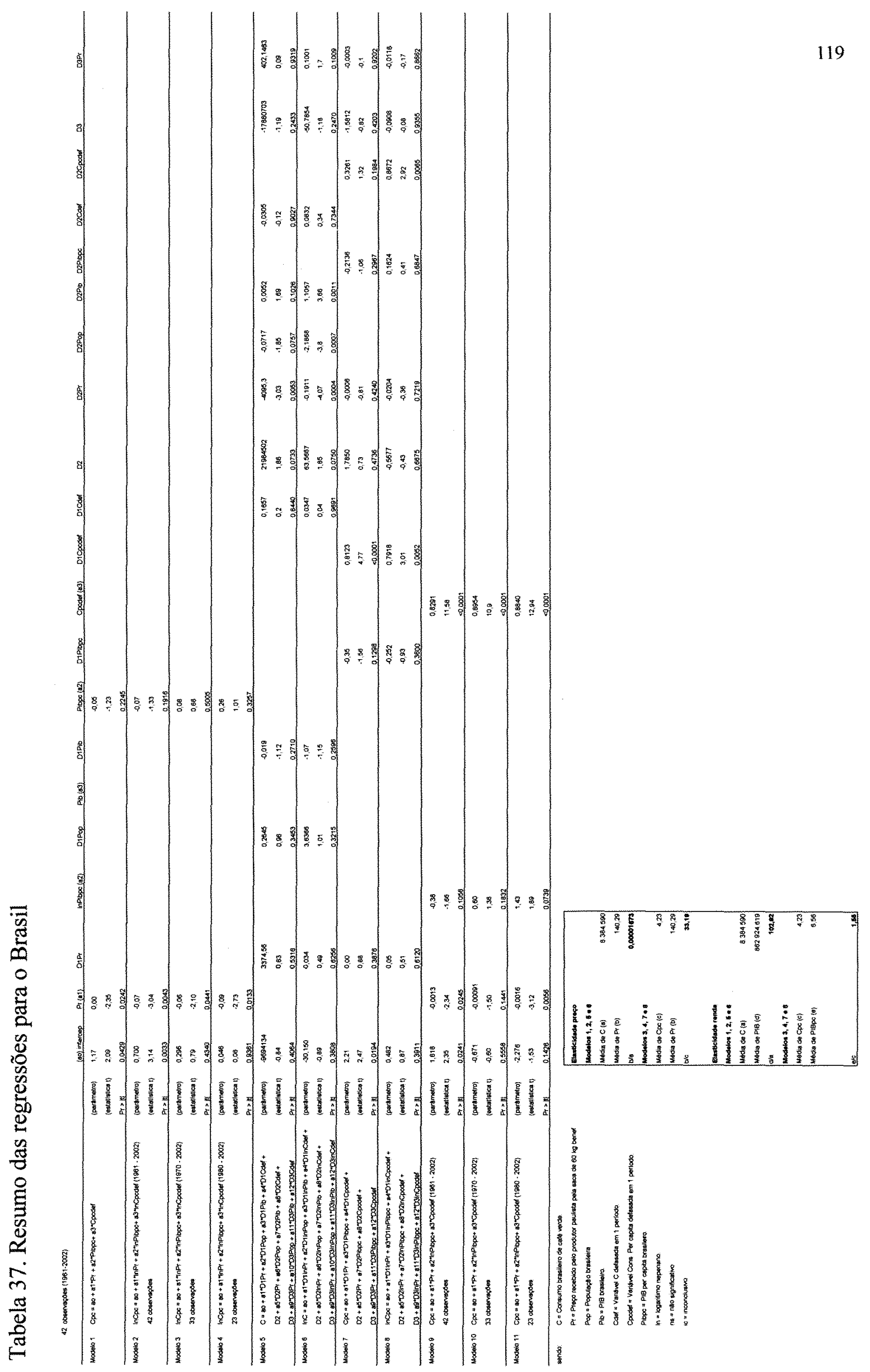




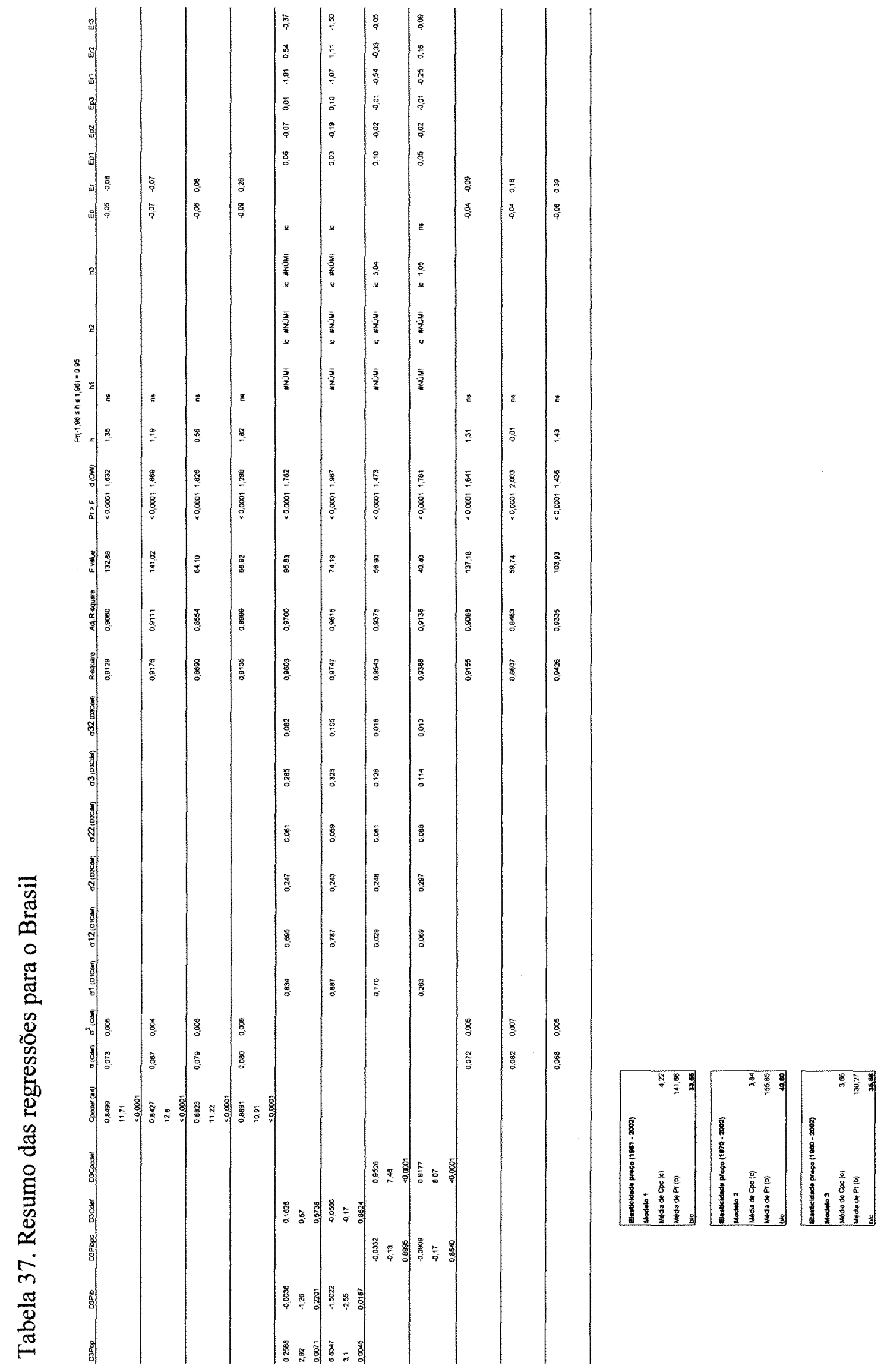




\section{REFERÊNCIAS BIBLIOGRÁFICAS}

ABAELU, J.N.; MANDERSCHEID, L.V. U.S. import demand for green coffee by variety. American Journal of Agricultural Economics, v.50, n.2, p.232-242, May 1968.

ALMEIDA, C.O. Política cambial e receita de exportações de café no Brasil - 1970 a 1989. Fortaleza, 1993. 66p. Dissertação (M.S) - Universidade Federal do Ceará.

ALVIM, F.H.B.; BACHA, C.J.C.; ALVES, C.C. Estimativa de uma equação de demanda de exportações brasileiras de café: período de 1980 a 2001. Revista de Economia e Agronegócio, v.1, n.4, p.441-459, out./dez. 2003.

ASSOCIAÇÃO BRASILEIRA DA INDÚSTRIA DE CAFÉ. Estatísticas. http://www.abic.com.br/estatisticas.html (09 mar. 2003)

BARBOSA, F. Microeconomia: teoria, modelos econométricos e aplicações à teoria brasileira. Rio de Janeiro: IPEA/INPES, 1985. 534p.

BRASIL. Ministério do Desenvolvimento, Indústria e Comércio Exterior. Sistema Alice. http://aliceweb.desenvolvimento.gov.br/ (15 jul. 2003)

CARVALHO, M.R. Análise estrutural da demanda interna de café. Viçosa, 1974. 135p. Dissertação (M.S) - Universidade Federal de Viçosa. 
COFFEE BUSINESS. Boletim diário. http://www.coffeebusiness.com.br (16 abr. 2003)

COSTA, S.L. da; SILVA, O.M. da. Café: condicionantes e elasticidades da demanda de consumo interno (compact disc). In: CONGRESSO BRASILEIRO DE ECONOMIA E SOCIOLOGIA RURAL, 41., Juiz de Fora, 2003. Anais. Brasília: SOBER, 2003.

DALY, R.F. Coffee consumption and prices in the United States. Agricultural Economics Research, v.10, n.3, p.61-71, July 1958.

DELFIM NETTO, A. Observações sobre o conceito de elasticidade. Revista dos Mercados, v.6, n.55, p.7-11, mar. 1955.

DELFIM NETTO, A. O problema da elasticidade da procura. In: INSTITUTO BRASILEIRO DO CAFÉ. Curso de economia cafeeira. Rio de Janeiro, 1962. p.672714.

DELFIM NETTO, A.; PINTO, C.A.A. O café do Brasil: vinte anos de substituição no mercado internacional. São Paulo, 1965. 724p. (Estudos ANPES, 3)

FAO. Statistical databases. http://www.fao.org/waicent/portal/statistics_en.asp (25 Aug. 2003)

FINAGEIV, V. Análise econométrica da demanda de exportação do café brasileiro. Viçosa, 1976. 24p. Dissertação (M.S) - Universidade Federal de Viçosa.

GUJARATI, D.N. Econometria básica. São Paulo: Makron Books, 2000. 846p.

HOPP, H.; FOOTE, R.J. A statistical analysis of factors that affect prices of coffee. Journal of Farm Economics, v.37, n.3, p.429-438, Aug. 1955. 
INSTITUTO BRASILEIRO DO CAFÉ (IBC). Rio de Janeiro, 1964-1989.

INSTITUTO DE PESQUISAS ECONÔMICAS APLICADAS. Estatísticas. http://www.ipeadata.gov.br/ (20 ago. 2003)

KINGSTON, J. A lei estatística da demanda do café. Rio de Janeiro: Ministério da Agricultura, 1939. 16p.

MARQUES, S.A. O consumo de café no Brasil, 1960-1981. São Paulo, 1984. 129p. Dissertação (M.S) - Faculdade de Economia e Administração - Universidade de São Paulo.

MESQUITA, J.M.C. de. Mercado de café: variáveis que influenciam o preço pago ao produtor. Ciência e Agrotecnologia, v.24, n.2, p.379-386, 2000.

PANIAGO, E. Café: produção, ciclo e procura. Experientiae, v.3, n.1, p.1-4, jan. 1963.

SAES, M.S.M.; FARINA, E.M.M. O agribusiness do café no Brasil. São Paulo: PENSA/Editora Milkbizz, 1999.218p.

SILVA, E.K. da.; MAIA, S.A. As exportações brasileiras de café (1961-2001): uma análise usando vetores auto-regressivos (VAR) (compact disc). In: CONGRESSO BRASILEIRO DE ECONOMIA E SOCIOLOGIA, 41., Juiz de Fora, 2003. Anais. Brasília: SOBER, 2003.

TAMAKI, T.; LARSON, D.W. Demanda de café em sete países selecionados. Revista de Economia e Sociologia Rural, v.20, n.3, p.465-477, jul./set. 1982.

UNITED STATES. Department of Agriculture. Tropical products: world markets and trade. http://www.fas.usda.gov/htp/tropical/2004/09-04/septtoc.htm (28 Oct. 2003) 
VIACAVA, C. Demanda de café brasileiro pelos EUA. Ensaios sobre café e desenvolvimento econômico. Rio de Janeiro: Instituto Brasileiro do Café, 1973. 578p.

VIANA, J.J.S.; SILVA, O.M. da; LIMA, J.E. de; CARVALHO, F.M.A. de. Diferenciação por origem na demanda internacional de cafés (comp act disc). In: CONGRESSO BRASILEIRO DE ECONOMIA E SOCIOLOGIA, 41., Juiz de Fora, 2003. Anais. Brasília: SOBER, 2003. 